\title{
GENERAL AND HOST-
}

\section{ASSOCIATED BACTERIAL INDICATORS OF FAECAL POLLUTION}

\author{
Valerie Harwood \\ University of South Florida \\ Tampa, United States \\ Orin Shanks \\ United States Environmental Protection Agency \\ Cincinnati, United States \\ Asja Korajkic \\ United States Environmental Protection Agency \\ Cincinnati, United States
}

\section{Matthew Verbyla}

San Diego State University

San Diego, United States

\section{Warish Ahmed}

Commonwealth Scientific and Industrial Research Organisation

Brisbane, Australia

\section{Mercedes Iriarte}

Universidad Mayor de San Simon

Cochabamba, Bolivia 


\section{Copyright:}

\section{cc) (1) (2) \\ BY SA}

This publication is available in Open Access under the Attribution-ShareAlike 3.0 IGO (CC-BY-SA 3.0 IGO) license (http://creativecommons.org/licenses/by-sa/3.0/igo). By using the content of this publication, the users accept to be bound by the terms of use of the UNESCO Open Access Repository (http://www.unesco.org/openaccess/terms-use-ccbysa-en).

\section{Disclaimer:}

The designations employed and the presentation of material throughout this publication do not imply the expression of any opinion whatsoever on the part of UNESCO concerning the legal status of any country, territory, city or area or of its authorities, or concerning the delimitation of its frontiers or boundaries. The ideas and opinions expressed in this publication are those of the authors; they are not necessarily those of UNESCO and do not commit the Organization.

\section{Citation:}

Harwood, V., Shanks, O., Koraijkic, A., Verbyla, M., Ahmed, W. and Iriate, M. (2017). General and host-associated bacterial indicators of faecal pollution. In: J.B. Rose and B. Jiménez-Cisneros, (eds) Water and Sanitation for the 21st Century: Health and Microbiological Aspects of Excreta and Wastewater Management (Global Water Pathogen Project). (A.Farnleitner, and A. Blanch (eds), Part 2: Indicators and Microbial Source Tracking Markers), Michigan State University, E. Lansing, MI, UNESCO.

https://doi.org/10.14321/waterpathogens.6

Acknowledgements: K.R.L. Young, Project Design editor; Website Design: Agroknow (http://www.agroknow.com)

Last published: February 19, 2018 


\section{Summary}

Faecal indicator bacteria (FIB) are used worldwide to warn of faecal and sewage contamination and associated human health risk due to an increased probability of the presence of waterborne pathogens. Ideally, FIB are nonpathogenic, and include bacteria such as thermotolerant (faecal) coliforms, Escherichia coli, enterococci, Bifidobacteria Bacteroidales, and Clostridium perfringens. These FIB are widely distributed in the faeces of humans, and most animals. Their levels in sewage and faeces are high enough that they can usually be detected when faecal contamination is present in surface waters. Current use of FIB in regulatory settings is reviewed in this chapter, as well as their ecology, persistence, and density in faeces, sewage, soil/sediments, biosolids and sewage sludge (primary and secondary). Furthermore, the benefits and limitations of using FIB as indicators of sewage and other faecal contamination in developed, developing, and emerging regions with a variety of climates are discussed.

Although FIB have served as useful sentinels of contaminated water for many decades, changing needs in water quality management and better understanding of FIB ecology have revealed several shortcomings, including extended persistence or replication in environmental habitats, and greater survival through wastewater treatment and disinfection systems than some pathogens. The ubiquitous distribution of FIB across different animal pollution sources, which is quite useful for assessing drinking water quality, becomes problematic for many surface water quality applications. The faecal pollution source frequently assumes a greater importance in contaminated surface waters because mitigation strategies and human health risk differ greatly depending upon the particular type of human and/or animal input involved. The field of microbial source tracking (MST) offers a diverse set of methodologies designed to identify human and other faecal contamination sources. This chapter discusses MST methods designed to identify bacteria that are associated with human waste, as well as methods targeting waste from ruminant, porcine, and avian animal groups. In addition, the roles of method standardization, data acceptance criteria, and emerging technologies are explored.

\subsection{Introduction to Faecal Indicator Bacteria and Host-Associated Bacteria}

Faecal indicator bacteria (FIB) are members of the microbial community of the gastrointestinal tract of most animals (including humans), and can be released into the environment in faeces, sewage, sludge, and other types of waste. The presence of FIB in environmental waters is a warning signal of faecal pollution, indicating the potential presence of pathogens. Ideally, FIB should not be pathogenic to minimize the health risk to analysts (e.g. WHO, 2004); however, some FIB groups are pathogenic (e.g. E. coli 0157:H7), and many are opportunistic pathogens, such as Enterococcus faecium (a member of the enterococci group). However, even high FIB levels do not always correspond to increased human health risk. FIB are members of bacterial groups or taxa that are ubiquitous in human and other animal faeces, and therefore provide little or no information about specific contamination source(s). In contrast, host-associated bacteria are closely linked to a particular animal group, and therefore can be used to indicate probable contamination sources, which is the basis of the emerging science field of microbial source tracking (MST). This chapter covers FIB and host-associated bacteria and their use for waste and water quality management. Faecal indicator organisms other than bacteria are covered in the chapters entitled "General and host-associated bacteriophage indicators of faecal pollution" and "Human and animal enteric viral markers for tracking the sources of faecal pollution"; while bacterial pathogens are covered in Part Three, Section II.

FIB are highly prevalent in the faeces of humans and most other animals and are easily enumerated by culture methods. High levels are considered to indicate faecal contamination; however, many of these bacteria can survive and even grow in permissive environments with elevated nutrients, shielding from sunlight, and low pressure from predation, e.g. sediments, compost, sewage sludge, biosolids, and soil (Solo-Gabriele et al., 2000; Zaleski et al., 2005). Decades of research have led to the realization that numerous shortcomings are associated with FIB, particularly for surface water quality assessment applications (Harwood et al., 2005).

The distribution of FIB in the gastrointestinal tract of many host species is, however, advantageous for a broad overview of faecal pollution levels in surface waters, and offers minimal impediments to the assessment of solid waste and wastewater treatment. FIB are useful for detecting breaches and inadequate treatment in drinking water distribution systems, as potable water should contain no FIB. However, their suitability for assessing surface water safety for recreational use can sometimes be confounded due to variable human health risks posed by the presence of non-human faecal sources (Soller et al., 2010 ; 2014). Furthermore, as FIB provide no information about a particular contamination source, they can have limited usefulness for preventing and remediating pollution inputs (Harwood et al., 2014). Host-associated faecal microorganisms, including bacteria, are used in MST applications to provide information about faecal pollution sources in water (i.e. human faeces versus the faeces of different animals).

The objectives of this chapter are to (i) briefly describe the taxonomy, physiology, and ecology of FIB and hostassociated bacteria, (ii) review the occurrence and persistence of these bacteria in faeces, wastewater, and sewage sludge, (iii) provide an overview of detection and quantification methods, and (iv) discuss future directions for their use in practice and regulatory settings.

\subsection{Description and Taxonomy of Faecal Indicator Bacteria}

FIB are a taxonomically and phylogenetically heterogeneous collection of microorganisms which are defined by characteristics that allow for their selective 
detection and quantification. Total coliforms, thermotolerant (faecal) coliforms, E. coli, and enterococci are used routinely for regulatory purposes throughout the world. Some of the methods approved by regulatory agencies and other standardizing bodies, e.g. the American Public Health Association (Standard Methods), the United States Environmental Protection Agency, and the International Organization for Standardization (ISO) are shown in Table 1. Tables 2 and 3 contain FIB water quality regulations in various water types based from many countries and organisations, including the European Union, the United States, and the World Health Organization. Several genera of strictly anaerobic faecal bacteria (Bacteroides, Bifidobacterium, and Clostridium) are also inhabitants of the gastrointestinal tract of humans and other warm-blooded animals, and they each have certain characteristics that make them useful indicators of faecal contamination as well.

Table 1. Summary of methods for detecting and quantifying general faecal indicator bacteria

\begin{tabular}{|c|c|c|c|c|}
\hline $\begin{array}{l}\text { Target Organism } \\
\text { or } \\
\text { Group of } \\
\text { Organisms }\end{array}$ & Identifiers & Method Type & $\begin{array}{c}\text { Examples of } \\
\text { Standardized Methods } \\
\text { and Test Kits }\end{array}$ & References \\
\hline Total coliforms & $\begin{array}{c}\text { Growth at } 35 \pm 0.5^{\circ} \mathrm{C} \\
\text { Lactose fermentation } \\
\text { Acid production } \\
\text { Negative oxidase enzyme } \\
\text { activity } \\
\text {-galactosidase enzyme } \\
\text { activity }\end{array}$ & $\begin{array}{c}\text { Presence/Absence } \\
\text { Most Probable Number }\end{array}$ & $\begin{array}{c}\text { Standard Methods 0221B; } \\
\text { IDEXX Colilert and Quanti- } \\
\text { Tray }\end{array}$ & APHA, 2012 \\
\hline Total coliforms & $\begin{array}{c}\text { Growth at } 35 \pm 0.5^{\circ} \mathrm{C} \\
\text { Lactose fermentation } \\
\text { Acid production } \\
\text { Negative oxidase enzyme } \\
\text { activity } \\
\text { B-galactosidase enzyme } \\
\text { activity }\end{array}$ & $\begin{array}{l}\text { Membrane Filtration } \\
\text { Colony Forming Units } \\
\text { (CFUs) }\end{array}$ & $\begin{array}{c}\text { Standard Methods 9222B, } \\
\text { 9222C; French Norm NF } \\
\text { T90-414 }\end{array}$ & $\begin{array}{l}\text { APHA, 2012; } \\
\text { AFNOR } 1985\end{array}$ \\
\hline $\begin{array}{l}\text { Thermotolerant } \\
\text { coliforms }\end{array}$ & $\begin{array}{c}\text { Growth at } 44.5 \pm 0.2^{\circ} \mathrm{C} \\
\text { Lactose fermentation } \\
\text { Acid production } \\
\text { Negative oxidase enzyme } \\
\text { activity } \\
\text { B-galactosidase enzyme } \\
\text { activity }\end{array}$ & $\begin{array}{c}\text { Presence/Absence } \\
\text { Most Probable Number }\end{array}$ & $\begin{array}{c}\text { Standard Methods 9221E; } \\
\text { IDEXX Colilert and Quanti- } \\
\text { Tray }\end{array}$ & APHA, 2012 \\
\hline $\begin{array}{l}\text { Thermotolerant } \\
\text { coliforms }\end{array}$ & $\begin{array}{c}\text { Growth at } 44.5 \pm 0.2^{\circ} \mathrm{C} \\
\text { Lactose fermentation } \\
\text { Acid production } \\
\text { Negative oxidase enzyme } \\
\text { activity } \\
\text { B-galactosidase enzyme } \\
\text { activity }\end{array}$ & $\begin{array}{l}\text { Membrane Filtration } \\
\text { Colony Forming Units } \\
\text { (CFUs) }\end{array}$ & $\begin{array}{c}\text { Standard Methods 9222D } \\
\text { and 9222E }\end{array}$ & APHA, 2012 \\
\hline E. coli & $\begin{array}{c}\text { Growth at } 44.5^{\circ} \mathrm{C} \\
\text { Lactose fermentation } \\
\text { Acid production } \\
\text { Negative oxidase enzyme } \\
\text { activity } \\
\text { B-glucuronidase enzyme } \\
\text { activity }\end{array}$ & $\begin{array}{c}\text { Presence/Absence } \\
\text { Most Probable Number }\end{array}$ & $\begin{array}{l}\text { ISO 9308-2, 9308-3; } \\
\text { IDEXX Colilert; Hach Kit } \\
\text { Method 8091; Aquagenx } \\
\text { Compartment Bag Test }\end{array}$ & $\begin{array}{c}\text { ISO, 1998; ISO, } \\
\text { 2012; } \\
\text { Stauber et al. } 2014\end{array}$ \\
\hline E. coli & $\begin{array}{c}\text { Growth at } 44.5^{\circ} \mathrm{C} \\
\text { Lactose fermentation } \\
\text { Acid production } \\
\text { Negative oxidase enzyme } \\
\text { activity } \\
\text { B-glucuronidase enzyme } \\
\text { activity }\end{array}$ & $\begin{array}{l}\text { Membrane Filtration } \\
\text { Colony Forming Units } \\
\text { (CFUs) }\end{array}$ & $\begin{array}{l}\text { US EPA Method 1603; ISO } \\
\text { 9308-1; Hach Kit (m- } \\
\text { ColiBlue24 broth) }\end{array}$ & $\begin{array}{l}\text { USEPA, 2006; } \\
\text { ISO, } 2014\end{array}$ \\
\hline E. coli & $\begin{array}{c}\text { Identification of uidA gene } \\
\text { via qPCR } \\
\text { Identification of the } \\
\text { EC1531 sequence via FISH }\end{array}$ & Molecular & $\mathrm{NRa}$ & $\begin{array}{c}\text { Chern et al., 2009; } \\
\text { Noble et al., 2010; } \\
\text { Langendijk et al. } \\
1995\end{array}$ \\
\hline
\end{tabular}


Enterococci and

Faecal streptococci

Enterococci and

Faecal streptococci

Enterococci and

Faecal streptococci

Bacteroides spp.

Bifidobacterium
spp.

Bifidobacterium spp.

\section{Clostridium spp.}

Clostridium spp.

Clostridium spp.
Growth in azide dextrose media within 48 hours $\beta$-D-glucosidase enzyme activity

Growth in azide dextrose media within 48 hours

$\beta$-D-glucosidase enzyme activity

Identification of the Enterola gene via qPCR

Identification of the Genbac3 gene via qPCR Identification of the sequence between primers Bac32F and Bac708R via endpoint PCR

Identification of colony forming units (CFUs) on BIM-25 media, YN-6, YN-1, Beerens, BFM or HBSA media.

Identification of the Bifidobacterium gene via qPCR

Identification of the BIF164 sequence via FISH

Chromogenic CP ChromoSelect Agar Identification of colony forming units (CFUs) on m-CP agar

Chromogenic CP ChromoSelect Agar Identification of colony forming units (CFUs) on $\mathrm{m}$-CP agar

Identification of the Cperf gene via qPCR

Identification of the HIS150 sequence via FISH

Culture (MPN)
Membrane Filtration

Colony Forming Units (CFUs)

Membrane Filtration

Colony Forming Units (CFUs)

Molecular

Molecular

Molecular

Presence/Absence Most Probable Number

Membrane Filtration Colony Forming Units (CFUs)

Molecular

ISO 7899-1

ISO, 1998

Standard Methods 9230B and 9230C; ISO 7899-2;

US EPA Method 1600

US EPA Methods 1609 and 1611

US EPA Method B, EPA-822-R-10-003

NR

NR

ISO 6461-1;

ISO 6461-2

NR
ISO, 1986

Sivaganesan et al., 2010;

ISO, 1998; USEPA, 2006; APHA, 2012

Ludwig and Schleifer 2000; Noble et al.; 2010

Bernhard and Field 2000; Dick and

Field , 2004

Mara and Oragui, 1983; Munoa and Pares, 1988;

Nebra and Blanch, 1999

Gueimonde et al., 2004;

Langendijk et al., 1995

ISO, 1986

Langendijk et al., 1995
Beerens, 1990;

${ }^{a}$ NR: Not reported

Table 2. Summary of general faecal indicator bacteria norms, regulations, and standards in wastewater, surface, recreational and marine waters

\begin{tabular}{|c|c|c|c|c|}
\hline Area & Regulatory Use & $\begin{array}{c}\text { Maximum Limit for Faecal Indicator } \\
\text { Bacteria }\end{array}$ & Guideline, Norm, or Standard & Reference \\
\hline Global & $\begin{array}{l}\text { Wastewater, } \\
\text { excreta, } \\
\text { greywater use in } \\
\text { agriculture and } \\
\text { aquaculture }\end{array}$ & $\begin{array}{l}\text { Does not specify a maximum limit for faecal } \\
\text { indicator bacteria; instead recommends the } \\
\text { use of microbial risk assessment }\end{array}$ & $\begin{array}{l}\text { World Health Organization } \\
\text { Guidelines for the Safe Use of } \\
\text { Wastewater, Excreta and } \\
\text { Greywater }\end{array}$ & WHO, 2006 \\
\hline
\end{tabular}




\begin{tabular}{|c|c|c|}
\hline Area & Regulatory Use & $\begin{array}{c}\text { Maximum Limit for Faecal Indicator } \\
\text { Bacteria }\end{array}$ \\
\hline Bolivia & $\begin{array}{c}\text { Effluent } \\
\text { discharge to the } \\
\text { environment }\end{array}$ & $\begin{array}{l}\text { Faecal coliforms: } \\
1000 \mathrm{MPN} / 100 \mathrm{~mL}\end{array}$ \\
\hline Brazil & $\begin{array}{c}\text { Domestic water } \\
\text { courses }\end{array}$ & $\begin{array}{c}\text { Class } 1 \text { Waters } \\
\text { (domestic use with little or no treatment): } \\
\text { Discharge of treated effluent not permitted } \\
\text { Class } 2 \text { Waters (domestic use after } \\
\text { conventional treatment; irrigation of } \\
\text { horticulture or fruiting plants; primary } \\
\text { contact recreation): } \\
\text { Total coliforms: }<5,000 / 100 \mathrm{~mL} \\
\text { in } 80 \% \text { of at least } 5 \text { monthly samples } \\
\text { Faecal coliforms: }<1,000 / 100 \mathrm{~mL} \\
\text { in } 80 \% \text { of at least } 5 \text { monthly samples } \\
\text { Class } 3 \text { Waters (domestic use after } \\
\text { conventional treatment; protection of fish } \\
\text { and other flora and fauna; use by wildlife for } \\
\text { drinking): } \\
\text { Total coliforms: }<20,000 / 100 \mathrm{~mL} \\
\text { in } 80 \% \text { of at least } 5 \text { monthly samples } \\
\text { Faecal coliforms: }<4,000 / 100 \mathrm{~mL} \\
\text { in } 80 \% \text { of at least } 5 \text { monthly samples } \\
\text { Class } 4 \text { Waters (domestic use after heavy } \\
\text { treatment; navigation; scenic purposes; } \\
\text { industrial use, irrigation and less demanding } \\
\text { uses): } \\
\text { No faecal indicator limits specified }\end{array}$ \\
\hline China & $\begin{array}{l}\text { Wastewater } \\
\text { discharge to the } \\
\text { environment }\end{array}$ & $\begin{array}{c}\text { Wastewater from hospitals: } \\
\text { Faecal coliforms: } \\
50 \mathrm{MPN} / \mathrm{L} \text { (Class 1); } \\
\text { 1,000 MPN/L (Class 2); } \\
\text { 5,000 MPN/L (Class 3) } \\
\text { units: } \\
\text { Faecal coliforms: } \\
\text { 100 MPN/L (Class 1); } \\
500 \text { MPN/L (Class 2); } \\
\text { 1,000 MPN/L (Class 3) }\end{array}$ \\
\hline
\end{tabular}

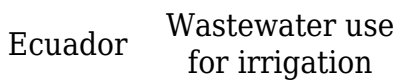

$\begin{array}{ll}\text { El } & \text { Wastewater } \\ \text { Salvador } & \text { discharged to }\end{array}$

Salvador discharged to

Wastewater

Honduras discharged to the environment

Japan

Marine and freshwater sources

Kenya domestic water
Unrestricted irrigation (crops consumed raw, sports fields, and public green spaces): Faecal coliforms: 1,000/100mL Restricted irrigation (crops not consumed raw):

Faecal coliforms: no limit specified

Total coliforms: 10,000 MPN/100mL Faecal coliforms: 2,000 MPN/100mL

Faecal coliforms: $<5,000 / 100 \mathrm{~mL}$ *MPN method preferred but membrane filtration accepted

Category AA Rivers and Lakes:

Total coliforms: $50 \mathrm{MPN} / 100 \mathrm{~mL}$

Category A Rivers, Lakes, and Coastal Bathing Waters:

Total coliforms: 1,000 MPN/100mL

Fishery Class 1 Coastal Waters: $70 \mathrm{MPN} / 100 \mathrm{~mL}$ Category B Rivers:

Total coliforms: 5,000 MPN/100mL

$$
\text { E. coli: }<1 / 100 \mathrm{~mL}
$$

Guideline, Norm, or Standard Reference

Law 1333 - Law of the Environment

MMAyA, 1992

Regulation/GM/No. 0013:

Classifying domestic water courses in order to protect their quality

Brazilian Ministry of Health, 1976
National Standards of the People's Republic of China: Integrated Wastewater Discharge Standard (GB 8978-1996)

Norms for the Study and Design of Potable Water Systems and the Deposition of Wastewater for Populations Greater than 1,000 Inhabitants

Salvadoran Norm: Water, Wastewater Discharged to a Receiving Water Body (NSO 13.49.01:09)

Technical Norm for the Discharge of Wastewater to Receiving Waters and Sanitary Sewers (Agreement No. 058)

Environmental Quality Standards Regarding Water Pollution

IEOS, 1992

Chinese

Environmental Protection Agency, 1996

CONACYT, 2009

ERSAPS, 1996

Japan

Environment Agency, 1986

Environmental Management and Co-ordination (Water Quality) Regulations
Republic of Kenya, 2006 


\begin{tabular}{|c|c|c|c|c|}
\hline Area & Regulatory Use & $\begin{array}{c}\text { Maximum Limit for Faecal Indicator } \\
\text { Bacteria }\end{array}$ & Guideline, Norm, or Standard & Reference \\
\hline Kenya & $\begin{array}{c}\text { Effluent } \\
\text { discharge to the } \\
\text { environment }\end{array}$ & $\begin{array}{l}\text { E. coli: }<1 / 100 \mathrm{~mL} \\
\text { Total coliforms: } 30 / 100 \mathrm{~mL}\end{array}$ & $\begin{array}{c}\text { Environmental Management } \\
\text { and Co-ordination (Water } \\
\text { Quality) Regulations }\end{array}$ & $\begin{array}{l}\text { Republic of } \\
\text { Kenya, } 2006\end{array}$ \\
\hline Kenya & $\begin{array}{l}\text { Wastewater use } \\
\text { in agriculture }\end{array}$ & $\begin{array}{c}\text { Total coliforms: } \\
\text { 1,000 MPN/100mL } \\
\text { (unrestricted irrigation) } \\
200 \text { MPN/100mL } \\
\text { (irrigation of public lawns such as hotel } \\
\text { lawns with which the public may have direct } \\
\text { contact) }\end{array}$ & $\begin{array}{c}\text { Environmental Management } \\
\text { and Co-ordination (Water } \\
\text { Quality) Regulations }\end{array}$ & $\begin{array}{l}\text { Republic of } \\
\text { Kenya, } 2006\end{array}$ \\
\hline Kenya & $\begin{array}{l}\text { Recreational } \\
\text { waters }\end{array}$ & $\begin{array}{l}\text { Faecal coliforms: }<1 / 100 \mathrm{~mL} \\
\text { Total coliforms: } 500 / 100 \mathrm{~mL}\end{array}$ & $\begin{array}{c}\text { Environmental Management } \\
\text { and Co-ordination (Water } \\
\text { Quality) Regulations }\end{array}$ & $\begin{array}{l}\text { Republic of } \\
\text { Kenya, } 2006\end{array}$ \\
\hline Mexico & $\begin{array}{l}\text { Wastewater } \\
\text { discharged to } \\
\text { the environment } \\
\text { and wastewater } \\
\text { reuse in } \\
\text { agriculture }\end{array}$ & $\begin{array}{c}\text { For discharge to water bodies or to land } \\
\text { (irrigation): } \\
\text { Faecal coliforms (monthly average): } \\
<1,000 \mathrm{MPN} / 100 \mathrm{~mL} \\
\text { Faecal coliforms (daily average): } \\
<2,000 \mathrm{MPN} / 100 \mathrm{~mL} \\
\text { For discharge to land only (irrigation): } \\
\text { Helminth eggs: } \\
<1 \text { egg/L (unrestricted irrigation) or } \\
<5 \text { eggs/L (restricted irrigation) }\end{array}$ & $\begin{array}{l}\text { Official Norms to Establish the } \\
\text { Maximum Permissible Limits for } \\
\text { Contaminants in Wastewater } \\
\text { Discharged to National Waters } \\
\text { (NOM-001-ECOL-1996) }\end{array}$ & $\begin{array}{l}\text { CONAGUA, } \\
1997\end{array}$ \\
\hline $\begin{array}{l}\text { Marshall } \\
\text { Islands }\end{array}$ & $\begin{array}{l}\text { Sanitation } \\
\text { discharge to } \\
\text { marine waters }\end{array}$ & Faecal coliforms: 200/100mL & $\begin{array}{l}\text { Marine Water Quality } \\
\text { Regulations }\end{array}$ & $\begin{array}{l}\text { Republic of } \\
\text { Marshall } \\
\text { Islands } \\
\text { Environmental } \\
\text { Protection } \\
\text { Authority, } \\
1992\end{array}$ \\
\hline $\begin{array}{l}\text { Palau, } \\
\text { Marshall } \\
\text { Islands }\end{array}$ & $\begin{array}{l}\text { Marine and } \\
\text { freshwater } \\
\text { sources }\end{array}$ & $\begin{array}{c}\text { Class AA Waters and Class } 1 \text { Groundwater: } \\
\text { Total coliform (median of } 10 \text { samples): } \\
\text { 70/100mL } \\
\text { Total coliform: } 230 / 100 \mathrm{~mL} \\
\text { (any one sample) } \\
\text { Faecal coliform: } \\
\text { 200/100mL } \\
\text { Class A/B Waters and Class } 2 \text { Groundwater: } \\
\text { (geometric mean of } 10 \text { samples) } \\
\text { Faecal coliform: } 400 / 100 \mathrm{~mL} \\
\text { (any one sample) } \\
\text { Class AA/A Waters (Palau): } \\
\text { Enterococci: 33/100mL } \\
\text { (geometric mean of } 5 \text { samples) } \\
\text { Enterococci: } 60 / 100 \mathrm{~mL} \\
\text { (any one sample) } \\
\text { Class AA and Shellfish Waters (Marshall } \\
\text { Islands): } \\
\text { Enterococci: } \\
7 / 100 \mathrm{~mL} \\
\text { (arithmetic mean of } 5 \text { samples) } \\
\text { Class A Waters (Marshall Islands): } \\
\text { Enterococci: } \\
35 / 100 \mathrm{~mL} \\
\text { (arithmetic mean of } 5 \text { samples) }\end{array}$ & $\begin{array}{l}\text { Chapter 2401-11. Marine and } \\
\text { Fresh Water Quality } \\
\text { Regulations } \\
\text { Marine Water Quality } \\
\text { Regulations (Marshall Islands) }\end{array}$ & $\begin{array}{l}\text { Republic of } \\
\text { Marshall } \\
\text { Islands } \\
\text { Environmental } \\
\text { Protection } \\
\text { Authority, } \\
\text { 1992; } \\
\text { Repuclic of } \\
\text { Palau, } 1996\end{array}$ \\
\hline $\begin{array}{l}\text { Papua } \\
\text { New } \\
\text { Guinea }\end{array}$ & $\begin{array}{l}\text { Marine and } \\
\text { freshwater } \\
\text { sources }\end{array}$ & $\begin{array}{c}\text { Freshwater: } \\
\text { Faecal coliforms: } \\
200 / 100 \mathrm{~mL} \\
\text { (median of } 5 \text { samples) } \\
\text { Seawater: } \\
\text { No regulations for faecal indicator bacteria }\end{array}$ & $\begin{array}{l}\text { Environment (Water Quality } \\
\text { Criteria) Regulation }\end{array}$ & $\begin{array}{l}\text { Papua New } \\
\text { Guinea } \\
\text { Consolidated } \\
\text { Legislation, } \\
2006\end{array}$ \\
\hline
\end{tabular}




\begin{tabular}{|c|c|c|c|c|}
\hline Area & Regulatory Use & $\begin{array}{c}\text { Maximum Limit for Faecal Indicator } \\
\text { Bacteria }\end{array}$ & Guideline, Norm, or Standard & Reference \\
\hline Sri Lanka & $\begin{array}{c}\text { Treated } \\
\text { Wastewater }\end{array}$ & $\begin{array}{l}\text { Discharge to Inland Surface Waters: } \\
\text { Faecal coliforms: } 40 \text { MPN/100mL (max) } \\
\text { Discharge on Land for Irrigation: } \\
\text { Faecal coliforms: } 40 \text { MPN/100mL (max) } \\
\text { Discharge to Marine Coastal Areas: } \\
\text { Faecal coliforms: } 60 \text { MPN/100mL (max) }\end{array}$ & $\begin{array}{l}\text { National Environmental Act, No. } \\
47 \text { of } 1980\end{array}$ & $\begin{array}{l}\text { Sri Lankan } \\
\text { Ministry of } \\
\text { Environment } \\
\text { and Natural } \\
\text { Resources, } \\
2008\end{array}$ \\
\hline Turkey & $\begin{array}{c}\text { Treated } \\
\text { Wastewater }\end{array}$ & $\begin{array}{c}\text { Discharge to Class I Waters: } \\
\text { Total coliforms: } 100 \mathrm{MPN} / 100 \mathrm{~mL} \\
\text { Faecal coliforms: } 10 \mathrm{MPN} / 100 \mathrm{~mL} \\
\text { Discharge to Class II Waters: } \\
\text { Total coliforms: 2,000 MPN/100mL } \\
\text { Faecal coliforms: } 200 \mathrm{MPN} / 100 \mathrm{~mL} \\
\text { Discharge to Class III Waters: } \\
\text { Total coliforms: 10,000 MPN/100mL } \\
\text { Faecal coliforms: 2,000 MPN/100mL }\end{array}$ & $\begin{array}{l}\text { Regulation for Water Pollution } \\
\text { Control. Environment Law No. } \\
\qquad 2872\end{array}$ & $\begin{array}{l}\text { Government } \\
\text { of Turkey, } \\
1988\end{array}$ \\
\hline UK & $\begin{array}{l}\text { Inland Bathing } \\
\text { Waters }\end{array}$ & $\begin{array}{c}\text { Classification "Excellent” (95th percentile of } \\
\log _{10} \text { densities): } \\
\text { Enterococci: } 200 \mathrm{CFU} / 100 \mathrm{~mL} \\
\text { E. coli: } 500 \mathrm{CFU} / 100 \mathrm{~mL} \\
\text { Classification “Good” (95th percentile of } \\
\left.\log _{10} \text { densities }\right):^{-} \\
\text {Enterococci: } 400 \mathrm{CFU} / 100 \mathrm{~mL} \\
\text { E. coli: } 1,000 \mathrm{CFU} / 100 \mathrm{~mL} \\
\text { Classification "Sufficient” (90th percentile of } \\
\log _{10} \text { densities): } \\
\text { Enterococci: } 330 \mathrm{CFU} / 100 \mathrm{~mL} \\
\text { E. coli: } 900 \mathrm{CFU} / 100 \mathrm{~mL}\end{array}$ & $\begin{array}{l}\text { The (Quality of) Bathing } \\
\text { Water(s) Regulations }\end{array}$ & $\begin{array}{l}\text { United } \\
\text { Kingdom } \\
\text { (Scotland), } \\
\text { 2008; United } \\
\text { Kingdom } \\
\text { (England and } \\
\text { Wales), } 2013\end{array}$ \\
\hline UK & $\begin{array}{l}\text { Coastal Bathing } \\
\text { Waters }\end{array}$ & $\begin{array}{c}\text { Classification "Excellent" } \\
\text { (95th percentile of } \log _{10} \text { densities): } \\
\text { Enterococci: } 100 \mathrm{CFU} / 100 \mathrm{~mL} \\
\text { E. coli: } 250 \mathrm{CFU} / 100 \mathrm{~mL} \\
\text { Classification "Good" } \\
\text { (95th percentile of } \log _{10} \text { densities): } \\
\text { Enterococci: } 200 \mathrm{CFU} / 100 \mathrm{~mL} \\
\text { E. coli: } 1,000 \mathrm{CFU} / 100 \mathrm{~mL} \text { (inland); } 500 \\
\text { CFU/100mL } \\
\text { Classification "Sufficient" } \\
\text { (90th percentile of } \log _{10} \text { densities): } \\
\text { Enterococci: } 185 \mathrm{CFU} / 100 \mathrm{~mL} \\
\text { E. coli: } 500 \mathrm{CFU} / 100 \mathrm{~mL}\end{array}$ & $\begin{array}{l}\text { The (Quality of) Bathing } \\
\text { Water(s) Regulations }\end{array}$ & $\begin{array}{l}\text { United } \\
\text { Kingdom } \\
\text { (Scotland), } \\
\text { 2008; United } \\
\text { Kingdom } \\
\text { (England and } \\
\text { Wales), } 2013\end{array}$ \\
\hline USA & $\begin{array}{l}\text { Surface Water } \\
\text { (or groundwater } \\
\text { under the direct } \\
\text { influence of } \\
\text { surface water) } \\
\text { for public water } \\
\text { supply systems }\end{array}$ & $\begin{array}{c}\text { Cryptosporidium } \\
\text { (arithmetic mean of samples from } 12 \\
\text { months): } \\
0.075 \text { oocysts/L } / \mathrm{L}^{\mathrm{a}} \\
1 \text { oocysts } / \mathrm{L}^{\mathrm{b}} \\
3 \text { oocysts } / \mathrm{L}^{\mathrm{c}} \\
>3 \text { oocysts } / \mathrm{L}^{\mathrm{d}}\end{array}$ & $\begin{array}{c}\text { National Primary Drinking } \\
\text { Water Regulations: Long-Term } 2 \\
\text { Enhanced Surface Water } \\
\text { Treatment Rule (LT2ESWTR) }\end{array}$ & USEPA, 2006 \\
\hline
\end{tabular}




\begin{tabular}{|c|c|c|c|c|}
\hline Area & Regulatory Use & $\begin{array}{c}\text { Maximum Limit for Faecal Indicator } \\
\text { Bacteria }\end{array}$ & Guideline, Norm, or Standard & Reference \\
\hline USA & $\begin{array}{l}\text { Recreational } \\
\text { Water }\end{array}$ & $\begin{array}{c}\text { Recommendation } 1 \\
\text { (for an estimated illness rate of 36/1,000): } \\
\text { Enterococci (marine and freshwater): } \\
35 \text { CFU/100mL (geometric mean); } \\
130 \mathrm{CFU} / 100 \mathrm{~mL} \\
\text { (10\% statistical threshold value) } \\
\text { E. coli (freshwater only): } \\
126 \mathrm{CFU} / 100 \mathrm{~mL} \text { (geometric mean); } \\
410 \mathrm{CFU} / 100 \mathrm{~mL} \\
\text { (10\% statistical threshold value) } \\
\text { Recommendation } 2 \\
\text { (for an estimated illness rate of 32/1,000): } \\
\text { Enterococci (marine and freshwater): } \\
30 \mathrm{CFU} / 100 \mathrm{~mL} \text { (geometric mean); } \\
110 \mathrm{CFU} / 100 \mathrm{~mL} \\
\text { (10\% statistical threshold value) } \\
E . \text { coli (freshwater only): } \\
100 \mathrm{CFU} / 100 \mathrm{~mL} \text { (geometric mean); } \\
320 \mathrm{CFU} / 100 \mathrm{~mL} \\
\text { (10\% statistical threshold value) }\end{array}$ & $\begin{array}{l}\text { Recreational Water Quality } \\
\text { Criteria (EPA 820-F-12-058) }\end{array}$ & USEPA, 2012 \\
\hline \multicolumn{5}{|c|}{${ }^{a}$ Classification used to guide the treatment needed for drinking water (type of filtration can be used) } \\
\hline \multicolumn{5}{|c|}{$\begin{array}{l}\text { Note: if the system uses filtration AND serves }<10,000 \text { people AND the } E \text {. coli concentration } \\
\text { is }<10 / 100 \mathrm{~mL} \text { (in lake/reservoir sources) or }<50 / 100 \mathrm{~mL} \text { (in flowing stream sources), }\end{array}$} \\
\hline \multicolumn{5}{|c|}{ Cryptosporidium monitoring is not required and any type of filtration can be used; } \\
\hline $\begin{array}{l}{ }^{\mathrm{b}} \text { requ } \\
{ }^{\mathrm{c}} \text { requ } \\
{ }^{\mathrm{d}} \text { requires }\end{array}$ & $\begin{array}{l}\text { es filtration for dri } \\
\text { es filtration for dri } \\
\text { iltration for drinkil }\end{array}$ & $\begin{array}{l}\text { nking water and } 4.0 \log _{10} \text { removal of Cryptos } \\
\text { nking water and } 5.0 \log _{10} \text { removal of Cryptos } \\
\text { g water and } 5.5 \log _{10} \text { removal of Cryptospor }\end{array}$ & $\begin{array}{l}\text { poridium; } \\
\text { poridium; } \\
\text { idium; }\end{array}$ & \\
\hline
\end{tabular}

Table 3. Summary of general faecal indicator bacteria norms, regulations, and standards in drinking water

\begin{tabular}{|c|c|c|c|c|}
\hline Area & Regulatory Use & $\begin{array}{c}\text { Maximum Limit for Faecal } \\
\text { Indicator Bacteria }\end{array}$ & Guideline, Norm, or Standard & Reference \\
\hline Global & Drinking water & $\begin{array}{c}\text { E. coli (or thermotolerant } \\
\text { coliforms): } \\
<1 / 100 \mathrm{~mL} \\
\text { The use of a health-based } \\
\text { approach derived from } \\
\text { quantitative microbial risk } \\
\text { assessment is also } \\
\text { recommended in the } 4 \text { th edition } \\
\text { of these guidelines }\end{array}$ & $\begin{array}{c}\text { World Health Organization } \\
\text { Drinking Water Quality } \\
\text { Guidelines }\end{array}$ & WHO, 2011 \\
\hline Argentina & Drinking water & $\begin{array}{c}\text { E. coli: }<1 / 100 \mathrm{~mL} \\
\text { Total coliforms: } 3 / 100 \mathrm{~mL}\end{array}$ & $\begin{array}{c}\text { Food Code (Decree No. 2126/71, } \\
\text { Regulation for Law 18.284, } \\
\text { Chapter XII) }\end{array}$ & $\begin{array}{c}\text { Administracion } \\
\text { Nacional de } \\
\text { Medicamentos, } 2012\end{array}$ \\
\hline Belize & Drinking water & $\begin{array}{c}\text { Faecal coliforms: }<1 / 100 \mathrm{~mL} \\
\text { Faecal streptococci: }<1 / 100 \mathrm{~mL} \\
\text { Heterotrophic plate count at } \\
22^{\circ} \mathrm{C}: 100 \mathrm{CFU} / \mathrm{mL} \\
\text { Heterotrophic plate count at } \\
37^{\circ} \mathrm{C}: 20 \mathrm{CFU} / \mathrm{mL}\end{array}$ & $\begin{array}{l}\text { Chapter } 211 \text {. Belize agricultural } \\
\text { health authority (food processing } \\
\text { plants) (potable water) } \\
\text { (minimum standards) regulations }\end{array}$ & $\begin{array}{l}\text { Belize Agricultural } \\
\text { Health Authority, } \\
2001\end{array}$ \\
\hline
\end{tabular}


Bolivia Drinking water

Brazil

Chile

Colombia

Drinking water

Costa Rica

Drinking water
E. coli: $<1 \mathrm{CFU} / 100 \mathrm{~mL}$ or $<5$ $\mathrm{MPN} / 100 \mathrm{~mL}$

Total coliforms: $<1 \mathrm{CFU} / 100 \mathrm{~mL}$ or $<5 \mathrm{MPN} / 100 \mathrm{~mL}$

Entrance of Piped Distribution Network:

Total coliforms: $<1 / 100 \mathrm{~mL}$

Faecal coliforms: $<1 / 100 \mathrm{~mL}$

Other Locations in Piped

Distribution Network:

Total coliforms: Absence in

$100 \mathrm{~mL}$ in $95 \%$ of samples and

$<3 / 100 \mathrm{~mL}$ in $5 \%$ of samples (for

systems with treatment); $98 \%$ absence and $2 \%$ with $<3 / 100 \mathrm{~mL}$

(systems without treatment)

Faecal coliforms: $<1 / 100 \mathrm{~mL}$

Communal wells and springs (non-piped systems):

Total coliforms: Absence in

$100 \mathrm{~mL}$ in $95 \%$ of samples and

$<10 / 100 \mathrm{~mL}$ in $5 \%$ of samples

Faecal coliforms: $<1 / 100 \mathrm{~mL}$

Potable Water: Faecal coliforms: $\mathrm{Nil} / 100 \mathrm{~mL}$

Water in Piped Distribution Network:

Total coliforms: Present in 10\% of samples when 10 or more

samples analyzed per month or present in only one sample if $<10$ samples analyzed per month; concentrations

$>5 / 100 \mathrm{~mL}$ only allowable in $5 \%$

of samples if 20 or more samples analyzed per month or in no more than one sample if $<20$ samples analyzed per month

$$
\text { E. coli: }<1 / 100 \mathrm{~mL}
$$

Total coliforms: $<1$ CFU/100mL or $<2 \mathrm{MPN} / 100 \mathrm{~mL}$

Faecal coliforms: $<1 / 100 \mathrm{~mL}$ (for water entering the

distribution network, water at all points within the distribution network, and for all types of drinking water and ice)
Technical Norms for Potable Water Quality. Decree 475-1998.

Bolivian Norm NB 512 - Quality

of potable water for human consumption (Norma Bolivia NB 512 - Calidad de agua potable para el consumo humano)

IBNORCA, 2016

Portaria No. 36/MS/GM: Norms and Standards for Potable Water Brazilian Ministry of Destined for Human Consumption

Health, 1990

Official Chilean Norm 409/1: Drinking Water

INN Chile, 1984

Colombian Ministry of Health, 1998

Decree No. 25991-S: Regulations Costa Rican Ministry of Health, 1997 
Ecuador

El

Salvador

Estonia

Drinking water

Honduras Drinking water

Drinking water

Drinking water

Drinking water
Water Supply Source:

Total coliforms:

$<50 / 100 \mathrm{~mL}$ (requires

disinfection only)

50 to $5,000 / 100 \mathrm{~mL}$ (requires

conventional treatment)

5,000 to $50,000 / 100 \mathrm{~mL}$ or if

$>40 \%$ of coliforms are faecal

coliforms (requires "more active" treatment)

Norms for the Study and Design of Potable Water Systems and

$>50,000 / 100 \mathrm{~mL}$ (not acceptable the Deposition of Wastewater for for drinking water) Treated Water: Populations Greater than 1000 Inhabitants

Total coliforms: $1 \mathrm{CFU} / 100 \mathrm{~mL}$

(monthly arith. mean). Maximum

for a single sample is $4 \mathrm{CFU} /$

$100 \mathrm{~mL}$ (if <20 samples analyzed per month) or 4

CFU/100mL (in $5 \%$ of samples per month if $>20$ samples analyzed)

Total coliforms: $<1 \mathrm{CFU} / 100 \mathrm{~mL}$ or $<1.1 \mathrm{MPN} / 100 \mathrm{~mL}$ Faecal coliforms: $<1$ CFU/100mL or $<1.1 \mathrm{MPN} / 100 \mathrm{~mL}$

E. coli: $<1 \mathrm{CFU} / 100 \mathrm{~mL}$ or $<1.1 \mathrm{MPN} / 100 \mathrm{~mL}$

Heterotrophic plate count: $<100$ $\mathrm{CFU} / \mathrm{mL}$

Distributed public water supply, containers and tanks:

E. coli: $<1 \mathrm{CFU} / 100 \mathrm{~mL}$

Enterococci: $<1 \mathrm{CFU} / 100 \mathrm{~mL}$

Bottled into bottles or jerrycans: E. coli: $<1 \mathrm{CFU} / 100 \mathrm{~mL}$

Enterococci: $<1 \mathrm{CFU} / 100 \mathrm{~mL}$

Pseudomonas aeruginosa: $<1$ $\mathrm{CFU} / 100 \mathrm{~mL}$

Heterotrophic plate count at $22^{\circ} \mathrm{C}: 100 \mathrm{CFU} / \mathrm{mL}$

Heterotrophic plate count at $37^{\circ} \mathrm{C}: 20 \mathrm{CFU} / \mathrm{mL}$

Recommended Values:

Total coliforms: $<1 / 100 \mathrm{~mL}$

Faecal coliforms: $<1 / 100 \mathrm{~mL}$

E. coli: not required, but

recommended as the "most precise faecal bacterial

indicator" to be used in place of or in addition to faecal coliforms Maximum Values Permitted: Total coliforms: 3/100mL (for untreated water entering the distribution network and water within the distribution network; this value is permitted occasionally but not in consecutive samples);

10/100mL (non-piped water supply; not permitted in repeated samples)

Faecal coliforms: $<1 / 100 \mathrm{~mL}$
Salvadoran Norm: Water, Potable Water (NSO 13.07.01:08)
Quality and control requirements and analysis methods for drinking water
Technical Norm for the Quality of Potable Water (Agreement No. 084): Annex 1

IEOS, 1992

United Kingdom

(Scotland), 2008
Honduran Ministry of Health, 1995 
Israel

Palau

Singapore

Tanzania

UK

UK

Drinking Water (service reservoirs, treatment works)

$\mathrm{UK}$

Drinking water

Drinking water

Public water supply systems

Piped water supplies (nonchlorinated)

Drinking Water (at the tap)

\section{Drinking Water} (water supply
Total coliforms: $3 / 100 \mathrm{~mL}$

Faecal coliforms: $<1 / 100 \mathrm{~mL}$ point)
Faecal streptococcus: $<1 / 100 \mathrm{~mL}$ Heterotrophic plate count: $1,000 / \mathrm{mL}$

E. coli: $<1 / 100 \mathrm{~mL}$

Total coliforms: $<1 / 100 \mathrm{~mL}$

For systems serving $<50,000$ inhabitants:

Total coliforms: None detected

in $95 \%$ of samples collected over a period of 12 months

Total coliform (presence/absence):

No more than 1 positive sample

(100 mL) per month (if $<40$ samples per month), or no more than $5.0 \%$ positive samples per month (if $>40$ samples per month)

Faecal coliform or E. coli: $<1 / 100 \mathrm{~mL}$

E. coli (or thermotolerant coliforms): $<1 / 100 \mathrm{~mL}$ )

Excellent Classification:

Total coliforms: $<1 / 100 \mathrm{~mL}$

E. coli (faecal coliforms): $<1 / 100 \mathrm{~mL}$

Satisfactory Classification:

Total coliforms: 1 to 3/100mL

E. coli (faecal coliforms): $<1 / 100 \mathrm{~mL}$

Suspicious Classification:

Total coliforms: 4 to 10/100mL

E. coli (faecal coliforms): $<1 / 100 \mathrm{~mL}$

Unsatisfactory Classification:

E. coli (faecal coliforms): $>0 / 100 \mathrm{~mL}$

At the Consumer's Tap (from Directive 98/83/EC):

Enterococci: $<1 / 100 \mathrm{~mL}$ E. coli: $<1 / 100 \mathrm{~mL}$

Service Reservoirs and Treatment Works:

Coliform bacteria: $<1 / 100 \mathrm{~mL}$ (95\% of samples)

E. coli: $<1 / 100 \mathrm{~mL}$

Water Supply Point: Coliform bacteria: $<1 / 100 \mathrm{~mL}$ Clostridium perfringens: $<1 / 100 \mathrm{~mL}$
Total coliforms: $>10 / 100 \mathrm{~mL}$
Regulations Concerning the Sanitary Quality of Drinking Water

Israeli Ministry of Health, 1991

Official Norms for the Quality of Water in Mexico (NOM-127SSA1-1994)

COFREPRIS, 1994

Chapter 2401-51. Public Water Supply System Regulations

Republic of Palau, 1996

Environmental Public Health Act (Chapter 95): Environmental Public Health (Quality of Piped Drinking Water) Regulations

Singapore National Environment Agency, 2008

Regulations for the

Environmental Management Act Tanzania Minister of (Water Quality Standards, Cap. 191)

State, 2005

Water Supply (Water Quality) Regulations; implementation of Council Directive 98/83/EC

Water Supply (Water Quality) Regulations; implementation of Council Directive 98/83/EC

Water Supply (Water Quality) Regulations; implementation of Council Directive 98/83/EC
United Kingdom

(Scotland), 2001;

United Kingdom

(Northern Ireland), 2007; United

Kingdom (England and Wales), 2010

United Kingdom

(Scotland), 2001;

United Kingdom

(Northern Ireland), 2007; United

Kingdom (England and Wales), 2010

United Kingdom

(Scotland), 2001;

United Kingdom

(Northern Ireland), 2007; United

Kingdom (England and Wales), 2010 
Total coliforms: $<1 / 100 \mathrm{~mL}$ (no

more than $5.0 \%$ positive of $\geq 40$

samples/month or no more than

1 sample positive of $<40$ samples/month)

E. coli: $<1 / 100 \mathrm{~mL}$

(the situations below also

represent non-compliance)

Any positive E. coli repeat sample

Repeat sample positive for $E$. coli following positive total coliform routine sample or vice versa

Failure to take repeat samples

following an $E$. coli positive routine sample or the failure to test for E. coli following a positive repeat sample for total coliform
National Primary Drinking Water

Regulations: Revisions to the Total Coliform Rule
USEPA, 2006

\subsubsection{Coliforms}

The term coliform represents a large group of bacterial species that are not rigidly defined by taxonomy, but rather by their ability to ferment lactose with gas and acid production, or their ability to use particular enzymes to break down carbohydrates. Coliforms are facultative anaerobic, Gram-negative, rod-shaped, non-spore forming, oxidase-negative bacteria that are resistant to bile salts and belong to the family Enterobacteriaceae. Dominant genera include Citrobacter, Escherichia, Enterobacter, and Klebsiella. Coliforms are shed in the faeces of humans and other animals at daily rates exceeding one billion bacteria per individual. They are most common in warm-blooded animals, but have also been detected in the faeces of some cold-blooded animals including alligators (Johnston et al., 2010), turtles (Harwood et al., 1999), and fish (Sousa et al., 2011). Furthermore, some coliform species and strains (particularly Klebsiella spp.) can originate from riparian soils, beach sands, as well as marine or freshwater sediments, and can proliferate in the environment under certain conditions (Sadowsky and Whitman, 2011). For over a century, coliform enumeration was accomplished exclusively by cultivation methods. Because the selectivity of these methods is influenced by a number of factors such as ability to utilize a defined growth substrate (carbon and energy source), response to inhibitors of non-coliforms, incubation temperature, and detection of by-products (e.g. acids, gas, enzymes) that produce a colorimetric reaction, these methods are subject to both false-positive and falsenegative errors (see Applications for details).

Thermotolerant coliforms (also known as faecal coliforms) are a subset of the total coliform group capable of growth at elevated temperatures $\left(\sim 44.5^{\circ} \mathrm{C}\right)$. E. coli is generally distinguished from other thermotolerant coliforms by production of the enzyme beta-glucuronidase, the subject of the MUG test. Standardized methods are used in practice and in regulatory settings to quantify total coliforms, thermotolerant coliforms, and E. coli in water samples. In general, total coliforms are most commonly used as indicators for groundwater, drinking water supply, and potable water impairment, while thermotolerant coliforms and E. coli are more commonly used as indicators for shellfish and recreational water quality testing. The drawback of growth under permissive environmental conditions is shared by thermotolerant coliforms and E. coli (Solo-Gabriele et al., 2000; Vanden Heuval et al., 2010).

\subsubsection{Total coliforms}

Because of their ubiquitous occurrence in the environment, total coliforms can no longer be considered indicators of faecal pollution. Total coliforms have been historically defined by phenotype as bacteria that ferment lactose to produce gas and acid within $48 \mathrm{~h}$ at $35^{\circ} \mathrm{C}$ (APHA, 2012). A more recently-developed methodology defines them as bacteria that possess the enzyme $\beta$-galactosidase, which cleaves lactose or the synthetic chromogenic substrate used for the assay (Sadowsky and Whitman, 2011). It is important to note that some coliforms are not capable of producing gas and acid from lactose fermentation; also, some species of bacteria that do not ferment lactose at $35^{\circ} \mathrm{C}$ possess the gene for $\beta$ galactosidase, and coliform bacteria that possess the gene may not always express it (Sadowsky and Whitman, 2011; Pisciotta et al., 2002).

\subsubsection{Thermotolerant coliforms}

Thermotolerant coliforms are operationally defined as the subset of total coliforms that are capable of growth within $24 \mathrm{~h}$ at $44.5^{\circ} \mathrm{C}$ with either gas and acid production or activity by the $\beta$-galactosidase enzyme (Sadowsky and Whitman, 2011). The group consists primarily of E. coli and some Klebsiella spp., with the former usually accounting for 
the majority of thermotolerant coliforms in faecal sources. However, members of related bacterial genera such as Enterobacter and Citrobacter may come from faecal or nonfaecal sources, and are also capable of growth at $44.5^{\circ} \mathrm{C}$ (Figueras et al., 1994). Many countries have adopted the use of coliforms or E. coli for regulating surface water quality (Table 2). Thermotolerant coliforms are widely distributed in human and other animal faeces.

\subsubsection{Escherichia coli}

E. coli is a thermotolerant member of the coliform group (also known as faecal coliform). It is usually motile via flagella. E. coli are easily cultivated in the laboratory, and phenotypic identification relies on lactose fermentation, while generating acid and gas byproducts, and the reduction of nitrate to nitrite. Most E. coli strains produce indole from tryptophan and do not use citrate as a sole carbon source (Sadowsky and Whitman, 2011). Most strains also produce the enzyme $\beta$-glucuronidase (WHO, 2011), an important differential characteristic of many types of culture media, although up to $10 \%$ of environmental strains are $\beta$-glucuronidase negative. $E$. coli is ubiquitous in the normal intestinal community and faeces of most animals, so it cannot be used to distinguish pollution by human waste or domestic wastewater from pollution originating from other animal sources. While most strains of E. coli are not pathogenic, some strains can cause potentially fatal illnesses, many of which are foodborne. For example, enterotoxigenic and enteropathogenic E. coli are major causative agents of diarrhea, particularly in developing countries. Enteroinvasive E. coli is a causative agent of dysentery, and enterohemorrhagic E. coli causes hemorrhagic colitis and hemolytic uremic syndrome (Levine, 1987). For more about disease-causing strains of E. coli, refer to Part Three, Section II: Bacteria.

\subsubsection{Enterococci and faecal Streptococci}

Enterococci and faecal streptococci are phenotypically defined as fermentative, Gram-positive, catalase-negative cocci that form characteristic colonies on certain selectivedifferential media containing sodium azide, which is inhibitory to Gram-negative bacteria. Their carbon and energy metabolism is predominantly fermentative, therefore they do not require oxygen, but they are not harmed by it. The faecal streptococci designation and the genus Streptococcus originally included the phenotypicallydefined enterococci group; however, when differences at the DNA level were recognized in the 1980s, a new genus, termed Enterococcus, was designated (Murray, 1990). Most members of the genus Enterococcus can grow under relatively non-permissive conditions (e.g. at $10^{\circ} \mathrm{C}$ and $45^{\circ} \mathrm{C}$, and in $6.5 \% \mathrm{NaCl}$ ), and therefore, can be differentiated phenotypically from faecal streptococci belonging to the genus Streptococcus (e.g. Streptococcus bovis). Note that the term enterococci is defined phenotypically, while the genus Enterococcus is defined phylogenetically (DNAbased). In practice, the terms are used interchangeably, sometimes leading to confusion.

It is not possible to differentiate among sources of faecal contamination based on the speciation of faecal streptococci or enterococci (APHA, 2012). Faecal streptococci are less numerous than coliforms in human faeces, which in theory could make them a less sensitive indicator of faecal contamination than coliforms, however in practice this is generally not an issue. The ratio of faecal coliforms to faecal streptococci (FC/FS ratio) was previously proposed to differentiate sources of faecal pollution; however, it was later shown that this approach was not valid. Differences in inactivation rates of these FIB groups, the potential for growth in the environment, and variability between host groups were major drawbacks for source determination (Howell et al., 1996). As a result, the use of the FC/FS ratio is no longer an acceptable method and was removed from the American Public Health Association Standard Methods for the Examination of Water and Wastewater as of 1998 (Meays et al., 2004).

\subsubsection{Anaerobic faecal bacteria}

Several groups of anaerobic faecal bacteria, including Bifidobacteria, Clostridia, and Bacteroidales, are also used as FIB, in practice and research, though to a lesser extent than coliforms and enterococci. Limited use in regulatory settings is often hindered due to the requirement for anaerobic incubation (Table 2). Bifidobacteria are Grampositive, rod-shaped, non-spore-forming, catalase-negative, obligate anaerobes that belong to the genus Bifidobacterium. They have been found in the faeces of humans, pigs, cattle, sheep, and dogs, and also in the human oral cavity and reproductive system (Wilson, 2005). Bifidobacteria can ferment different types of sugars and hydrolyze a variety of polysaccharides, proteins, and peptides, and they produce acid from glucose (Wilson, 2005).

\subsubsection{Bacteroidales}

Bacteroidales is an order of obligately anaerobic bacteria. Some species are readily cultured from human and other animal digestive tracts and faeces (Coyne and Comstock, 2008); but many phylotypes are known only by their DNA sequences (McLellan and Eren, 2014). Some populations within this order are highly host-associated, and occupy strict niches within the digestive tract of a select animal groups (Coyne and Comstock, 2008). Bacteroides, a genus within the order Bacteroidales, includes bacterial species that are pleomorphic (variable shape and size), anaerobic, non-spore-forming, generally non-motile, and rod-shaped (Wilson, 2005). They are one of the most abundant species in the human large intestine, with approximately 10 billion cells in each gram of human faeces (Madigan and Martinko, 2006). Most Bacteroides spp. are commensal organisms, but some can be opportunistic pathogens (e.g Bacteroides fragilis) (Wexler, 2012). The genetic marker GenBac for the 16S rRNA gene of the Bacteroidetes (Dick and Field, 2004; Shanks et al., 2012) is used in practice as a general faecal indicator, and due to close host-associations of some Bacteroides species, other markers are used in MST applications to characterize faecal contamination from humans or other animals (see following section on host-associated bacteria). 


\subsubsection{Clostridium}

Clostridium spp. are obligately anaerobic, endosporeforming, Gram-positive, rod-shaped bacteria that are generally motile. The most common species isolated from the human gastrointestinal system include $C$. perfringens, $C$. ramosum, $C$. innocuum, $C$. paraputrificum, $C$. sporogenes, $C$. tertium, $C$. bifermentans, and $C$. butyricum. Sulfite-reducing clostridia are non-motile, and are normally present in faeces, although typically at lower concentrations compared to E. coli. These clostridia can ferment lactose and produce gas. Their spores can tolerate temperatures of $75^{\circ} \mathrm{C}$ for $15 \mathrm{~min}$, allowing them to typically survive longer than coliforms in water, and they are more resistant to disinfection mechanisms than vegetative cells. Important factors to consider with the use of Clostridium spp. as a faecal indicator, are that their spores are extremely persistent in the environment, and that some species are excreted by $<35 \%$ of human hosts (Ashbolt et al., 2001). Nevertheless, within the past few decades, researchers report that $C$. perfringens can be a useful conservative tracer of faecal pollution from humans and carnivorous animals, because it rarely appears in the excreta of herbivorous animals (Hill et al., 1996; Vierheilig et al., 2013).

\subsection{Description of MST Methods}

The basic premise underlying MST is that some faecal microorganisms are strongly associated with the gastrointestinal tract of a particular host species (e.g. human) or a larger taxonomic group of closely related species (e.g. ruminant animals such as cattle, goats, sheep, and deer). To date, there is a wide range of technologies reported to identify these host-associated microorganisms ranging from canine scent detection to next generation sequencing (Boehm et al., 2013). The most widely used technologies utilize the polymerase chain reaction (PCR) (Stewart et al., 2013). By combining the concept of hostassociated bacteria with PCR, a central MST hypothesis emerges suggesting that host-associated genetic markers measured by PCR can act as metrics of faecal contamination from a particular animal group. The following section describes well-established, PCR-based methods targeting genetic markers that are closely associated with human, ruminant, porcine, and avian faecal pollution sources (Table 4).

Table 4. Summary of selected host-associated bacterial indicator (MST) methods

\begin{tabular}{|c|c|c|c|c|c|}
\hline Animal Group & Target Organism & Common Target Name & Specific Gene Target & Chemistry & Reference \\
\hline Human & Bacteroidales & HF183 & $\begin{array}{c}\text { 16S rRNA } \\
\text { Bacteroides-Prevotella } \\
\text { group }\end{array}$ & End-point & $\begin{array}{l}\text { Bernhard and } \\
\text { Field, } 2000\end{array}$ \\
\hline Human & Bacteroidales & HF183 & $\begin{array}{c}\text { 16S rRNA } \\
\text { Bacteroides-Prevotella } \\
\text { group }\end{array}$ & SYBR & $\begin{array}{l}\text { Seurinck et al., } \\
2005\end{array}$ \\
\hline Human & Bacteroidales & HF183 & $\begin{array}{c}\text { 16S rRNA } \\
\text { Bacteroides-Prevotella } \\
\text { group }\end{array}$ & TaqMan & $\begin{array}{l}\text { Haugland et } \\
\text { al., } 2010\end{array}$ \\
\hline Human & Bacteroidales & $\mathrm{BacH}$ & $\begin{array}{c}\text { 16S rRNA } \\
\text { Bacteroidetes }\end{array}$ & TaqMan & $\begin{array}{c}\text { Reischer et al., } \\
2007\end{array}$ \\
\hline Human & Bacteroidales & Bac-Hum UCD & $\begin{array}{c}\text { 16S rRNA } \\
\text { Bacteroidales }\end{array}$ & Taqman & $\begin{array}{l}\text { Kildare et al., } \\
2007\end{array}$ \\
\hline Human & Bacteroidales & HumM2 & Hypothetical protein & TaqMan & $\begin{array}{l}\text { Shanks et al., } \\
2009\end{array}$ \\
\hline Human & Bacteroidales & B. thetaiotamicron & $\begin{array}{l}\text { 1,6-alpha mannanase } \\
\text { of } B \text {. thetaiotamicron }\end{array}$ & TaqMan & $\begin{array}{l}\text { Yampara-Iquise } \\
\text { et al., } 2008\end{array}$ \\
\hline Human & Methanogens & nifH & $\begin{array}{c}\text { nifH (nitrogenase) } \\
\text { gene of } \\
\text { Methanobrevibacter } \\
\text { smithii }\end{array}$ & End-point & $\begin{array}{l}\text { Ufnar et al., } \\
2006\end{array}$ \\
\hline Human & Methanogens & nifH & $\begin{array}{c}\text { nifH (nitrogenase) } \\
\text { gene of } \\
\text { Methanobrevibacter } \\
\text { smithii }\end{array}$ & TaqMan & $\begin{array}{c}\text { Johnston et al., } \\
2010\end{array}$ \\
\hline Human & Bifidobacteria & Bifidobacteria & $\begin{array}{l}16 \mathrm{~S} \text { rRNA } B . \\
\text { adolescentis }\end{array}$ & End-point & $\begin{array}{c}\text { Bonjoch et al., } \\
2004\end{array}$ \\
\hline Human & Bifidobacteria & Bifidobacteria & $\begin{array}{l}\text { 16S rRNA } B \text {. } \\
\text { adolescentis }\end{array}$ & TaqMan & $\begin{array}{l}\text { Gourmelon et } \\
\text { al., } 2010\end{array}$ \\
\hline
\end{tabular}




\begin{tabular}{|c|c|c|c|c|c|}
\hline Animal Group & Target Organism & Common Target Name & Specific Gene Target & Chemistry & Reference \\
\hline Human & Enterococcus & esp & $\begin{array}{c}\text { esp (enterococcus } \\
\text { surface protein) from } \\
\text { E. faecium }\end{array}$ & End-point & $\begin{array}{l}\text { Scott et al., } \\
2005\end{array}$ \\
\hline Human & Enterococcus & esp & $\begin{array}{c}\text { esp (enterococcus } \\
\text { surface protein) from } \\
\text { E. faecium }\end{array}$ & SYBR & $\begin{array}{l}\text { Ahmed et al., } \\
2008\end{array}$ \\
\hline Ruminant & Bacteroidales & CF193 & $\begin{array}{c}\text { 16S rRNA } \\
\text { Bacteroides-Prevotella } \\
\text { group }\end{array}$ & End-point & $\begin{array}{l}\text { Bernhard and } \\
\text { Field, } 2000\end{array}$ \\
\hline Ruminant & Bacteroidales & Rum2Bac & $\begin{array}{c}\text { 16S rRNA } \\
\text { Bacteroidales }\end{array}$ & TaqMan & $\begin{array}{c}\text { Mieszkin et al., } \\
2010\end{array}$ \\
\hline Ruminant & Bacteroidales & BacR & $\begin{array}{c}\text { 16S rRNA } \\
\text { Bacteroidetes }\end{array}$ & TaqMan & $\begin{array}{c}\text { Reischer et al., } \\
2006\end{array}$ \\
\hline Ruminant & Bacteroidales & CowM2 & $\begin{array}{l}\text { Energy metabolism } \\
\text { genes from } \\
\text { Bacteroidales-like } \\
\text { organisms }\end{array}$ & End-point & $\begin{array}{l}\text { Shanks et al., } \\
2006\end{array}$ \\
\hline Ruminant & Bacteroidales & CowM2 & $\begin{array}{c}\text { Secretory protein from } \\
\text { Bacteroidales-like } \\
\text { organisms }\end{array}$ & TaqMan & $\begin{array}{l}\text { Shanks et al., } \\
2008\end{array}$ \\
\hline Ruminant & Bacteroidales & CowM3 & $\begin{array}{l}\text { Energy metabolism } \\
\text { genes from } \\
\text { Bacteroidales-like } \\
\text { organisms }\end{array}$ & End-point & $\begin{array}{l}\text { Shanks et al., } \\
2006\end{array}$ \\
\hline Ruminant & Bacteroidales & CowM3 & $\begin{array}{c}\text { Secretory protein from } \\
\text { Bacteroidales-like } \\
\text { organisms }\end{array}$ & TaqMan & $\begin{array}{l}\text { Shanks et al., } \\
2008\end{array}$ \\
\hline Porcine & Bacteroidales & PF163 & $\begin{array}{c}\text { 16S rRNA Prevotella } \\
\text { group }\end{array}$ & End-Point & $\begin{array}{c}\text { Dick et al., } \\
2005\end{array}$ \\
\hline Porcine & Bacteroidales & Pig2Bac & $\begin{array}{c}\text { 16S rRNA } \\
\text { Bacteroidales }\end{array}$ & TaqMan & $\begin{array}{c}\text { Mieszkin et al., } \\
2009\end{array}$ \\
\hline Avian & Helicobacter & GFD & $\begin{array}{c}\text { 16S rRNA } \\
\text { Helicobacter spp. }\end{array}$ & SYBR & $\begin{array}{l}\text { Green et al., } \\
\quad 2012\end{array}$ \\
\hline Avian & Brevibacterium & LA35 & $\begin{array}{c}\text { 16S rRNA } \\
\text { Brevibacterium spp. }\end{array}$ & SYBR & $\begin{array}{l}\text { Weidhaas et } \\
\text { al., } 2010\end{array}$ \\
\hline Avian & Catelicoccus & Gull2 & $\begin{array}{c}\text { 16S rRNA } \\
\text { Catelicoccus spp. }\end{array}$ & TaqMan & $\begin{array}{l}\text { Ryu et al., } \\
2012\end{array}$ \\
\hline
\end{tabular}

\subsubsection{Human-associated MST methods}

The presence of human faecal pollution from sewage outfalls, urban run-off, combined sewer overflows, faulty septic systems, and illicit dumping remains a public health risk worldwide. Technologies that can discriminate human faecal waste from other animal sources can provide water quality managers and health officials with valuable information to mitigate impaired waters. Because human waste has the potential to introduce a number of harmful pathogens into environmental waters, there is a wide range of MST technologies available to characterize this source of pollution. Human-associated MST methods presented below target bacterial genetic markers from Bacteroidales, methanogens, Bifidobacterium spp., and Enterococcus taxonomic groups.

\subsubsection{Bacteroidales}

Genetic markers from Bacteroides, a genus within the Bacteroidales order are described in this section. The most widely used human-associated MST methods target the 16S rRNA gene cluster associated with Bacteroides doreii, called HF183 (Haugland et al., 2010). Since the publication of an end-point PCR assay using primers HF183/708R in 2000 (Bernhard and Field, 2000), the method has been modified for SYBR Green and TaqMan real-time quantitative PCR (qPCR) chemistries (Haugland et al., 2010; Seurinck et al., 2005). The widespread use of the HF183/BFDrev TaqMan qPCR technology and performance in multiple validation studies (Boehm et al., 2013) led a team of scientists to develop an improved method, HF183/BacR287 (Green et al., 2014). In head-to-head experiments (HF183/BFDrev versus HF183/BacR287), HF183/BacR287 was reported to exhibit increased 
precision and an improved limit of detection in sewage samples (Green et al., 2014). Other qPCR assays targeting B. doreii are available including BacH (Reischer et al., 2007) and BacHum-UCD (Kildare et al., 2007). Not all Bacteroides spp. human-associated MST methods target 16S rRNA genes. Some scientists assert that chromosomal genes directly involved in bacterium-host interactions harbor sufficient genetic variation for use as MST genetic markers (Shanks et al., 2006, 2009; Yampara-Iquise et al., 2008). Two popular qPCR TaqMan assays target the $B$. thetaiotamicron 1,6-alpha mannanase gene (YamparaIquise et al., 2008) and a Bacteroides-like hypothetical protein (HumM2) (Shanks et al., 2009).

\subsubsection{Methanogens}

Methanobrevibacter smithii is the only Methanobrevibacter species reported to specifically colonize the human intestinal tract (Miller et al., 1984). Two assays are available that target the nifH gene including end-point PCR (Ufnar et al., 2006) and qPCR (Johnston et al., 2010) procedures.

\subsubsection{Bifidobacterium}

Bifidobacteria are an anaerobic group of microorganisms that are abundant in the gastrointestinal tract of humans and other animals (Bahaka et al., 1993; Matsuki et al., 1999). A multiplex end-point PCR assay targeting 16S rRNA genes from B. adolescentis (ADO) and B. dentium (DEN) are available (Bonjoch et al., 2004). In addition, a TaqMan qPCR assay is reported (Gourmelon et al., 2010).

\subsubsection{Enterococcus}

Like the bacterial groups described above, enterococci are inhabitants of the gastrointestinal tract of humans and many other animals. Some species of enterococci (e.g. E. faecium) are reported to be more closely associated with human gastrointestinal tracts and therefore are a potential target for the development of MST methods. An end-point PCR assay targeting the Enterococcus surface protein (esp) is available (Scott et al., 2005). This PCR method was later adapted to a SYBR Green qPCR chemistry (Ahmed et al., 2008).

\subsubsection{Ruminant-associated MST methods}

Ruminants are mammals that are able to digest plantbased food via fermentation using a specialized fourcompartment stomach. There are roughly 150 known species of ruminants worldwide including domestic and wild species such as cattle, goats, sheep, and deer. It is estimated that exposure to waterborne pathogens originating from some ruminant faecal waste, such as cattle, can have a similar public health risk compared to human faecal pollution sources (Soller et al., 2010). As a result, scientists have developed a number of MST methods designed to identify ruminant faecal waste. Selected methods presented below all target microorganisms from the Bacteroidales order. In 2000, the CF193 end-point PCR method was developed targeting 16S rRNA genes from the
Bacteroides-Prevotella group (Bernhard and Field, 2000). Several years later, two TaqMan qPCR methods were reported including Rum2Bac (Mieszkin et al., 2010) and BacR (Reischer et al., 2006) both targeting Bacteroidales 16S rRNA genes. The large number of domesticated cattle worldwide combined with high volume waste production (average adult cow produces 50-80 pounds of waste/day) (Kellogg et al., 2000) suggests that faecal pollution from this ruminant animal group, in particular, can be a significant public health risk. As a result, researchers have developed cattle-associated TaqMan qPCR methods including CowM2 and CowM3, which target chromosomal genes from Bacteroidales-like organisms (Shanks et al., 2006, 2008).

\subsubsection{Porcine-associated MST methods}

Increased swine farming operations represent another potential risk to nearby environmental waters in many countries worldwide. When swine faecal waste is introduced to water, it can pose a risk to human health due to the presence of a variety of human pathogens. To help characterize the impact of swine agricultural practices, scientists have developed several MST methods designed to identify porcine faecal pollution. Available methods target the 16S rRNA genes from Prevotella spp. from the Bacteroidales order including the PF163 end-point assay (Dick et al., 2005) and the qPCR Pig2Bac (Mieszkin et al., 2009).

\subsubsection{Avian-associated MST methods}

Faecal contamination from avian species (e.g. poultry, gulls, Canada geese, ducks, and other birds) can also negatively impact water quality. Avian faeces can contain high concentrations of general faecal indicators such as faecal coliforms, enterococci, and E. coli. Bacterial pathogens such as Salmonella and Campylobacter frequently occur in avian faeces, although exposure to poultry waste has been estimated to be somewhat lower risk than exposure to human and cattle sources (Soller et al., 2010). Several avian-associated MST methods are available, although there is currently no known assay that can detect pollution from all bird species. Methods presented below target 16S rRNA genes from Helicobacter spp. (GFD) (Green et al., 2012), Catelicoccus spp. (Gull4) (Ryu et al., 2012), and Brevibacterium spp. (LA35) (Weidhaas et al., 2010).

\subsection{Detection Technologies}

Common FIB and MST method technologies can be organized into two groups: cultivation methods and molecular methods. Cultivation methods measure the ability of select bacteria to grow under specific conditions and/or express certain enzymes in the presence of a growth medium, which may be selective and/or differential. Molecular methods detect and/or estimate the concentration of genetic markers, typically the 16S rRNA gene, a highly conserved region of bacterial genomes. 


\subsection{Cultivation Methods}

FIB cultivation methods rely on the growth of target microorganism under selective conditions. Selective media contains ingredients that inhibit the growth of non-target microorganisms, while differential media contains ingredients that discriminate microorganisms based on a particular metabolic characteristic. Some media also include ingredients to measure the activity of enzymes used by FIB to break down certain carbohydrates into sugars (e.g. detection of E. coli based on the activity of $\beta$ glucuronidase for the IDEXX Quanti-Tray method).

The most basic approach for measuring FIB via cultivation methods is the presence-absence test which, if done in replicate with serial dilutions, can be used to estimate the density of FIB in a sample based on most probable number (MPN) statistics. Another cultivation method is the direct count method, where samples are either applied directly to nutrient agar or filtered through a membrane which is then placed on nutrient agar. Colony forming units (CFUs) are counted and expressed as a concentration per unit volume. Cultivation methods are available for the detection and enumeration of coliforms, $E$. coli, and enterococci, and are used in a wide variety of regulatory settings for water quality management. Standardized cultivation methods for the enumeration of clostridia are also available. Bifidobacteria and Bacteroides spp. can also be cultivated, but these methods are seldom used for regulatory purposes.

2.1.1 Presence-absence and endpoint dilution (multiple tube) methods

The multiple tube method consists of a series of presence-absence tests performed on replicates of a single sample at one or more sample dilutions. Some tubes (wells) should show positive growth (which may be observed as turbidity, gas production, or color change from acid production or enzyme activity), while other tubes (wells) will be negative. The average density of bacteria in the original sample is then estimated using the MPN method. Compared to the direct count (membrane filtration method), the MPN method is more labor intensive and less precise; it also tends to overestimate the actual concentrations, especially when a small number of dilutions and replicates are used. Standardized methods for the detection of FIB using presence-absence or quantification using endpoint dilution (multiple tube) methods with MPN statistics are described in APHA (APHA, 2012), ISO (ISO, 1986a, 1986b, 1998, 2000), ASTM (ASTM, 2000), AOAC (AOAC, 1995), the U.S. EPA (USEPA, 2006a, 2006b).

\subsubsection{Direct count (membrane filtration and plating)} methods

For direct count methods, $100 \mathrm{~mL}$ water samples are passed through a membrane, which is transferred to an agar medium and incubated. Discrete colonies with the desired characteristics are then counted after incubation. One of the major challenges of the membrane filtration method is that samples with high turbidity often clog the membrane potentially biasing findings. Nevertheless, the membrane filtration method can be more accurate and precise than the multiple tube method. FIB concentrations are expressed as CFU/volume of sample. Standard methods for the detection of FIB using membrane filtration or direct count techniques are described in APHA (APHA, 2012), ISO (ISO, 1986b, 2000), ASTM (ASTM, 2000), AOAC (AOAC, 1995), the U.S. EPA (USEPA, 2006a, 2006b).

\subsubsection{Indirect measurements of FIB}

Other techniques that measure water quality parameters such as turbidity (Cinque et al., 2004) or $\mathrm{H}_{2} \mathrm{~S}$ concentration (Luyt et al., 2012) have been used to indirectly infer the presence of faecal pollution in water. These tests do not measure FIB directly, but may be useful for assessing water quality in remote locations or in the wake of natural disasters, when laboratories are nonexistent or non-functional. In one study, authors reported the successful application of a field $\mathrm{H}_{2} \mathrm{~S}$ test procedure for field use (Chuang et al., 2011).

\subsection{Molecular Methods}

Molecular methods refer to protocols used in genetics, microbiology, biochemistry, or other related fields to study biologically important molecules such as DNA, RNA, and proteins. Protocols typically include a biological sample collection step followed by molecule isolation and characterization. This section will describe PCR and qPCR molecular methods used to measure FIB and hostassociated DNA gene sequences harbored by faecal bacteria.

\subsubsection{PCR}

PCR is a technique used to amplify a small amount of DNA target originating from a faecal microorganism that is closely associated with the presence of faecal material (FIB) or waste from a particular animal group (hostassociated indicator). A PCR amplification generates millions of copies of the targeted DNA in a matter of hours. The massive number of DNA copies generated by PCR can then be visualized by agarose gel electrophoresis or any other suitable nucleic acid visualization technology. PCR can also be used for RNA targets, such as RNA viruses, using reverse-transcriptase PCR to convert RNA to complementary DNA (cDNA). The presence or absence of a particular DNA or RNA target is used as evidence to infer the existence of faecal pollution from any source (e.g. Bacteroidales, Enterococcus) or from a specific animal group such as human, ruminant, cattle, swine, or avian (host-associated bacteria genetic marker). PCR can be extremely precise, target a specific sequence from a complex mixture of DNA molecules, and provide results in several hours making it ideal for the rapid detection of faecal-associated DNA targets in animal waste and polluted ambient water environments.

PCR is able to amplify a DNA target by mimicking bacterial cell DNA replication in a plastic microtube. Please refer elsewhere for a complete description of the PCR 
principles (Snyder et al., 1997). Briefly, total DNA isolated from a test sample (sewage, faeces, ambient water, etc) is mixed with a heat-stable DNA polymerase, nucleotides, primers, and cations in a buffer solution. PCR amplification is carried out in a series of repeated temperature changes (cycles) in a thermal cycler instrument designed to rapidly heat and cool the reaction mixture. As PCR amplification progresses, the new DNA molecules manufactured serve as template for DNA synthesis in the next cycle, setting in motion a chain reaction where the original DNA target is exponentially amplified. Determination of the presence or absence of faecal contamination in an environmental sample provides water quality managers with valuable information; however, the ability to quantify the concentration of the DNA target can offer additional insights about water impairment patterns and pollution sources.

\subsubsection{Quantitative real-time PCR (qPCR)}

Quantitative real-time PCR (qPCR) is based on PCR where the accumulation of newly synthesized DNA target is measured over the course of amplification. There are two common chemistries employed to detect PCR products in real-time including the use of non-specific fluorescent dyes that intercalate with double stranded DNA (e.g. SYBR), and the addition of a sequence specific DNA probe labelled with a fluorescent reporter molecule that emits energy upon hybridization to a target sequence (e.g. TaqMan). For a detailed description of qPCR principles, please refer to (Bustin, 2006). Briefly, the qPCR process is similar to PCR with the addition of either a fluorescent intercalating dye (SYBR) or labelled probe (TaqMan). Reactions are conducted in a special thermal cycler equipped with a sensor designed to measure the fluorescence emitted from a fluorophore associated with each newly synthesized PCR product. qPCR is based on the theoretical premise that there is a log-linear relationship between the starting amount of DNA target in the reaction and the measured fluorescence value. The concentration of nucleic acid in a sample is determined by comparison to a standard curve.

\subsection{Occurrence in Faecal Pollution Sources}

\subsection{Data on Faecal Indicator Bacteria}

Typical densities of FIB in human faeces, untreated sewage and sewage sludge are summarized in Table 5. Table 6 contains typical densities found in faecal waste from a variety of other animals.

Table 5. Summary of faecal indicator bacteria abundance in common human pollution sources by cultivation methods (Colony forming units, CFUs)

\begin{tabular}{|c|c|c|}
\hline FIB Group & Pollution Source & $\begin{array}{l}\text { Typical Range of Concentrations } \\
\text { (CFU/100mL or per wet g) }\end{array}$ \\
\hline Thermotolerant Coliforms & Faeces (per wet g) & $1.0 \mathrm{E}+06$ to $1.0 \mathrm{E}+09$ \\
\hline Thermotolerant Coliforms & Untreated Sewage (per 100mL) & $1.0 \mathrm{E}+06$ to $1.0 \mathrm{E}+08$ \\
\hline Thermotolerant Coliforms & Sewage Sludge (per wet g) & $1.0 \mathrm{E}+04$ to $1.0 \mathrm{E}+09$ \\
\hline E. coli & Faeces (per wet g) & $1.0 \mathrm{E}+06$ to $1.0 \mathrm{E}+09$ \\
\hline E. coli & Untreated Sewage (per 100mL) & $1.0 \mathrm{E}+07$ to $1.0 \mathrm{E}+08$ \\
\hline E. coli & Sewage Sludge (per wet g) & $1.0 \mathrm{E}+04$ to $1.0 \mathrm{E}+08$ \\
\hline $\begin{array}{l}\text { Enterococci and } \\
\text { Faecal Streptococci }\end{array}$ & Faeces (per wet g) & $1.0 \mathrm{E}+05$ to $1.0 \mathrm{E}+08$ \\
\hline $\begin{array}{l}\text { Enterococci and } \\
\text { Faecal Streptococci }\end{array}$ & Untreated Sewage (per 100mL) & $1.0 \mathrm{E}+05$ to $1.0 \mathrm{E}+07$ \\
\hline $\begin{array}{l}\text { Enterococci and } \\
\text { Faecal Streptococci }\end{array}$ & Sewage Sludge (per wet g) & $1.0 \mathrm{E}+05$ to $1.0 \mathrm{E}+07$ \\
\hline Bacteroides spp. & Faeces (per wet g) & $1.0 \mathrm{E}+08$ to $1.0 \mathrm{E}+10$ \\
\hline Bacteroides spp. & Untreated Sewage (per 100mL) & $1.0 \mathrm{E}+09$ \\
\hline Bifidobacterium spp. & Faeces (per wet g) & $1.0 \mathrm{E}+08$ to $1.0 \mathrm{E}+10$ \\
\hline Bifidobacterium spp. & Untreated Sewage (per 100mL) & $1.0 \mathrm{E}+06$ to $1.0 \mathrm{E}+09$ \\
\hline Clostridium spp. & Faeces (per wet g) & $1.0 \mathrm{E}+03$ \\
\hline Clostridium spp. & Untreated Sewage (per 100mL) & $1.0 \mathrm{E}+04$ to $1.0 \mathrm{E}+06$ \\
\hline Clostridium spp. & Sewage Sludge (per wet g) & $1.0 \mathrm{E}+05$ to $1.0 \mathrm{E}+07$ \\
\hline
\end{tabular}

Sources: (Geldreich, 1978; Feachem et al., 1983; Wang et al., 1996; Ashbolt et al., 2001; Rose et al., 2004; Morrison et al., 2008; Boutilier et al., 2009; Sidhu and Toze, 2009; Silkie and Nelson, 2009; Pillai et al., 2011; WHO, 2011; Zimmer et al., 2012; Akiba et al., 2015) 
Table 6. Summary of typical faecal indicator bacteria concentrations in agricultural and pet animal waste

\begin{tabular}{|c|c|c|c|c|c|}
\hline Pollution Source & $\begin{array}{l}\text { Excretion Rate } \\
\text { (wet g/day) }\end{array}$ & $\begin{array}{c}\text { Moisture } \\
\text { Content (\%) }\end{array}$ & $\begin{array}{l}\text { Target Organism or } \\
\text { Group of Organisms }\end{array}$ & $\begin{array}{c}\text { Average } \\
\text { Concentration }^{\mathrm{a}} \\
\text { (per wet gram) }\end{array}$ & $\begin{array}{c}\text { Average Daily FIB } \\
\text { Excretion Rate } \\
\text { (per wet gram) }\end{array}$ \\
\hline Chicken Faeces & 182 & 71.6 & $\begin{array}{l}\text { Thermotolerant } \\
\text { coliforms }\end{array}$ & $1.3 \mathrm{E}+06$ & $2.37 \mathrm{E}+08$ \\
\hline Chicken Faeces & 182 & 71.6 & Faecal streptococci & $3.4 \mathrm{E}+06$ & $6.19 \mathrm{E}+08$ \\
\hline Chicken Faeces & 182 & 71.6 & C. perfringens & $2.5 \mathrm{E}+02$ & $4.55 \mathrm{E}+04$ \\
\hline Cow Faeces & 23,600 & 83.3 & $\begin{array}{c}\text { Thermotolerant } \\
\text { coliforms }\end{array}$ & $2.3 \mathrm{E}+05$ & $5.43 \mathrm{E}+09$ \\
\hline Cow Faeces & 23,600 & 83.3 & Faecal streptococci & $1.3 \mathrm{E}+06$ & $3.07 \mathrm{E}+10$ \\
\hline Cow Faeces & 23,600 & 83.3 & C. perfringens & $2.0 \mathrm{E}+02$ & $4.72 \mathrm{E}+06$ \\
\hline Duck Faeces & 336 & 61 & $\begin{array}{l}\text { Thermotolerant } \\
\text { coliforms }\end{array}$ & $3.3 \mathrm{E}+07$ & $1.11 \mathrm{E}+10$ \\
\hline Duck Faeces & 336 & 61 & Faecal streptococci & $5.4 \mathrm{E}+07$ & $1.81 \mathrm{E}+10$ \\
\hline Horse Faeces & 20,000 & $\mathrm{NR}^{\mathrm{b}}$ & $\begin{array}{l}\text { Thermotolerant } \\
\text { coliforms }\end{array}$ & $1.26 \mathrm{E}+04$ & $2.52 \mathrm{E}+08$ \\
\hline Horse Faeces & 20,000 & NR & Faecal streptococci & $6.3 \mathrm{E}+06$ & $1.26 \mathrm{E}+11$ \\
\hline Horse Faeces & 20,000 & NR & C. perfringens & $<1$ & $<2.0 \mathrm{E}+04$ \\
\hline Sheep Faeces & 1,130 & 74.4 & $\begin{array}{l}\text { Thermotolerant } \\
\text { coliforms }\end{array}$ & $1.6 \mathrm{E}+07$ & $1.81 \mathrm{E}+10$ \\
\hline Sheep Faeces & 1,130 & 74.4 & Faecal streptococci & $3.8 \mathrm{E}+07$ & $4.29 \mathrm{E}+10$ \\
\hline Sheep Faeces & 1,130 & 74.4 & C. perfringens & $1.99 \mathrm{E}+05$ & $2.25 \mathrm{E}+08$ \\
\hline Swine Faeces & 2,700 & 66.7 & $\begin{array}{l}\text { Thermotolerant } \\
\text { coliforms }\end{array}$ & $3.3 \mathrm{E}+06$ & $8.91 \mathrm{E}+09$ \\
\hline Swine Faeces & 2,700 & 66.7 & Faecal streptococci & $8.4 \mathrm{E}+07$ & $2.27 \mathrm{E}+11$ \\
\hline Swine Faeces & 2,700 & 66.7 & C. perfringens & $3.98 \mathrm{E}+03$ & $1.07 \mathrm{E}+07$ \\
\hline Turkey Faeces & 448 & 62 & $\begin{array}{l}\text { Thermotolerant } \\
\text { coliforms }\end{array}$ & $2.9 \mathrm{E}+05$ & $1.3 \mathrm{E}+08$ \\
\hline Turkey Faeces & 448 & 62 & Faecal streptococci & $2.8 \mathrm{E}+06$ & $1.25 E+09$ \\
\hline Cat Faeces & Not applicable & NR & $\begin{array}{l}\text { Thermotolerant } \\
\text { coliforms }\end{array}$ & $7.9 \mathrm{E}+06$ & NR \\
\hline Cat Faeces & Not applicable & NR & Faecal streptococci & $2.7 \mathrm{E}+07$ & NR \\
\hline Cat Faeces & Not applicable & NR & C. perfringens & $2.51 \mathrm{E}+07$ & NR \\
\hline Dog Faeces & 413 & NR & $\begin{array}{c}\text { Thermotolerant } \\
\text { coliforms }\end{array}$ & $2.3 \mathrm{E}+07$ & $9.5 \mathrm{E}+09$ \\
\hline Dog Faeces & 413 & NR & Faecal streptococci & $9.8 \mathrm{E}+08$ & $4.05 \mathrm{E}+11$ \\
\hline Dog Faeces & 413 & NR & C. perfringens & $2.51 \mathrm{E}+08$ & $1.04 \mathrm{E}+11$ \\
\hline
\end{tabular}

Adapted from (Geldreich, 1978; Ashbolt et al., 2001); ${ }^{a}$ CFU: Colony forming unit; ${ }^{b}$ NR: Not reported

\subsubsection{Human excreta}

Bacteroides spp. and Bifidobacterium spp. are typically present in human faeces in higher quantities compared to Clostridium spp., enterococci, E. coli and other coliforms. Enterococci, E. coli, and other members of the coliform group are reported to only account for $7 \%$ of the total bacterial ribosomal RNA in human faecal samples (Guarner and Malagelada, 2003).

FIB concentrations in human faeces are highly variable among individuals, and can vary across geographic regions due to many factors, including dietary differences. For example, the densities of Bacteroides spp., Bifidobacterium spp., E. coli, and members of the family Enterobacteriaceae are significantly lower in vegans than they are for people with omnivorous diets (Zimmer et al., 2012). The relative proportions of FIB bacteria populations in human faeces can also vary based on health. For example, Khachatryan and colleagues reported significantly higher proportions of Bacteroides in faecal samples from a subset of patients with Crohn's disease and familial Mediterranean fever relative to healthy patients (Khachatryan et al., 2008). Larsen and co-workers (2010) found that the proportions of Clostridia in faecal samples from patients with type 2 diabetes were significantly lower than they were in samples from a control 
group (Larsen et al., 2010), while another research group reported higher overall microbial diversity with lower quantities of Bifidobacterium spp. in faecal samples from children with autism relative to a control group (De Angelis et al., 2013).

Human urine should not contain FIB, although coliforms (including E. coli), Clostridia, and faecal streptococci have been detected in urine collection tanks from sourceseparated sewage systems. Cross-contamination with faecal matter has been implicated in contamination levels estimated at $9.1 \mathrm{mg}$ faeces/L urine, with densities of faecal streptococci as high as 105/mL (Hoglund et al., 1998; Schonning et al., 2002).

\subsubsection{Untreated sewage}

Sewage contains human waste that has been diluted with flushing water. Depending on the region, sewage may also contain greywater from sinks, showers, and laundry (washing clothes). Because of this, the relative densities of FIB can vary greatly depending on the nature of the facilities and residences discharging to the local sewer collection system. In a study of six wastewater facilities in the United States receiving mostly domestic wastewater (Harwood et al., 2005), concentrations of total coliforms in untreated sewage (geometric mean: $3.3 \times 10^{7} \mathrm{CFU} / 100 \mathrm{~mL}$ ) were greater than concentrations of thermotolerant coliforms (geometric mean: $3.4 \times 10^{6} \mathrm{CFU} / 100 \mathrm{~mL}$ ), which were greater than concentrations of enterococci (geometric mean: $\left.9.4 \times 10^{5} \mathrm{CFU} / 100 \mathrm{~mL}\right) ; C$. perfringens was only detected sporadically at quantities that were two or more orders of magnitude lower than coliforms. A study of 166 wastewater facilities in Brazil (Oliveira and von Sperling, 2011) revealed greater concentrations of thermotolerant coliforms in untreated sewage (geometric mean values ranged from $2.6 \times 10^{7}$ to $2.0 \times 10^{8} \mathrm{MPN} / 100 \mathrm{~mL}$ ). Similarly, high concentrations of thermotolerant coliforms have been reported in Bolivian wastewater $\left(3.5 \times 10^{7} \mathrm{MPN} / 100 \mathrm{~mL}\right)$ (Zabalaga et al., 2007). However, thermotolerant coliform concentrations reported in untreated sewage from the treatment plants serving 15 cities in India $\left(4.0 \times 10^{5}\right.$ to 9.2 $\left.\times 10^{6} \mathrm{MPN} / 100 \mathrm{~mL}\right)($ Sato et al., 2006) were more comparable to the values reported in the United States by Rose et al.(Harwood et al., 2005).

Concentrations of obligately anaerobic FIB Bacteroides spp. and Bifidobacterium spp. in untreated sewage are not reported as frequently in the literature; however, the concentration of Bifidobacterium spp. in untreated sewage (based on cultivation on HBSA medium (Mara and Oragui,
1983) has been reported as $4.0 \times 10^{6} \mathrm{CFU} / 100 \mathrm{~mL}$ (Ottoson, 2009).

\subsection{Data on Host-Associated MST Methods}

The occurrence of host-associated bacterial MST genetic markers in target and non-target pollution sources is typically reported as sensitivity (target sources), specificity (non-target sources), and for qPCR methods, it is common to also include genetic marker concentrations (gene copies per volume, mass, or cell count). Sensitivity is routinely expressed as the following: sensitivity = TPC/(TBC+TNI), where TPC represents the total number of samples that tested positive correctly and TNI denotes the total number of samples that tested incorrectly. Specificity is typically defined as the total number of samples that test negative correctly (TNC) divided by the sum of TNC and the total number of samples that tested positive incorrectly (TPI) or TNC/(TNC+TPI). Occurrence data are generated by systematic testing of reference samples from known pollution sources usually collected in close proximity to the research laboratory performing MST experiments. A rapidly growing interest in the application of MST methods has led to testing reference samples collected from a broader range of geographic locations. This section seeks to organize and report MST genetic marker occurrence data reported from reference sample collections across the globe.

\subsubsection{Occurrence of host-associated MST genetic markers in common pollution types}

A useful MST method should measure a genetic marker that is widely dispersed across the target population of interest that is absent or occurs at a significantly lower concentration in non-target pollution sources present in the study area. The occurrence of host-associated MST genetic markers [sensitivity and concentration (gene copies per volume, mass, or cell count)] has been reported in more than 20 countries to date providing valuable information for researchers and water quality managers. Human-associated MST genetic marker occurrence data is organized by pollution type including sewage (Table 7), faecal (Table 8), and onsite sources (Table 9). Other non-human hostassociated occurrence data is shown for ruminant, porcine, and avian MST methods (Table 10 and 11). Summarized data are presented by MST methodology and geographic origin of reference pollution source materials. Only studies reporting genetic marker concentrations in gene copies are shown. For a more detailed description of MST method genetic marker occurrence, please refer to Appendix A.

Table 7. Summary of human-associated MST method target occurrence in sewage

\begin{tabular}{|c|c|c|c|c|c|}
\hline Area & Common Target Name & $\begin{array}{c}\text { Number of } \\
\text { samples }\end{array}$ & Sensitivity $^{\mathrm{a}}$ & $\begin{array}{l}\text { Gene Copy Concentration } \\
\text { (Mean or Range) per } 100 \mathrm{~mL}\end{array}$ & Reference \\
\hline \multicolumn{6}{|c|}{ SYBR } \\
\hline Australia & HF183 & 32 & $100 \%$ & $\mathrm{NR}^{\mathrm{b}}$ & $\begin{array}{c}\text { Ahmed et al., } \\
2009\end{array}$ \\
\hline
\end{tabular}




\begin{tabular}{|c|c|c|c|c|c|}
\hline Area & Common Target Name & $\begin{array}{c}\text { Number of } \\
\text { samples }\end{array}$ & Sensitivity $^{\mathrm{a}}$ & $\begin{array}{l}\text { Gene Copy Concentration } \\
\text { (Mean or Range) per } 100 \mathrm{~mL}\end{array}$ & Reference \\
\hline Australia & HF183 & 99 & $100 \%$ & $\begin{array}{c}8.0 \mathrm{E}+03 \\
\text { gene copies } / 100 \mathrm{~mL}\end{array}$ & $\begin{array}{l}\text { Ahmed et al., } \\
2015\end{array}$ \\
\hline Belgium & HF183 & 4 & $100 \%$ & $\begin{array}{l}5.9 \mathrm{E}+09 \text { to } 3.1 \mathrm{E}+10 \\
\text { gene copies/100mL }\end{array}$ & $\begin{array}{l}\text { Seurinck et al., } \\
2005\end{array}$ \\
\hline India & HF183 & 5 & $100 \%$ & $\begin{array}{c}47\left( \pm 0.47 \log _{10}\right) \\
\text { gene copies/ng of total DNA }\end{array}$ & $\begin{array}{l}\text { Odagiri et al., } \\
2015\end{array}$ \\
\hline USA & HF183 & 16 & $100 \%$ & NR & $\begin{array}{l}\text { Layton et al., } \\
2013\end{array}$ \\
\hline USA & HF183 & 10 & $100 \%$ & $\begin{array}{l}4.0 \mathrm{E}+08 \text { to } 2.5 \mathrm{E}+10 \\
\text { gene copies } / 100 \mathrm{~mL}\end{array}$ & $\begin{array}{l}\text { Van De Werfhorst } \\
\text { et al., } 2011\end{array}$ \\
\hline Australia & esp & 16 & $100 \%$ & $\begin{array}{l}9.8 \mathrm{E}+03 \text { to } 3.8 \mathrm{E}+04 \\
\text { gene copies/100mL }\end{array}$ & $\begin{array}{l}\text { Ahmed et al., } \\
2008\end{array}$ \\
\hline Australia & esp & 10 & $100 \%$ & NR & $\begin{array}{l}\text { Ahmed et al., } \\
2009\end{array}$ \\
\hline \multicolumn{6}{|c|}{ TaqMan } \\
\hline India & HF183 & 5 & $100 \%$ & $\begin{array}{c}195\left( \pm 0.72 \log _{10}\right) \\
\text { gene copies/ng of total DNA }\end{array}$ & $\begin{array}{l}\text { Odagiri et al., } \\
2015\end{array}$ \\
\hline USA & HF183 & 20 & 85 to $100 \%$ & NR & $\begin{array}{l}\text { Layton et al., } \\
2013\end{array}$ \\
\hline USA & HF183 & 14 & $100 \%$ & $\begin{array}{c}630 \\
\text { gene copies/ng of total DNA }\end{array}$ & $\begin{array}{l}\text { Haugland et al., } \\
\qquad 2010\end{array}$ \\
\hline Austria & $\mathrm{BacH}$ & 20 & $100 \%$ & $\begin{array}{l}1.4 \mathrm{E}+10 \text { to } 9.1 \mathrm{E}+10 \\
\text { gene copies/g }\end{array}$ & $\begin{array}{l}\text { Reischer et al., } \\
2007\end{array}$ \\
\hline India & $\mathrm{BacH}$ & 5 & $40 \%$ & $\begin{array}{l}107\left( \pm 0.35 \log _{10}\right) \\
\text { gene copies/ng of total DNA }\end{array}$ & $\begin{array}{l}\text { Odagiri et al., } \\
2015\end{array}$ \\
\hline USA & $\mathrm{BacH}$ & 4 & 50 to $100 \%$ & NR & $\begin{array}{l}\text { Layton et al., } \\
2013\end{array}$ \\
\hline USA & BacHum-UCD & 24 & $92 \%$ & NR & $\begin{array}{l}\text { Layton et al., } \\
2013\end{array}$ \\
\hline USA & BacHum-UCD & 10 & $100 \%$ & $\begin{array}{l}6.0 \mathrm{E}+08 \text { to } 8.5 \mathrm{E}+10 \\
\text { gene copies/100mL }\end{array}$ & $\begin{array}{l}\text { Van De Werfhorst } \\
\text { et al., } 2011\end{array}$ \\
\hline USA & BacHum-UCD & 14 & $100 \%$ & NR & $\begin{array}{l}\text { Kildare et al., } \\
2007\end{array}$ \\
\hline USA & BacHum-UCD & 12 & $100 \%$ & $\begin{array}{c}7.9 \mathrm{E}+08 \\
\text { gene copies } / 100 \mathrm{~mL}\end{array}$ & $\begin{array}{l}\text { Silkie and Nelson, } \\
2009\end{array}$ \\
\hline USA & BacHum-UCD & 5 & $100 \%$ & $\begin{array}{c}178\left( \pm 0.75 \log _{10}\right) \\
\text { gene copies/ng of total DNA }\end{array}$ & $\begin{array}{l}\text { Odagiri et al., } \\
2015\end{array}$ \\
\hline India & HumM2 & 54 & $100 \%$ & $\begin{array}{c}63 \text { to } 3.16 \mathrm{E}+03 \\
\text { gene copies/ng of DNA }\end{array}$ & $\begin{array}{l}\text { Shanks et al., } \\
2010\end{array}$ \\
\hline USA & HumM2 & 24 & 46 to $83 \%$ & NR & $\begin{array}{l}\text { Layton et al., } \\
\quad 2013\end{array}$ \\
\hline USA & HumM2 & 20 & $100 \%$ & $\begin{array}{c}631 \\
\text { gene copies/ng of total DNA }\end{array}$ & $\begin{array}{l}\text { Shanks et al., } \\
2009\end{array}$ \\
\hline France & B. adolescentis & 8 & $100 \%$ & $\begin{array}{l}1.0 \mathrm{E}+04 \text { to } 7.9 \mathrm{E}+06 \\
\text { gene copies/100mL }\end{array}$ & $\begin{array}{l}\text { Gourmelon et al., } \\
2010\end{array}$ \\
\hline USA & 1,6-alpha mannanase & 4 & 75 to $100 \%$ & NR & $\begin{array}{l}\text { Layton et al., } \\
2013\end{array}$ \\
\hline USA & 1,6-alpha mannanase & 20 & $100 \%$ & $\begin{array}{c}13.4 \text { to } 457 \\
\text { gene copies/ng of total DNA }\end{array}$ & $\begin{array}{l}\text { Yampara-Iquise et } \\
\text { al., } 2008\end{array}$ \\
\hline USA & 1,6-alpha mannanase & 54 & $100 \%$ & 1.82 E+07 gene copies/100mL & $\begin{array}{c}\text { Srinivasan et al., } \\
2011\end{array}$ \\
\hline USA & nifH & 20 & 20 to $55 \%$ & NR & $\begin{array}{l}\text { Layton et al., } \\
2013\end{array}$ \\
\hline USA & nifH & 16 & $100 \%$ & $\begin{array}{l}12 \text { to } 3.8 \mathrm{E}+03 \\
\text { gene copies/100mL }\end{array}$ & $\begin{array}{l}\text { Johnston et al., } \\
2010\end{array}$ \\
\hline \multicolumn{6}{|c|}{ End-point $^{\mathrm{c}}$} \\
\hline
\end{tabular}




\begin{tabular}{|c|c|c|c|c|c|}
\hline Area & Common Target Name & $\begin{array}{c}\text { Number of } \\
\text { samples }\end{array}$ & Sensitivity $^{a}$ & $\begin{array}{l}\text { Gene Copy Concentration } \\
\text { (Mean or Range) per } 100 \mathrm{~mL}\end{array}$ & Reference \\
\hline Australia & HF183 & 45 & $100 \%$ & NR & $\begin{array}{l}\text { Ahmed et al., } \\
2008\end{array}$ \\
\hline Canada & HF183 & 8 & $100 \%$ & NR & $\begin{array}{l}\text { Fremaux et al., } \\
2009\end{array}$ \\
\hline Canada & HF183 & 102 & $74 \%$ & NR & Edge et al., 2013 \\
\hline France & HF183 & 5 & $100 \%$ & NR & $\begin{array}{l}\text { Gourmelon et al., } \\
2007\end{array}$ \\
\hline Spain & HF183 & 40 & $50 \%$ & NR & $\begin{array}{l}\text { Balleste et al., } \\
2010\end{array}$ \\
\hline USA & HF183 & 3 & $100 \%$ & NR & $\begin{array}{l}\text { Bernhard and } \\
\text { Field, } 2000\end{array}$ \\
\hline USA & HF183 & 28 & $57 \%$ & NR & $\begin{array}{l}\text { Layton et al., } \\
2013\end{array}$ \\
\hline USA & HF183 & 54 & $100 \%$ & NR & $\begin{array}{l}\text { Shanks et al., } \\
2010\end{array}$ \\
\hline USA & HF183 & 16 & $75 \%$ & NR & $\begin{array}{l}\text { Toledo-Hernandez } \\
\text { et al., } 2013\end{array}$ \\
\hline USA & HF183 & 39 & $100 \%$ & NR & $\begin{array}{l}\text { McQuaig et al., } \\
2009\end{array}$ \\
\hline USA & HF183 & 48 & $100 \%$ & NR & $\begin{array}{l}\text { Harwood et al., } \\
2009\end{array}$ \\
\hline France & nifH & 8 & $100 \%$ & $\begin{array}{c}1.0 \mathrm{E}+04 \text { to } 7.9 \mathrm{E}+06 \text { gene } \\
\text { copies } / 100 \mathrm{~mL}\end{array}$ & $\begin{array}{l}\text { Gourmelon et al., } \\
2010\end{array}$ \\
\hline USA & nifH & 39 & $100 \%$ & NR & $\begin{array}{c}\text { McQuaig et al., } \\
2009\end{array}$ \\
\hline USA & nifH & 19 & $100 \%$ & NR & $\begin{array}{l}\text { Harwood et al., } \\
2009\end{array}$ \\
\hline USA & nifH & 27 & $93 \%$ & NR & Ufnar et al., 2006 \\
\hline USA & nifH & 20 & 20 to $55 \%$ & NR & $\begin{array}{l}\text { Layton et al., } \\
2013\end{array}$ \\
\hline Spain & B. adolescentis & 45 & $95.6 \%$ & NR & $\begin{array}{l}\text { Balleste et al,. } \\
\quad 2010\end{array}$ \\
\hline Spain & B. adolescentis & 12 & $100 \%$ & NR & $\begin{array}{c}\text { Bonjoch et al., } \\
2004\end{array}$ \\
\hline $\begin{array}{l}\text { Spain, } \\
\text { France, } \\
\text { Sweden, } \\
\text { UK, } \\
\text { Cyprus, } \\
\text { USA }\end{array}$ & B. adolescentis & 114 & $92.7 \%$ & NR & $\begin{array}{l}\text { Blanch et al., } \\
2006\end{array}$ \\
\hline USA & B. adolescentis & 3 & $66.6 \%$ & NR & $\begin{array}{l}\text { Bachoon et al., } \\
2010\end{array}$ \\
\hline Australia & esp & Not known & $100 \%$ & NR & Neave et al., 2014 \\
\hline Spain & esp & 13 & $77 \%$ & NR & $\begin{array}{l}\text { Balleste et al,. } \\
2010\end{array}$ \\
\hline USA & esp & 26 & $92 \%$ & NR & $\begin{array}{l}\text { Layton et al., } \\
2009\end{array}$ \\
\hline USA & esp & 55 & $100 \%$ & NR & $\begin{array}{l}\text { Reischer et al., } \\
2006\end{array}$ \\
\hline USA & esp & 3 & $100 \%$ & NR & $\begin{array}{l}\text { Korajkic et al., } \\
2009\end{array}$ \\
\hline USA & esp & 20 & $55 \%$ & NR & $\begin{array}{c}\text { Masago et al., } \\
2011\end{array}$ \\
\hline
\end{tabular}


${ }^{a}$ Sensitivity is routinely expressed as the following: sensitivity $=$ TPC/(TBC+TNI), where TPC represents the total number of samples that tested positive correctly and TNI denotes the total number of samples that tested incorrectly. Specificity is typically defined as the total number of samples that test negative correctly (TNC) divided by the sum of TNC and the total number of samples that tested positive incorrectly (TPI) or TNC/(TNC+TPI);

${ }^{\mathrm{b}} \mathrm{NR}$ : Not reported; ${ }^{\mathrm{c} e n d p o i n t ~ i s ~ a ~ n o n-q u a n t i t a t i v e ~ m e t h o d ~}$

Table 8. Summary of human-associated MST method target occurrence in faeces

\begin{tabular}{|c|c|c|c|c|c|}
\hline Area & Common Target Name & $\begin{array}{l}\text { Number of } \\
\text { samples }\end{array}$ & Sensitivity $^{a}$ & $\begin{array}{l}\text { Gene Copy Concentration } \\
\text { (Mean or Range) }\end{array}$ & Reference \\
\hline \multicolumn{6}{|c|}{ SYBR } \\
\hline Belgium & HF183 & 7 & $85.7 \%$ & $\begin{array}{l}8.4 \mathrm{E}+05 \text { to } 7.2 \mathrm{E}+09 \\
\text { gene copies/g }\end{array}$ & $\begin{array}{l}\text { Seurinck et al., } \\
2005\end{array}$ \\
\hline Bangladesh & HF183 & 15 & $87 \%$ & $\begin{array}{l}1.2 \mathrm{E}+05 \text { to } 3.9 \mathrm{E}+07 \\
\text { gene copies/g }\end{array}$ & $\begin{array}{l}\text { Ahmed et al., } \\
2010\end{array}$ \\
\hline India & HF183 & 30 & $86.7 \%$ & $\begin{array}{l}9\left( \pm 1.64 \log _{10}\right) \\
\text { gene copies/ng } \\
\text { of total DNA }\end{array}$ & $\begin{array}{l}\text { Odagiri et al., } \\
2015\end{array}$ \\
\hline USA & HF183 & 16 & $100 \%$ & $\mathrm{NR}^{\mathrm{b}}$ & $\begin{array}{l}\text { Layton et al., } \\
2013\end{array}$ \\
\hline USA & HF183 & 8 & $62.5 \%$ & $\begin{array}{l}4.9 \mathrm{E}+03 \text { to } 5.3 \mathrm{E}+08 \\
\text { gene copies/g }\end{array}$ & $\begin{array}{l}\text { Van De } \\
\text { Werfhorst et } \\
\text { al., } 2011\end{array}$ \\
\hline \multicolumn{6}{|c|}{ TaqMan } \\
\hline India & & 30 & $16.7 \%$ & $\begin{array}{c}204\left( \pm 1.71 \log _{10}\right) \\
\text { gene copies/ng } \\
\text { of total DNA }\end{array}$ & $\begin{array}{l}\text { Odagiri et al., } \\
2015\end{array}$ \\
\hline USA & HF183 & 20 & $100 \%$ & NR & $\begin{array}{l}\text { Layton et al., } \\
2013\end{array}$ \\
\hline USA & HF183 & 16 & $100 \%$ & $\begin{array}{c}1.47 \mathrm{E}+03\left( \pm 0.07 \log _{10}\right) \text { gene } \\
\text { copies/ng } \\
\text { of total DNA }\end{array}$ & $\begin{array}{l}\text { Haugland et } \\
\text { al., } 2010\end{array}$ \\
\hline Austria & $\mathrm{BacH}$ & 21 & $95 \%$ & $\begin{array}{l}6.6 \mathrm{E}+09 \text { to } 9.1 \mathrm{E}+10 \\
\text { gene copies/g }\end{array}$ & $\begin{array}{l}\text { Johnston et al., } \\
2010\end{array}$ \\
\hline Austria & $\mathrm{BacH}$ & 4 & $100 \%$ & NR & $\begin{array}{l}\text { Reischer et al., } \\
2013\end{array}$ \\
\hline India & $\mathrm{BacH}$ & 30 & $13.3 \%$ & $\begin{array}{l}251\left( \pm 0.97 \log _{10}\right) \\
\text { gene copies/ng } \\
\text { of total DNA }\end{array}$ & $\begin{array}{l}\text { Odagiri et al., } \\
2015\end{array}$ \\
\hline $\begin{array}{l}\text { Multiple } \\
\text { Countries }^{\mathrm{c}}\end{array}$ & $\mathrm{BacH}$ & 61 & $77 \%$ & 1 to $1.0 \mathrm{E}+07$ copies/reaction & $\begin{array}{l}\text { Reischer et al., } \\
2013\end{array}$ \\
\hline USA & $\mathrm{BacH}$ & 4 & $100 \%$ & NR & $\begin{array}{l}\text { Layton et al., } \\
2013\end{array}$ \\
\hline $\begin{array}{l}\text { Multiple } \\
\text { Countries }^{d}\end{array}$ & BacHum-UCD & 61 & $87 \%$ & $\begin{array}{c}1 \text { to } 6.0 \mathrm{E}+06 \\
\text { gene copies/reaction }\end{array}$ & $\begin{array}{l}\text { Reischer et al., } \\
2013\end{array}$ \\
\hline India & BacHum-UCD & 30 & $40 \%$ & $\begin{array}{c}288\left( \pm 1.61 \log _{10}\right) \text { gene copies/ng } \\
\text { of total DNA }\end{array}$ & $\begin{array}{l}\text { Odagiri et al., } \\
2015\end{array}$ \\
\hline USA & BacHum-UCD & 24 & $100 \%$ & NR & $\begin{array}{l}\text { Layton et al., } \\
2013\end{array}$ \\
\hline USA & BacHum-UCD & 8 & $100 \%$ & $\begin{array}{l}6.4 \mathrm{E}+04 \text { to } 5.1 \mathrm{E}+08 \\
\text { gene copies/g }\end{array}$ & $\begin{array}{l}\text { Van De } \\
\text { Werfhorst et } \\
\text { al., } 2011\end{array}$ \\
\hline USA & BacHum-UCD & 18 & $66.7 \%$ & NR & $\begin{array}{l}\text { Kildare et al., } \\
2007\end{array}$ \\
\hline
\end{tabular}




\begin{tabular}{|c|c|c|c|c|c|}
\hline Area & Common Target Name & $\begin{array}{c}\text { Number of } \\
\text { samples }\end{array}$ & Sensitivity $^{a}$ & $\begin{array}{c}\text { Gene Copy Concentration } \\
\text { (Mean or Range) }\end{array}$ & Reference \\
\hline India & HumM2 & 30 & $40 \%$ & $\begin{array}{l}37\left( \pm 0.67 \log _{10}\right) \\
\text { gene copies/ng } \\
\text { of total DNA }\end{array}$ & $\begin{array}{c}\text { Van De } \\
\text { Werfhorst et } \\
\text { al., } 2011\end{array}$ \\
\hline USA & HumM2 & 24 & $100 \%$ & NR & $\begin{array}{l}\text { Layton et al., } \\
2013\end{array}$ \\
\hline USA & HumM2 & 16 & $100 \%$ & NR & $\begin{array}{l}\text { Shanks et al., } \\
\quad 2009\end{array}$ \\
\hline USA & HumM2 & 16 & $100 \%$ & $\begin{array}{c}2.6 \mathrm{E}+03\left( \pm 0.05 \log _{10}\right) \text { gene } \\
\text { copies/ng } \\
\text { of total DNA }\end{array}$ & $\begin{array}{l}\text { Shanks et al., } \\
2010\end{array}$ \\
\hline USA & 1,6-alpha mannanase & 4 & $100 \%$ & NR & $\begin{array}{l}\text { Layton et al., } \\
2013\end{array}$ \\
\hline USA & 1,6-alpha mannanase & 10 & $100 \%$ & $\begin{array}{c}6.88 \mathrm{E}+02 \text { to } 1.07 \mathrm{E}+09 \text { gene } \\
\text { copies/g }\end{array}$ & $\begin{array}{l}\text { Yampara-Iquise } \\
\text { et al., } 2008\end{array}$ \\
\hline USA & nifH & 20 & $95 \%$ & NR & $\begin{array}{l}\text { Layton et al., } \\
2013\end{array}$ \\
\hline France & B.adolescentis & 10 & $90 \%$ & $\begin{array}{c}5 \mathrm{E}+05 \text { to } 1.0 \mathrm{E}+09 \\
\text { gene copies/g }\end{array}$ & $\begin{array}{l}\text { Gourmelon et } \\
\text { al., } 2010\end{array}$ \\
\hline \multicolumn{6}{|c|}{ End-point ${ }^{\mathrm{e}}$} \\
\hline Canada & HF183 & 54 & $94 \%$ & NR & $\begin{array}{l}\text { Fremaux et al., } \\
2009\end{array}$ \\
\hline France & HF183 & 44 & $97.7 \%$ & NR & $\begin{array}{l}\text { Gourmelon et } \\
\text { al., } 2007\end{array}$ \\
\hline USA & HF183 & 13 & $84 \%$ & NR & $\begin{array}{l}\text { Bernhard and } \\
\text { Field, } 2000\end{array}$ \\
\hline USA & HF183 & 28 & $96 \%$ & NR & $\begin{array}{l}\text { Layton et al., } \\
2013\end{array}$ \\
\hline USA & HF183 & 16 & 37.5 & NR & $\begin{array}{l}\text { Shanks et al., } \\
2010\end{array}$ \\
\hline USA & nifH & 70 & $29 \%$ & NR & $\begin{array}{l}\text { Ufnar et al., } \\
\quad 2006\end{array}$ \\
\hline USA & esp & 12 & $83.3 \%$ & NR & $\begin{array}{c}\text { Layton et al., } \\
2009\end{array}$ \\
\hline
\end{tabular}

${ }^{\text {a }}$ Sensitivity is routinely expressed as the following: sensitivity $=\mathrm{TPC} /(\mathrm{TBC}+\mathrm{TNI})$, where TPC represents the total number of samples that tested positive correctly and TNI denotes the total number of samples that tested incorrectly. Specificity is typically defined as the total number of samples that test negative correctly (TNC) divided by the sum of TNC and the total number of samples that tested positive incorrectly (TPI) or TNC/(TNC+TPI);

${ }^{b}$ NR: Not reported; 'Argentina, Austria, Ethiopia, Germany,Hungary, Hungary, Korea, Nepal, Netherlands, Romania, Spain, Sweden, Tanzania ,Uganda, UK; 'Austria, Argentina, Australia, Ethiopia, Germany, Hungary, Korea, Nepal, Netherlands, Romania, Spain, Sweden, Tanzania, Uganda, UK, USA; ${ }^{\circ}$ endpoint is a non-quantitative method 
Table 9. Summary of human-associated MST method target occurrence in on-site* pollution sources in USA

\begin{tabular}{|c|c|c|c|c|}
\hline $\begin{array}{c}\text { Common } \\
\text { Target } \\
\text { Name }\end{array}$ & Number of Samples & Sensitivity $^{a}$ & Gene Copy Concentration (Mean or Range) & Reference \\
\hline \multicolumn{5}{|c|}{ SYBR } \\
\hline HF183 & 16 & 94 to $100 \%$ & $\mathrm{NR}^{\mathrm{b}}$ & $\begin{array}{l}\text { Layton et } \\
\text { al., } 2013\end{array}$ \\
\hline HF183 & 3 & $66.6 \%$ & $\begin{array}{l}9.8 \mathrm{E}+08 \text { to } 4.9 \mathrm{E}+09 \\
\text { gene copies/100mL }\end{array}$ & $\begin{array}{l}\text { Van De } \\
\text { Werfhorst } \\
\text { et al., } \\
2011\end{array}$ \\
\hline \multicolumn{5}{|c|}{ Taqman } \\
\hline HF183 & 20 & $100 \%$ & NR & $\begin{array}{l}\text { Layton et } \\
\text { al., } 2013\end{array}$ \\
\hline $\mathrm{BacH}$ & 4 & 75 to $100 \%$ & NR & $\begin{array}{l}\text { Layton et } \\
\text { al., } 2013\end{array}$ \\
\hline BacHum-UCD & 24 & $100 \%$ & NR & $\begin{array}{l}\text { Layton et } \\
\text { al., } 2013\end{array}$ \\
\hline BacHum-UCD & 3 & $100 \%$ & $\begin{array}{c}4.2 \mathrm{E}+05 \text { to } 6.5 \mathrm{E}+09 \\
\text { gene copies/100mL }\end{array}$ & $\begin{array}{l}\text { Van De } \\
\text { Werfhorst } \\
\text { et al., } \\
2011\end{array}$ \\
\hline HumM2 & 24 & 54 to $96 \%$ & NR & $\begin{array}{l}\text { Layton et } \\
\text { al., } 2013\end{array}$ \\
\hline $\begin{array}{l}\text { 1,6-alpha } \\
\text { mannanase }\end{array}$ & 4 & $100 \%$ & NR & $\begin{array}{l}\text { Layton et } \\
\text { al., } 2013\end{array}$ \\
\hline nifH & 20 & 65 to $85 \%$ & NR & $\begin{array}{l}\text { Layton et } \\
\text { al., } 2013\end{array}$ \\
\hline \multicolumn{5}{|c|}{ End-point } \\
\hline HF183 & 28 & $71 \%$ & NR & $\begin{array}{l}\text { Layton et } \\
\text { al., } 2013\end{array}$ \\
\hline HF183 & 16 & $100 \%$ & NR & $\begin{array}{l}\text { McQuaig } \\
\text { et al., } \\
2009\end{array}$ \\
\hline HF183 & 80 & $100 \%$ & NR & $\begin{array}{l}\text { Harwood } \\
\text { et al., } \\
2009\end{array}$ \\
\hline nifH & 16 & $93.7 \%$ & NR & $\begin{array}{l}\text { McQuaig } \\
\text { et al., } \\
2009\end{array}$ \\
\hline nifH & 25 & $100 \%$ & NR & $\begin{array}{l}\text { Harwood } \\
\text { et al., } \\
2009\end{array}$ \\
\hline $\begin{array}{l}\text { E. faecium } \\
\text { esp }\end{array}$ & 10 & $80 \%$ & NR & $\begin{array}{l}\text { Scott et } \\
\text { al., } 2005\end{array}$ \\
\hline $\begin{array}{l}\text { E. faecium } \\
\text { esp }\end{array}$ & 6 & $100 \%$ & NR & $\begin{array}{l}\text { Masago et } \\
\text { al., } 2011\end{array}$ \\
\hline
\end{tabular}

${ }^{a}$ Sensitivity is routinely expressed as the following: sensitivity $=\mathrm{TPC} /(\mathrm{TBC}+\mathrm{TNI})$, where TPC represents the total number of samples that tested positive correctly and TNI denotes the total number of samples that tested incorrectly. Specificity is typically defined as the total number of samples that test negative correctly (TNC) divided by the sum of TNC and the total number of samples that tested positive incorrectly (TPI) or TNC/(TNC+TPI);

${ }^{\mathrm{b}}$ NR: Not reported. In Australia, HF183 also found in 100\% of sewage samples $(\mathrm{n}=12)$ by end point chemistry (Ahmed et al., 2008) 
Table 10. Summary of reported non-human-associated MST gene target occurrence in Ruminant faecal and agricultural pollution sources ${ }^{\mathrm{a}}$

\begin{tabular}{|c|c|c|c|c|c|}
\hline Area & $\begin{array}{c}\text { Common Target } \\
\text { Name }\end{array}$ & $\begin{array}{c}\text { Number of } \\
\text { Samples } \\
\end{array}$ & Sensitivity $^{b}$ & $\begin{array}{c}\text { Gene Copy Concentration } \\
\text { (Mean or Range) } \\
\end{array}$ & Reference \\
\hline \multicolumn{6}{|c|}{ Taqman } \\
\hline Austria & BacR & 57 & $100 \%$ & $\begin{array}{c}4.10 \mathrm{E}+09 \\
\text { gene copies/g } \\
\text { wet faeces }\end{array}$ & $\begin{array}{l}\text { Reischer } \\
\text { et al., } \\
2006\end{array}$ \\
\hline $\begin{array}{l}\text { Multiple } \\
\text { Countries }^{c}\end{array}$ & BacR & 79 & $90 \%$ & $\begin{array}{l}0 \text { to } 1.0 \mathrm{E}+07 \\
\text { gene copies/reaction }\end{array}$ & $\begin{array}{l}\text { Reischer } \\
\text { et al., } \\
2013\end{array}$ \\
\hline Canada & BacR & 26 & $94.4 \%$ & $\begin{array}{l}1.94 \mathrm{E}+08 \\
\text { gene copies/g }\end{array}$ & $\begin{array}{l}\text { Ridley et } \\
\text { al., } 2014\end{array}$ \\
\hline France & BacR & 20 & $100 \%$ & $\begin{array}{c}1.0 \mathrm{E}+10\left( \pm 0.30 \log _{10}\right) \text { gene copies/g } \\
\text { of wet faeces }\end{array}$ & $\begin{array}{l}\text { Mieszkin } \\
\text { et al., } \\
2009\end{array}$ \\
\hline Israel & BacR & NR & $100 \%$ & $\mathrm{NR}^{\mathrm{d}}$ & $\begin{array}{l}\text { Ohad et } \\
\text { al., } 2015\end{array}$ \\
\hline USA & BacR & NR & $100 \%$ & $\begin{array}{c}1.48 \mathrm{E}+06 \text { to } \\
4.37 \mathrm{E}+07 \\
\text { gene copies/group }\end{array}$ & $\begin{array}{l}\text { Raith et } \\
\text { al., } 2013\end{array}$ \\
\hline Canada & CowM2 & 18 & $88.9 \%$ & $\begin{array}{l}1.44 \mathrm{E}+06 \\
\text { gene copies/g }\end{array}$ & $\begin{array}{l}\text { Ridley et } \\
\text { al., } 2014\end{array}$ \\
\hline India & CowM2 & 10 & $50 \%$ & $\begin{array}{c}10 \text { to } 158 \\
\text { gene copies/ng } \\
\text { of total DNA }\end{array}$ & $\begin{array}{l}\text { Odagiri et } \\
\text { al., } 2015\end{array}$ \\
\hline Israel & CowM2 & NR & $50 \%$ & NR & $\begin{array}{l}\text { Ohad et } \\
\text { al., } 2015\end{array}$ \\
\hline USA & CowM2 & 60 & $100 \%$ & NR & $\begin{array}{l}\text { Shanks et } \\
\text { al., } 2008\end{array}$ \\
\hline USA & CowM2 & Not known & $100 \%$ & $\begin{array}{l}6.31 \mathrm{E}+04 \text { to } 3.02 \mathrm{E}+05 \\
\text { gene copies/group }\end{array}$ & $\begin{array}{l}\text { Raith et } \\
\text { al., } 2013\end{array}$ \\
\hline Australia & CowM3 & 20 & $80 \%$ & NR & $\begin{array}{l}\text { Ahmed et } \\
\text { al., } 2013\end{array}$ \\
\hline Australia & CowM3 & 20 & $100 \%^{\mathrm{a}}$ & NR & $\begin{array}{l}\text { Ahmed et } \\
\text { al., } 2013\end{array}$ \\
\hline Israel & CowM3 & NR & $93 \%$ & NR & $\begin{array}{l}\text { Ohad et } \\
\text { al., } 2015\end{array}$ \\
\hline USA & CowM3 & 60 & $98 \%$ & NR & $\begin{array}{l}\text { Shanks et } \\
\text { al., } 2008\end{array}$ \\
\hline USA & CowM3 & Not known & $100 \%$ & $\begin{array}{l}3.3 \mathrm{E}+04 \text { to } 7.76 \mathrm{E}+05 \\
\text { gene copies/group }\end{array}$ & $\begin{array}{l}\text { Raith et } \\
\text { al., } 2013\end{array}$ \\
\hline France & Rum2Bac & 20 & $97 \%$ & $\begin{array}{c}1.6 \mathrm{E}+08 \\
\left( \pm 0.50 \log _{10}\right) \\
\text { to } 2.5 \mathrm{E}+08 \\
\left( \pm 0.13 \log _{10}\right) \\
\text { gene copies/g }\end{array}$ & $\begin{array}{l}\text { Mieszkin } \\
\text { et al., } \\
2010\end{array}$ \\
\hline France & Rum2Bac & 10 & $90 \%^{\mathrm{a}}$ & $\begin{array}{c}1.0 \mathrm{E}+07 \\
\left( \pm 0.05 \log _{10}\right) \\
\text { gene copies/g }\end{array}$ & $\begin{array}{l}\text { Mieszkin } \\
\text { et al., } \\
2010\end{array}$ \\
\hline USA & Rum2Bac & NR & $100 \%$ & 2.24 E+05 copies/group & $\begin{array}{l}\text { Raith et } \\
\text { al., } 2013\end{array}$ \\
\hline \multicolumn{6}{|c|}{ End-point $^{\mathrm{e}}$} \\
\hline France & CF193 & 44 & $95.4 \%$ & NR & $\begin{array}{c}\text { Gourmelon } \\
\text { et al., } \\
2007\end{array}$ \\
\hline Spain & CF193 & 19 & $0 \%$ & NR & $\begin{array}{c}\text { Balleste et } \\
\text { al., } 2010\end{array}$ \\
\hline USA & CF193 & 6 & $100 \%$ & NR & $\begin{array}{c}\text { Bernhard } \\
\text { and Field, } \\
2000\end{array}$ \\
\hline
\end{tabular}




\begin{tabular}{|c|c|c|c|c|c|}
\hline Area & $\begin{array}{c}\text { Common Target } \\
\text { Name }\end{array}$ & $\begin{array}{l}\text { Number of } \\
\text { Samples }\end{array}$ & Sensitivity $^{\mathrm{b}}$ & $\begin{array}{l}\text { Gene Copy Concentration } \\
\text { (Mean or Range) }\end{array}$ & Reference \\
\hline USA & CF193 & 247 from 11 herds & $68 \%$ & NR & $\begin{array}{l}\text { Shanks et } \\
\text { al., } 2010\end{array}$ \\
\hline USA & CF193 & NR & $67 \%$ & NR & $\begin{array}{l}\text { Raith et } \\
\text { al., } 2013\end{array}$ \\
\hline USA & CowM2 & 184 & $80 \%$ & NR & $\begin{array}{l}\text { Shanks et } \\
\text { al., } 2006\end{array}$ \\
\hline USA & CowM2 & 247 from 11 herds & 0 to $100 \%$ & NR & $\begin{array}{l}\text { Shanks et } \\
\text { al., } 2010\end{array}$ \\
\hline USA & CowM3 & 148 & $91 \%$ & NR & $\begin{array}{l}\text { Shanks et } \\
\text { al., } 2006\end{array}$ \\
\hline USA & CowM3 & 247 from 11 herds & 0 to $100 \%$ & $\begin{array}{l}10 \text { gene copies/ng } \\
\text { of total DNA }\end{array}$ & $\begin{array}{l}\text { Shanks et } \\
\text { al., } 2010\end{array}$ \\
\hline
\end{tabular}

${ }^{\text {a}}$ Represents any agricultural waste management practice such as lagoons, litter, etc.; ${ }^{\text {b}}$ Sensitivity is routinely expressed as the following: sensitivity $=\mathrm{TPC} /(\mathrm{TBC}+\mathrm{TNI})$, where TPC represents the total number of samples that tested positive correctly and TNI denotes the total number of samples that tested incorrectly. Specificity is typically defined as the total number of samples that test negative correctly (TNC) divided by the sum of TNC and the total number of samples that tested positive incorrectly (TPI) or TNC/(TNC+TPI); ${ }^{\circ}$ Austria, Argentina, Australia, Ethiopia, Germany, Hungary, Korea, Nepal, Netherlands, Romania, Spain, Sweden, Tanzania, Uganda, UK; ${ }^{d}$ NR: Not reported; ${ }^{e}$ endpoint is a non-quantitative method

Table 11. Summary of reported non-human-associated MST gene target occurrence in Porcine faecal and agricultural pollution sources $^{a}$

\begin{tabular}{|c|c|c|c|c|c|}
\hline Area & $\begin{array}{c}\text { Common } \\
\text { Gene Name }\end{array}$ & Number of Samples & Sensitivity $^{b}$ & $\begin{array}{c}\text { Gene Copy Concentration (Mean or } \\
\text { Range) }\end{array}$ & Reference \\
\hline \multicolumn{6}{|c|}{ Taqman } \\
\hline France & Pig2Bac & 25 & $100 \%$ & $\begin{array}{c}3.16 \mathrm{E}+08 \\
\left( \pm 0.60 \log _{10}\right) \\
\text { gene copies/g } \\
\text { wet faeces }\end{array}$ & $\begin{array}{l}\text { Mieszkin et al., } \\
2009\end{array}$ \\
\hline France & Pig2Bac & 53 & $100 \%^{\mathrm{a}}$ & $\begin{array}{c}3.98 \mathrm{E}+02 \\
\left( \pm 0.40 \log _{10}\right) \text { to } \\
1.99 \mathrm{E}+05 \\
\left( \pm 0.60 \log _{10}\right) \\
\text { gene copies/g }\end{array}$ & $\begin{array}{l}\text { Mieszkin et al., } \\
2009\end{array}$ \\
\hline Israel & Pig2Bac & $\mathrm{NR}^{\mathrm{c}}$ & $100 \%$ & NR & Ohad et al., 2015 \\
\hline USA & Pig2Bac & 20 & $100 \%$ & NR & $\begin{array}{c}\text { Boehm et al., } \\
2013\end{array}$ \\
\hline \multicolumn{6}{|c|}{ End-point $^{d}$} \\
\hline France & PF163 & 25 & $100 \%$ & NR & $\begin{array}{l}\text { Gourmelon et al., } \\
2007\end{array}$ \\
\hline France & PF163 & 10 & $100 \%$ & NR & $\begin{array}{l}\text { Gourmelon et al., } \\
2007\end{array}$ \\
\hline USA & PF163 & 30 & $100 \%$ & NR & $\begin{array}{l}\text { Toledo-Hernandez } \\
\quad \text { et al., } 2013\end{array}$ \\
\hline USA & PF163 & 2 & $100 \%$ & NR & Dick et al., 2005 \\
\hline USA & PF163 & 97 & $89.3 \%$ & NR & $\begin{array}{c}\text { Lamendella et al., } \\
2009\end{array}$ \\
\hline
\end{tabular}




\begin{tabular}{|c|c|c|c|c|c|}
\hline Area & $\begin{array}{l}\text { Common } \\
\text { Gene Name }\end{array}$ & Number of Samples & Sensitivity $^{b}$ & $\begin{array}{c}\text { Gene Copy Concentration (Mean or } \\
\text { Range) }\end{array}$ & Reference \\
\hline USA & PF163 & 6 & $100 \%^{\mathrm{a}}$ & NR & $\begin{array}{c}\text { Lamendella et al., } \\
2009\end{array}$ \\
\hline USA & PF163 & 50 & $100 \%$ & NR & $\begin{array}{l}\text { Fremaux et al., } \\
2009\end{array}$ \\
\hline
\end{tabular}

${ }^{a}$ Represents any agricultural waste management practice such as lagoons, litter, etc.; ${ }^{b}$ Sensitivity is routinely expressed as the following: sensitivity $=\mathrm{TPC} /(\mathrm{TBC}+\mathrm{TNI})$, where TPC represents the total number of samples that tested positive correctly and TNI denotes the total number of samples that tested incorrectly. Specificity is typically defined as the total number of samples that test negative correctly (TNC) divided by the sum of TNC and the total number of samples that tested positive incorrectly (TPI) or TNC/(TNC+TPI); ${ }^{\mathrm{N} R}$ : Not reported; ${ }^{\mathrm{d}}$ endpoint is a non-quantitative method

Table 12. Summary of reported non-human-associated MST gene target occurrence in Avian faecal and agricultural pollution sources ${ }^{\mathrm{a}}$

\begin{tabular}{|c|c|c|c|c|c|}
\hline Area & $\begin{array}{c}\text { Common } \\
\text { Target } \\
\text { Name } \\
\end{array}$ & $\begin{array}{l}\text { Number of } \\
\text { Samples }\end{array}$ & Sensitivity ${ }^{b}$ & Gene Copy Concentration (Mean or Range) & Reference \\
\hline \multicolumn{6}{|c|}{ SYBR } \\
\hline Australia & GFD & 36 & $58 \%$ & $\begin{array}{c}1.9 \text { to } 7.20 \mathrm{E}+03 \text { gene copies/ng } \\
\text { of total DNA }\end{array}$ & $\begin{array}{l}\text { Ahmed et } \\
\text { al., } 2016\end{array}$ \\
\hline USA & GFD & 10 & $30 \%$ & $\begin{array}{c}1.10 \mathrm{E}+01 \text { to } \\
6.4 \mathrm{E}+03 \\
\text { gene copies/ng } \\
\text { of total DNA }\end{array}$ & $\begin{array}{l}\text { Ahmed et } \\
\text { al., } 2016\end{array}$ \\
\hline USA & LA35 & 26 & $54 \%$ & $\begin{array}{c}2.80 \mathrm{E}+04 \\
\text { gene copies/g }\end{array}$ & $\begin{array}{l}\text { Weidhaas } \\
\text { et al., } \\
2010\end{array}$ \\
\hline USA & LA35 & 17 & $100 \%^{\mathrm{a}}$ & $\begin{array}{c}1.5 \mathrm{E}+07 \text { to } \\
3.70 \mathrm{E}+09 \\
\text { gene copies/g }\end{array}$ & $\begin{array}{l}\text { Weidhaas } \\
\text { et al., } \\
2010\end{array}$ \\
\hline USA & LA35 & 186 & $22.6 \%$ & $\begin{array}{l}3.12 \mathrm{E}+03 \\
\text { gene copies/g }\end{array}$ & $\begin{array}{l}\text { Ryu et al., } \\
2014\end{array}$ \\
\hline USA & LA35 & 40 & $97.5 \%^{\mathrm{a}}$ & $\begin{array}{c}1.0 \mathrm{E}+07 \\
\text { gene copies/g }\end{array}$ & $\begin{array}{l}\text { Ryu et al., } \\
2014\end{array}$ \\
\hline \multicolumn{6}{|c|}{ End-point } \\
\hline USA & Gull4 & 255 & $86.7 \%$ & $\begin{array}{c}\text { E+05 copies/ng } \\
\text { of total DNA }\end{array}$ & $\begin{array}{l}\text { Ryu et al., } \\
2012\end{array}$ \\
\hline
\end{tabular}

${ }^{a}$ Represents any agricultural waste management practice such as lagoons, litter, etc.; ${ }^{b}$ Sensitivity is routinely expressed as the following: sensitivity $=\mathrm{TPC} /(\mathrm{TBC}+\mathrm{TNI})$, where TPC represents the total number of samples that tested positive correctly and TNI denotes the total number of samples that tested incorrectly. Specificity is typically defined as the total number of samples that test negative correctly (TNC) divided by the sum of TNC and the total number of samples that tested positive incorrectly (TPI) or TNC/(TNC+TPI).

3.2.2 Occurrence of host-associated MST genetic markers in non-target pollution sources

It is important to characterize the potential for falsepositives when interpreting MST findings. False positives typically result from the occurrence of a host-associated genetic marker in a non-target pollution source. For example, a human-associated MST genetic marker could also be present in chicken waste leading to reduced confidence in human faecal pollution characterization. This 
could be problematic if the study area of interest is impacted by both human and chicken faecal pollution sources. As a result, a considerable amount of research has been conducted to characterize the occurrence of MST genetic markers in non-target faecal waste sources (Table 10). Specificity is the most common performance metric reported for PCR-based applications. In addition, the concentration of a host-associated genetic marker (gene copies/volume, mass, or cell count) in a non-target source is often reported for qPCR methodologies. Just like sensitivity testing (Section 3.2.1), it is important to consider the limit of detection definition, test quantity used, and any differences in methodology from one study to another when evaluating specificity findings. Table 10 summarizes available MST genetic marker occurrence data in nontarget sources by methodology and geographic origin of reference waste samples. Even though there is a considerable amount of information available on the occurrence of MST genetic markers in non-target pollution sources, it is highly recommended that local reference pollution samples are tested in the area of interest prior to method implementation to confirm specificity performance. For more detailed information, please refer to Appendix A. 4.0

\subsection{Persistence of Faecal Indicator Bacteria (FIB)}

Assessing the persistence of FIB in aquatic environments is complicated by the potential for waste inputs from multiple sources at any given time in a study, therefore persistence is generally measured in experiments where FIB are contained, as in laboratory glassware (Wanjugi and Harwood, 2014; Korajkic et al., 2013) or dialysis bags (Korajkic et al., 2013; Korajkic et al., 2014). Persistence studies can be very valuable for the selection of appropriate FIB for a particular application. For instance Bifidobacterium spp. have limited persistence in the environment and are very sensitive to chlorination, which could make them a poor choice for FIB monitoring in chlorinated waters (Resnick and Levin, 1981). Persistence experiments have been conducted under varying conditions, using many different models to assess changes in density over time, and therefore frequently provide discrepant results, which can lead to varying conclusions about the survival of FIB in surface waters. In general, predation (Wanjugi and Harwood, 2014; Korajkic et al., 2013, 2014), competition from other bacteria (Wanjugi and Harwood, 2013; Surbeck et al., 2010) and ultraviolet radiation exposure (Nguyen et al., 2015; Sassoubre et al., 2012) have a negative impact on FIB persistence, while the presence of sediments (Badgley et al., 2010) and high nutrient levels (Wanjugi et al., 2016) often increase FIB survival times. An overview of select key studies are summarized below. Please refer to the Section IV on Persistence and Transport for additional information.

Jeanneau and colleagues (2012) evaluated the persistence of FIB in sewage-spiked seawater, and reported the highest $\mathrm{T}_{90}$ value ( \pm standard error) of $3.7 \pm 0.1$ days for a phylotype related to Bifidobacterium adolescentis (measured via qPCR), followed by $3.6 \pm 0.8$ days for culturable enterococci, $2.3 \pm 0.2$ days for the HF183 Bacteroides 16S rDNA marker; culturable E. coli had the lowest $T_{90}$ value of $1.7 \pm 0.1$ days in seawater (Jeanneau et al., 2012). In sewage-spiked freshwater, the same authors reported the highest $T_{90}$ value (longest persistence) for culturable E. coli (5.8 \pm 0.2 days), with lower values for enterococci (3.1 \pm 0.5 days) and qPCR-quantified $B$. adolescentis ( $3.6 \pm 0.2$ days), and the lowest $T_{90}$ value for the HF183 Bacteroides qPCR marker $(1.7 \pm 0.0$ days $)$ (Jeanneau et al., 2012). In freshwater mesocosms spiked with sewage and dog faeces, Anderson et al., (2005) reported faecal coliform decay rates of 0.27 to $0.37 \log _{10}$ (CFU/100mL) per day, respectively (Anderson et al., 2005). The reported faecal coliform decay rates in saltwater mesocosms spiked with sewage and dog faeces were 4.2 and $3.8 \log _{10}(\mathrm{CFU} / 100 \mathrm{~mL})$ per day, respectively. For enterococci relative to faecal coliforms, the same authors reported a greater decay rate in freshwater spiked with dog faeces, a similar decay rate in sewage-spiked freshwater, and a lower decay rate in sewage-spiked seawater. Decay rates in sediments were also reported to be lower than decay rates in the water column. These examples illustrate the difficulty of comparing studies that use different metrics to measure persistence, and that different bacterial species and DNA targets respond differently to environmental stressors, making generalizations about persistence very challenging.

In site studies of FIB persistence and transport in environmental habitats are possible when there is a clear connection between the infrastructure of interest and a waste stream. A systematic review of the FIB transport from pit latrines (infrastructure) to nearby groundwater sources has been reported; however, extrapolating transport distances to other locations can be challenging due poor characterization of flow rates, differences in soil types and groundwater conditions (Graham and Polizzotto, 2013). For example, the formation of a biologically active scum layer around the latrine pit can limit the movement of FIB from the pit area. Some studies have reported maximum transport distances of 10 meters (Banerjee et al., 2011), while others have reported transport up to 20 meters (Chidavaenzi et al., 2000). More information about the persistence of FIB in the environment and in sanitation technologies can be found in Chapters 15 and 16 .

\subsection{Overview of Persistence of Host-Associated Genetic Markers}

A brief overview of the persistence literature available pertaining to host-associated bacterial MST genetic markers, as well as the discussion of some important methodological considerations for interpreting decay data are presented here. For more detailed information regarding persistence of human-associated MST markers (e.g. $T_{90}$ times), please see chapters entitled "Using indicators to assess microbial treatment and disinfection efficacy" and "Evaluation of subsurface microbial transport using microbial indicators, surrogates and tracers." The majority of studies to date focus on investigating persistence of human-, ruminant-, and cow-associated indicators in aquatic habitats (Bae and Wuertz, 2009; Sokolova et al., 2012; Tambalo et al., 2012; Walters and Field, 2009). Some of the biotic and abiotic factors 
commonly investigated include ambient sunlight (Korajkic et al., 2014; Green et al., 2011), water type (freshwater, estuarine, or marine) (Jeanneau et al., 2012; Green et al., 2011; Ahmed et al., 2014), temperature (Dick et al., 2010; Kreader, 1998; Okabe and Shimazu, 2007), influence of indigenous microbiota, and faecal pollution source (Bae and Wuertz, 2009; Sokolova et al., 2012; Tambalo et al., 2012; Walters and Field, 2009). Comparisons across studies and derivation of any overarching conclusions with respect to the effect of these stressors is challenging as many studies report conflicting results. For example, ambient sunlight has been reported to be detrimental by some researchers, but not others (Korajkic et al., 2014; Walters and Field, 2009; Green et al., 2011; Dick et al., 2010; Savichtcheva et al., 2007). It has been suggested that the effect of sunlight on host-associated indicators is linked to the physiological state of the organisms (Bae and Wuertz, 2009), as well as the stage of the decomposition process (Korajkic et al., 2014). A majority of studies tend to agree that persistence is typically longer at colder temperatures compared to warmer conditions (Kreader, 1998; Silkie and Nelson, 2007) and in marine waters compared to freshwater (Jeanneau et al., 2012; Green et al., 2011; Okabe and Shimazu, 2007; Schulz and Childers, 2011).

The apparent discord in literature is likely due to the wide variety of experimental designs employed, as well as lack of method protocol standardization, use of different units of measure, and varied data modeling practices. One of the important methodological factors likely to influence the outcome of a persistence study is whether the experiments were performed indoors or outdoors as the latter mimics ambient conditions more closely compared to bench-scale laboratory experiment with artificial lighting (Korajkic et al., 2014; Jeanneau et al., 2012; Bae and Wuertz, 2009; Sokolova et al., 2012; Tambalo et al., 2012; Green et al., 2011; Ahmed et al., 2014; Dick et al., 2010; Kreader, 1998; Okabe and Shimazu, 2007; Savichtcheva et al., 2007; Schulz and Childers, 2011). Observed persistence patterns can also depend on the type and amount of faecal source(s) inoculated as these factors vary widely. For example, the seeded faecal pollution source can range from a single $E$. coli laboratory strain to a composite mixture, such as sewage or septage waste. As a result, generalizations across studies seeded with different pollution sources can be misleading. Due to the potential for bias and large discrepancies in faecal pollution decomposition from one locale to the next, it may be necessary to perform decay studies in the area of interest prior to water quality testing, if persistence data are needed to interpret host-associated indicator results.

\subsection{Applications and Future Directions}

There are many potential applications for FIB and hostassociated genetic MST methods. FIB are commonly used around the world in regulatory settings for sewage effluent discharge control, recreational and aquaculture water quality monitoring, as well as drinking water safety assessments (see Tables 2 and 3) for over a century (Hacker and Blum-Oehler, 2007; Escherich, 1885). It is likely that FIB will continue to be employed in the regulatory arena with an expanded utility in greywater safety testing and monitoring irrigation waters used for agricultural food production.

There are currently no formal regulatory applications or standardized methods for any MST technology. However, the United States Environmental Protection Agency is working towards the development of standardized procedures for two human-associated qPCR methods including HF183/BacR287 and HumM2. Data acceptance metrics are available for these technologies (Shanks et al., 2016) and they have performed well in two separate multiple laboratory validation studies (Shanks et al., 2016; Layton et al., 2013). As these MST methods transition from research approaches to management tools, future studies will focus on potential regulatory and water quality management strategies.

Finally, it is important to recognize the role that emerging technologies will play in future applications of FIB and MST methods. Emerging technologies refer to new methodologies with the potential to improve FIB and MST indicator characterization. Emerging applications will doubtlessly harness the power of high throughput nucleic acid sequencing and other methodologies for the rapid and simultaneous measurements of multiple bacterial indicators. These novel technologies coupled with QMRA will likely provide future water quality managers, public health officials, and researchers with powerful tools to predict human health risk from exposure to faecal pollution. 


\section{Appendix A. Occurrence of Host- Associated Genetic Markers in Target and Non-}

\section{Target Sources}

\section{A.1.0 Human-Associated Methods}

\section{A.1.1 Bacteroidales}

\section{A.1.1.1 HF183/708R End-Point PCR.}

For the HF183/708R end-point PCR method, initial specificity testing (10 non-human animal species; $\mathrm{n}=27$ individual samples) indicated $100 \%$ specificity while sensitivity ranged from $84 \%$ in human faecal samples $(n=13)$ to $100 \%$ in untreated sewage $(n=3)$ (Bernhard and Field, 2000). Sensitivity and specificity of the HF183/708R assay in the end-point format has been tested in various regions of the United States (Bernhard and Field, 2000; Toledo-Hernandez et al., 2013; McQuaig et al., 2009; Shanks et al., 2010; Layton et al., 2013; Harwood et al., 2009), as well as Australia (Ahmed et al., 2008), Spain (Balleste et al., 2010), Canada (Edge et al., 2013; Fremaux et al, 2009) and France (Gourmelon et al., 2007). A wide range of sensitivity and specificity was reported, depending on the region and the reference pollution sources tested. In addition to the developing laboratory, five reports originating from the United States described performance of the end-point HF183/708R assay. Shanks et al. tested sensitivity against human faecal samples collected from 16 individuals, as well as 54 wastewater effluents collected across the country (Shanks et al., 2010). HF183/708R marker was detected in all 54 wastewater samples $(100 \%$ sensitivity) and six (out of 16) individual human faecal samples (Shanks et al., 2010). Specificity was reported at $95 \%$, as it cross-reacted with one (out of 10) dog samples, but not with other faecal samples collected from 21 nontarget animal species (Shanks et al., 2010). A study conducted in Puerto Rico tested the end-point assay against 16 wastewater samples and 340 individual animal faecal samples collected from 12 non-target species eliciting a $75 \%$ sensitivity and $100 \%$ specificity as it was not detected in any of the non-target hosts (Toledo-Hernandez et al., 2013). Three hundred twenty-two non-target waste samples ranging from individual faecal samples to large-scale composites from Florida and Mississippi were tested to determine specificity of the HF183/708R end-point assay (Harwood et al., 2009). False-positives were detected in samples originating from dog, chicken and seagull for an overall reported specificity of 96\% (Harwood et al., 2009). The same study also determined the assay to be $100 \%$ sensitive when tested against wastewater samples $(n=48)$ and various on-site collection systems (e.g. lift stations, sewage lagoons and septic systems, $n=80$ ) (Harwood et al., 2009). Another Florida-based study performed specificity testing against individual faecal samples from 13 non-target animal sources $(n=113)$ and 2 composite farm animal sources (McQuaig et al., 2009). The HF183/708R marker was found to cross-react with $13 \%$ of non-target samples, including one cat sample (out of five) and 14 (out of 55) dog samples (McQuaig et al., 2009). In the same study, sensitivity of the assay was determined to be $100 \%$ when tested against 39 wastewater samples and 16 on-site collection systems (McQuaig et al., 2009). As a part of the comprehensive method comparison study conducted in California and involving 27 laboratories worldwide, HF183/708R end-point assay was tested against human faecal samples, septage samples, wastewater samples, as well as composite faecal samples from nine non-target hosts (McQuaig et al., 2009). Sensitivity to human faecal sources ranged from $57 \%$ (sewage), to $71 \%$ (septage) to human faeces (96\%), while the reported specificity was 96\% (McQuaig et al., 2009). The performance of the HF183/708R end-point assay was also tested in Australia against 12 non-target animal species (total of 155 faecal samples), as well as 52 human samples, including primary wastewater effluent $(n=15)$, secondary effluent $(n=15)$, treated effluent $(n=15)$ and 12 septic system samples (Ahmed et al., 2008). The HF183/708R marker was detected in all human samples and none of the non-target samples with a reported sensitivity and specificity of $100 \%$ (Ahmed et al., 2008). The sensitivity and specificity of HF183/708R end-point assay were considerably lower when tested in Spain (Balleste et al., 2010). Marker was challenged by testing it against wastewater, as well as effluents from poultry slaughterhouses, swine faeces, slurry from slaughterhouses and a farm, ruminant slaughterhouses and bovine farms. Reported sensitivity was $50 \%$ as it was detected in only 20 wastewater samples (out of 40 ), while specificity was higher (71\%) with crossreactions observed with cow (3 out of 19), poultry (15 out of 26) and swine (3 out of 28) (Balleste et al., 2010). In Canada, HF183/708R end-point assay was tested against 102 final wastewater effluents and it was detected in $74 \%$ of samples (Edge et al., 2013). Marker was also tested against faecal samples from eight non-target hosts and detected in one (out of 17) dog sample and one (out of 15) chicken sample, but it was not detected in cat, gull, Canada geese, mallard duck, cow and pig (total of 207) samples (Edge et al., 2013). Another Canada based study tested the HF183/708R marker against 62 individual human and wastewater samples, as well as 211 samples from 11 nontarget animal groups (Fremaux et al., 2009). The HF183/708R marker was detected in 94\% (51 out of 54) individual human samples, $100 \%$ (8 out of 8) wastewater samples and it exhibited 100\% specificity (Fremaux et al., 2009). In France, end-point HF183/708R assay was challenged against individual human faecal samples $(\mathrm{n}=44)$, as well as wastewater $(\mathrm{n}=5)$ and sludge samples $(n=6)$ (Gourmelon et al., 2010). Marker was detected in 43 individual human samples and all of the wastewater samples. Specificity was assessed by testing the marker against pig, cow, sheep, chicken and wildbirds, as well as pig manure. The HF183/708R marker was absent from pig (individual samples and manure), sheep and wildbird samples, but was detected in four (out of 32) cow samples and one (out of 10) chicken sample (Gourmelon et al., 2010).

A.1.1.2 HF183/708R SYBR Green Chemistry qPCR method. 
Several years later, the end-point PCR HF183/708R method was adapted to a SYBR Green qPCR chemistry with a reported sensitivity ranging from $85.7 \%$ in human faecal samples $(n=7)$ to $100 \%$ in sewage $(n=4)$ (Seurinck et al., 2005). The same study reported that the SYBR Green HF183/708R assay cross-reacted with one chicken faecal sample, but tested negative against four other non-target animal groups. In addition to the developer's laboratory (located in Belgium), sensitivity and specificity of the HF813/708R assay using SYBR green chemistry has also been tested in Australia (Ahmed et al., 2009; Ahmed et al., 2015), Bangladesh (Ahmed et al., 2010), India (Odagiri et al., 2015) and the United States (Layton et al., 2013; Van De Werfhorst et al., 2011). In Australia, the performance was assessed by testing the marker against 32 wastewater influent samples and individual faeces and composite wastewater samples from five non-target groups including cattle, sheep, pigs, dogs and ducks (Ahmed et al., 2009). The HF183/708R SYBR green marker was found to be $100 \%$ sensitive and $98 \%$ specific as it was detected in all human samples and one dog faecal sample (Ahmed et al., 2009). A subsequent study conducted in three different climatic zones in Australia equivalent to subtropical, Mediterranean, and temperate conditions provided additional sensitivity data for the SYBR green HF183 assay (Ahmed et al., 2015). In this study, a total of 99 wastewater influent samples from three wastewater treatment plants located in the above described climatic zones was collected. The HF183/708R SYBR green marker was detected in all of the wastewater samples with a reported mean concentration of $8.0 \times 10^{5}$ gene copies $/ \mathrm{mL}$ (Ahmed et al., 2015). A study conducted in Bangladesh tested the HF183/708R SYBR green assay against 45 faecal samples from humans, cattle, dogs, cats and chickens (Ahmed et al., 2010). Overall sensitivity was $87 \%$, as it was detected in 13 (out of 15) human faecal samples (Ahmed et al., 2010). Specificity was 93\% as it was detected in 1 dog and 1 cat sample (Ahmed et al., 2010). Reported levels in target sources ranged from $1.2 \times 10^{6}$ to $3.9 \times 10^{8} / 100 \mathrm{mg}$ of faeces, while levels in dog and cat samples were $7.8 \times 10^{4}$ and $4.6 \times$ $10^{3}$, respectively (Ahmed et al., 2010). Another study from India tested the HF183/708R SYBR green marker on 60 composite samples comprised from cow $(n=50)$, buffalo $(n=50)$, sheep $(n=50)$, goat $(n=50)$, chicken $(n=96)$, dog $(\mathrm{n}=50)$, as well as 30 individual human samples, 5 sewage samples and 20 samples from patients with diarrhea (Odagiri et al., 2015). The HF183/708R SYBR green assay indicated a sensitivity of $89 \%$ as it was detected in 26 healthy human faecal samples and all 5 wastewater samples (but not in any samples of patients with diarrhea) (Odagiri et al., 2015). When DNQ data was considered negative, sensitivity of the HF183/708R SYBR green assay was $63 \%$ (Odagiri et al., 2015). Cross-reactivity was observed with $100 \%$ to cow, buffalo, goat, sheep, and chicken, as well as $80 \%$ with dog faecal samples (Odagiri et al., 2015). Specificity was reported at 3\% (DNQ considered positive) or $63 \%$ (DNQ considered negative) (Odagiri et al., 2015). Concentrations were reported as mean $\log _{10}$ gene copies per nanogram of total DNA in human faeces $(0.96 \pm 1.64)$ and sewage $(1.67 \pm 0.47)$, while reported levels in non-target samples were as follows: 1.63 (cow), $1.41 \pm 0.49$ (buffalo), $2.23 \pm 1.0$ (goat), $1.04 \pm 1.0$ (dog),
$3.09 \pm 1.11$ chicken, and no sheep samples were within range of quantification (Odagiri et al., 2015). Two California based studies tested the performance of SYBR green HF183 assay (Layton et al., 2013; Van De Werfhorst et al., 2011). The first study tested sensitivity and specificity against individual human faecal samples, septage, sewage and faeces from five non-target animal hosts including cat, dog, gull, raccoon and rat $(n=4)$ (Van De Werfhorst et al., 2011). The HF183/708R SYBR green marker was detected in 5 (out of 8 ) human faecal samples in concentrations ranging from $4.9 \times 10^{3}$ to $5.3 \times 10^{8}$ per gram (wet weight) (Van De Werfhorst et al., 2011). It was also present in 2 out of 3 septage samples in levels ranging from $9.8 \times 10^{7}$ to $4.9 \times 10^{8} / \mathrm{L}$ and in 10 out of 10 sewage samples ranging from $4 \times 10^{7}$ to $2.5 \times 10^{9} / \mathrm{L}$ (Van De Werfhorst et al., 2011). The HF183/708R SYBR green marker was also detected in 1 (out of 12) cat sample (2.6 x $10^{3} /$ gram, wet weight), but not in any other non-target samples (Van De Werfhorst et al., 2011). The same comprehensive method evaluation study described earlier for HF183/708R end-point assay also tested the performance of SYBR green and TaqMan chemistries (Layton et al., 2013). In this study, results from qPCR assays were reported under different conditions including classification of samples that were detectable but not quantifiable (DNQ) as positive or negative and by utilizing different reference units of measure (culturable indicator bacteria, wet mass, total DNA and qPCR for different general faecal indicators) (Layton et al., 2013). Sensitivity was determined for different types of human sources (faeces, septage or sewage), while specificity was tested against composite faecal samples from nine non-target hosts (Layton et al., 2013). When evaluated against 48 human faecal samples, sensitivity of the HF183/708R SYBR green assay was determined to be $100 \%$ or $92 \%$, when considering DNQ as positive or negative, respectively (Layton et al., 2013). Testing against 104 non-target samples resulted in specificities of $78 \%$ and $89 \%$ with DNQ classified as positive or negative, respectively (Layton et al., 2013). When different human sources were considered separately, sensitivity to all three types was $100 \%$ with DNQ considered positive, but it varied when DNQ was considered negative (81\% for sewage, $94 \%$ for septage and $100 \%$ for faeces) (Layton et al., 2013). Expressing the abundance in different units of measure (eg. Wet mass, total DNA, etc) resulted in a wide range of concentrations for both target and non-target sources. Median $\log _{10}$ marker concentrations in human fecal samples ranged from: $5.9 \pm 1.1$ per $\mathrm{mg}$ of wet weight, $1.7 \pm 1.5$ per nanogram of total DNA, $1.9 \pm 1.4$ per culturable enterococci (USEPA, 2006), - 0.9 \pm 1.5 per enterococci via Entero1a qPCR (Haugland et al., 2005), $0.5 \pm 1.3$ per culturable E. coli via membrane filtration, $-0.2 \pm 1.2$ per E. coli via EC23S857 qPCR (Chern et al., 2011), $-2.2 \pm 0.8$ per Bacteroidales via GenBac3 qPCR (Siefring et al., 2008), -2.1 \pm 0.3 per Bacteroidales via AllBac qPCR (Layton et al., 2006) and $-1.5 \pm 0.5$ per Bacteroides (Converse et al., 2009). Following the same order, median $\log _{10}$ concentrations in non-target hosts was as follows: $2.3 \pm 1,-0.2 \pm 0.8,-0.9 \pm 1.4,-3.7 \pm 1.3$, $-2.1 \pm 1.4,-3.2 \pm 1.3,-5.4 \pm 1.9$ and -5.1 (Layton et al., 2013). 
A.1.1.3 HF183/BFDrev TaqMan qPCR.

A TaqMan qPCR HF183/BFDrev qPCR method soon followed with a reported sensitivity of $100 \%$ in human faecal samples $\left(n=16 ; 3.17 \pm 0.07 \log _{10}\right.$ gene copies/ng of total DNA) and sewage samples $\left(\mathrm{n}=14\right.$; median $\sim 2.8 \log _{10}$ gene copies/ng of total DNA) (Haugland et al., 2010). The product of the TaqMan qPCR HF183/BFDrev assay was not detected in composite preparations of cattle, pig and cat faecal samples ( $n=10$ each animal source), but it did crossreact with composites of chicken faeces $(n=10 ; 0.35 \pm 0.07$ $\log _{10}$ gene copies/ng of total DNA) and dog faeces $(n=10$; $0.36 \pm 0.07 \log _{10}$ gene copies/ng of total DNA) (Haugland et al., 2010). The widespread use of HF183/BFDrev qPCR technology and performance in multiple validation studies (Harwood et al, 2009; Boehm et al., 2013; Griffith et al., 2003) led a team of MST scientists to develop an improved TaqMan qPCR method, HF183/BacR287 (Green et al., 2014). In head-to-head experiments (HF183/BFDrev versus HF183/BacR287), HF183/BacR287 was reported to exhibit increased precision and an improved limit of detection in sewage samples (Green et al., 2014). The same California based method comparison study is the also evaluated sensitivity and specificity metrics for HF183/BFDrev TaqMan other than the developing laboratory (Layton et al., 2013). Sensitivity ( $n=60$ samples) and specificity $(n=130$ samples) were determined to be $100 \%$ and $46 \%$ or $95 \%$ and $92 \%$ when DNQ samples were considered to be positive or negative, respectively (Layton et al., 2013). When considered by the animal source group, sensitivity was $100 \%$ across the board with DNQ deemed positive, but it ranged from $85 \%$ (sewage) to $100 \%$ (human faeces and septage) when DNQ was considered negative (Layton et al., 2013). Similar to HF183/708R SYBR green qPCR assay, abundance in target and non-target sources varied widely when expressed using different units of measure. The reported concentrations in target and non-target samples were: $\log _{10} 6.9 \pm 0.1 / 1.2 \pm 0.9$ copies per milligram of wet weight, $\log _{10} 2.2 \pm 1.5 /-0.5 \pm 0.8$ copies per nanogram of total DNA, $\log _{10} 2.4 \pm 1.1 /-1.1 \pm 1.5$ copies per culturable enterococci (USEPA, 2006), $\log _{10}-0.3 \pm 1.7 /-4 \pm 1.3$ copies per enterococci qPCR (Haugland et al., 2005), $\log _{10}$ $1.3 \pm 0.6 /-2.8 \pm 1.4$ copies per culturable E. coli (via membrane filtration), $\log _{10} 0.5 \pm 0.3 /-3.2 \pm 1.1$ copies per E.coli qPCR (Chern et al., 2011), and $\log _{10}$ $-1.7 \pm 0.6 /-5.1 \pm 2.1$ copies per GenBac3 qPCR (Siefring et al., 2008). A previously described study from India also evaluated sensitivity and specificity metrics of the HF183/BFDrev TaqMan assay (Odagiri et al., 2015). Regardless of whether DNQ samples were considered positive or negative, the assay had sensitivity of $29 \%$ as it was detected in $16.7 \%$ of healthy human faeces and $100 \%$ of sewage samples (assay was also detected in $40 \%$ of human samples with diarrhea) (Odagiri et al., 2015). Specificity was reported at $80 \%$, irrespective of the DNQ classification as it cross-reacted with $40 \%$ of dog samples and $80 \%$ of chicken samples (Odagiri et al., 2015). Mean $\log _{10}$ gene copies per nanogram of DNA in human samples was as follows: $2.31 \pm 1.71$ (faeces from healthy humans), $2.29 \pm 0.72$ (sewage) and $1.70 \pm 1.27$ (faeces from humans with diarrhea) (Odagiri et al., 2015). Levels in dog and chicken faeces were $1.49 \pm 1.12$ and $3.52 \pm 1.16$, respectively (Odagiri et al., 2015).

\section{A.1.1.4 BacH TaqMan qPCR.}

BacH is also a TaqMan qPCR assay that targets the $B$. doreii 16S rRNA gene cluster (Reischer et al., 2007). In the original report, $\mathrm{BacH}$ was absent in faeces from 15 nonhuman animal groups ( $\mathrm{n}=302$ individual samples) and only cross-reacted with a single cat faecal sample (Reischer et al., 2007). BacH sensitivity ranged from $95 \%$ in human faecal samples $\left(n=21 ; 6.6 \times 10^{9}-9.1 \times 10^{10}\right.$ marker equivalents/g wet faeces) to $100 \%$ in wastewater and cesspit samples $\left(\mathrm{n}=21 ; 1.4 \times 10^{10}-9.1 \times 10^{10}\right.$ marker equivalents/g) (Reischer et al., 2007). In addition to the developing laboratory located in Austria and a study conducted in India (Odagiri et al., 2015), performance metrics of BacH TaqMan assay have been evaluated in two other large method performance studies to date (Layton et al., 2013; Reischer et al., 2013), providing sensitivity and specificity data across sixteen countries including Argentina, Australia, Austria, Ethiopia, Germany, Hungary, India, Korea, Nepal, Netherlands, Romania, Spain, Sweden, Tanzania, Uganda, United Kingdom and United States. The United States based method evaluation study reported sensitivity ( $\mathrm{n}=12$ samples) and specificity ( $\mathrm{n}=26$ samples) as $100 \%$ and $77 \%$ and $75 \%$ and $85 \%$ when DNQ data were considered as positive or negative, respectively (Layton et al., 2013). Considering sensitivity in relation to the type of human source, the BacH qPCR assay was $100 \%$ sensitive when DNQ was considered positive, but it ranged from $50 \%$ (sewage) to $75 \%$ (septage) to $100 \%$ when DNQ was considered negative (Layton et al., 2013). The same study reported concentration of BacH qPCR marker in target and non-target samples using the above described different units of measure. Reported median $\log _{10}$ values for sensitivity and specificity were as follows: $7.5 \pm 0.2$ and $2.8 \pm 0.9 / \mathrm{mg}$ of wet weight, $1.9 \pm 2$ and $0.9 \pm 0.9 / \mathrm{ng}$ of total DNA, $2.1 \pm 1.8$ and $-1.5 \pm 1.8$ per culturable enterococci (USEPA, 2006), $1.5 \pm 0.9$ and $-1.5 \pm 1.2$ per culturable $E$. coli, $0.6 \pm 0.9$ and $-2.2 \pm 0.9$ per E. coli qPCR (Chern et al., 2011). A global method comparison study encompassing six continents tested sensitivity and specificity on 280 individual faecal samples from humans and variety of animals including ruminants (cattle, sheep, deer, goat, chamois and lama), non-ruminant herbivores (horse, kangaroo, hare/rabbit, donkey, zebra, groundhog), omnivores (pig, wild boar), carnivores (dog, cat, coyote, opossum, otter) and birds (chicken, duck, geese, pigeons, starlings, turkey, gull and other wild birds) (Reischer et al., 2013). Overall, sensitivity and specificity of BacH qPCR was reported to be $77 \%$ and $53 \%$ as it was detected in 47 (out of 61 ) human faecal samples and 44 (out of 79) ruminant samples, 9 (out of 28) non-ruminant herbivore samples, 9 (out of 29) omnivore samples, 23 (out of 39) carnivore samples and 18 (out of 44) bird samples (Reischer et al., 2013). The concentration of BacH qPCR marker in human faeces ranged from not detectable to $\sim 7 \log _{10}$ marker copies per reaction, with reported median concentration of $\sim 1.9 \log _{10}$ (Reischer et al., 2013). Levels in non-target animal groups ranged from not detectable to $\sim 4.5 \log _{10}$ marker copies per reaction. Authors also expressed concentration data normalized to 1 nanogram of total DNA. 
In that instance, BacH qPCR marker levels in target sources ranged from not detectable to $\sim 5.5 \log _{10}$ (median $\sim 1$ ), while levels in non-target animal groups ranged from not detectable to $\sim 3.8 \log _{10}$ (Reischer et al., 2013). A previously described study from India reported sensitivity of the BacH TaqMan assay as 17\%, irrespective of the DNQ classification as it was detected in $13.3 \%$ human faeces (from healthy individuals), $40 \%$ of wastewater samples and $30 \%$ of human faeces (from individuals with diarrhea) in the following concentrations expressed as mean $\log _{10}$ gene copies per nanogram of total DNA: $2.40 \pm 0.97$ (healthy humans), $2.03 \pm 0.35$ (sewage) and 2.24 \pm 1.03 (humans with diarrhea) (Odagiri et al., 2015). Reported specificity was $83 \%$, regardless of DNQ classification, as the BacH TaqMan marker was detected in $30 \%$ of dog samples $(1.09 \pm 0.87)$ and $70 \%$ of chicken samples $(2.49 \pm 1.22)$ (Odagiri et al., 2015).

\section{A.1.1.5 BacHum-UCD TaqMan qPCR.}

BacHum-UCD is another human-associated marker developed in TaqMan qPCR format that targets 16S rRNA sequences of the Bacteroidales order (Kildare et al., 2007). Initial sensitivity testing indicated $66.7 \%$ and $100 \%$ sensitivity to human faecal samples (12/18) and wastewater samples (14/14), respectively (Kildare et al., 2007). The assay product was not detected in faecal samples from four non target animal groups $(\mathrm{n}=33)$, but it was detected in one of eight dog faecal samples (Kildare et al., 2007). BacHumUCD qPCR was evaluated in different countries and in several method performance studies. Silkie and Nelson tested performance of the BacHum-UCD marker in California on raw sewage samples and pooled samples from four non-target groups (Silkie and Nelson, 2009). The BacHum-UCD marker was detected in all sewage samples (12 out of 12) with a mean concentration of $8.9 \log _{10}$ gene copies/100mL of sewage. The BacHum-UCD marker crossreacted with cow, horse and dog as it was detected in 1 (out of 11 cow pools resulting from 115 pooled samples) at $7.5 \log _{10}$ gene copies/gram of dry weight faeces, 2 (out of 10 horse pools resulting from 85 individual samples) at 5.3 $\log _{10}$ gene copies/gram of dry weight of faeces, 9 (out of 10 dog pools resulting from 67 individual samples) at $7.6 \log _{10}$ gene copies/gram of dry weight faeces (Silkie and Nelson, 2009). The BacHum-UCD marker was not detected in Canada geese samples (10 pools resulting from 94 individual samples). Another California based study tested performance of BacHum-UCD qPCR assay against a range of human sources (faeces, septage, sewage) and faeces from four non-target groups (Van De Werfhorst et al., 2011). The BacHum-UCD marker was detected in all human sources ( 8 faeces, 3 septage and 10 sewage samples) in concentrations (reported as gene copies) ranging from $6.4 \mathrm{x}$ $10^{4}$ to $5.1 \times 10^{8} / \mathrm{gram}$ wet weight (faeces), from $4.2 \times 10^{4}$ to $6.5 \times 10^{8} / \mathrm{L}$ (septage) from $6.0 \times 10^{7}$ to $8.5 \times 10^{9} / \mathrm{L}$ (sewage) (Van De Werfhorst et al., 2011). The BacHum-UCD marker was also found to cross-react with 10 cat samples (out of 12) with concentrations ranging from $2.0 \times 10^{3}$ to $3.9 \mathrm{x}$ $10^{5} / \mathrm{gram}$ of wet weight (faeces), 9 (out of 12 dog samples) ranging from $1.4 \times 10^{4}$ to $8.9 \times 10^{5}$, in one (out of 3 ) gull samples ( $4.4 \times 10^{2}$ per wet weight) and in two (out of five) raccoon samples ranging from $1.1 \times 10^{4}$ to $1.5 \times 10^{5} / \mathrm{gram}$ of wet weight (Van De Werfhorst et al., 2011). The BacHumUCD marker was not detected in rat faecal samples. The California based method comparison study reported sensitivity $(n=72)$ and specificity $(n=156)$ as $97 \%$ and $37 \%$ when DNQ was considered positive or as $97 \%$ and $67 \%$ when DNQ was considered negative (Layton et al., 2013). When different types of human sources were considered separately, sensitivity was $100 \%$ for all three when DNQ samples were interpreted as positive and it ranged from $92 \%$ (sewage) to $100 \%$ (human faeces and septage) when DNQ samples were considered negative (Layton et al., 2013). The concentration of the BacHum-UCD marker in target and non-target sources varied by the unit of measure used and median values reported were $7.1 \pm 1 / 2.4 \pm 1.7 / \mathrm{mg}$ of wet weight, $2.7 \pm 1.7 / 0 \pm 1.7 / \mathrm{ng}$ of total DNA, $3 \pm 1.3 /-0.6 \pm 1.3 /$ culturable enterococci (USEPA, 2006), $-0.4 \pm 1.5 /-2.9 \pm 1.3 /$ enterococci qPCR (Haugland et al., $2005), \quad 1.9 \pm 1.1 /-1.3 \pm 1.8 /$ culturable E. coli, $1 \pm 0.9 /-2.2 \pm 1.7 / E$. coli qPCR (Chern et al., 2011), $-1.2 \pm 0.4 /-3.9 \pm 1.9 /$ GenBac3 qPCR (Siefring et al., 2008) and $-0.4 \pm 0.2 /-3.8 \pm 2.3 /$ BacUni-UCD qPCR (Kildare et al., 2007). The previously described global method evaluation study reported overall sensitivity and specificity as $87 \%$ and $68 \%$, respectively (Reischer et al., 2013). The BacHum-UCD marker was detected in 53 (out of 61) human faecal samples, 22 (out of 79) ruminant samples, 13 (out of 28) nonruminant herbivores, 6 (out 29) omnivores, 22 (out of 39) carnivores and 8 (out of 44) birds (30). Concentration in target and non-target sources expressed as $\log _{10}$ marker copies per reaction ranged from not detectable to $\sim 6$ (median 2.5) for human sources and from not detectable to $\sim 5$ for non-target sources (Reischer et al., 2013). When data was expressed as $\log _{10}$ per nanogram of total DNA, levels in human faeces ranged from not detectable to $\sim 5$ (median $\sim 1.8$ ) and in non-targets from not-detectable to $\sim 4$ ((Reischer et al., 2013). A study conducted in India reported sensitivity as $49 \%$ or $29 \%$, depending whether DNQ samples were considered positive or negative as it was detected in $40 \%$ of human faeces (from healthy individuals or individuals with diarrhea) and $100 \%$ of sewage samples (Odagiri et al., 2015). Concentrations were reported as mean $\log _{10}$ gene copies/ng of total DNA: $2.46 \pm 1.61$ (healthy humans), $2.20 \pm 0.75$ (sewage) and $2.27 \pm 1.06$ (humans with diarrhea) (Odagiri et al., 2015). BacHum-UCD assay specificity was 78\% (DNQ positive) or $80 \%$ (DNQ negative) since it was detected in $10 \%$ of buffalo samples, $10 \%$ of goat samples, $40 \%$ of dog samples, and $70 \%$ of chicken samples (Odagiri et al., 2015).

A.1.1.6 1,6-Alpha Mannanase Bacteroides thetaiotamicron TaqMan qPCR.

A TaqMan qPCR method targeting the 1,6-alpha mannanase gene from Bacteroides thetaiotamicron is reported by the developing laboratory, to exhibit a specificity of $100 \%$ (8 non-human animal species; $n=283$ individual samples) with a sensitivity of $100 \%$ for both human faecal samples $\left(\mathrm{n}=10\right.$; range $6.88 \times 10^{2}-1.07 \times 10^{9}$ copies/g wet faeces) and sewage $\left(n=20 ; 1.34 \times 10^{1}-4.57 \times\right.$ $10^{2}$ copies/ng of total DNA) (Yampara-Iquise et al., 2008). The performance of the TaqMan assay targeting 1,6-alpha mannanase gene from Bacteroides thetaiotamicron was 
evaluated in the California based method performance study as well (Layton et al., 2013). Reported sensitivity $(\mathrm{n}=12)$ and specificity $(\mathrm{n}=26)$ were $100 \%$ and $54 \%$ when DNQ were considered positive and $92 \%$ and $96 \%$ when DNQ were considered negative. Considering sensitivity results by the animal group source, it was reported as $100 \%$ with DNQ results considered positive and it ranged from $75 \%$ (sewage) to $100 \%$ (human faeces, septage) when DNQ results were considered negative (Layton et al., 2013). Abundance in target and non-target samples was $5.3 \pm 0.1 / 0.9 \pm 0.7 / \mathrm{mg}$ of wet weight, $1 \pm 1.4 /-0.9 / 0.4 / \mathrm{ng}$ of total DNA, $1.4 \pm 0.9 /-1.1 \pm 1.2 /$ culturable enterococci (USEPA, 2006), -0.2 $\pm 1.9 /-2.8 \pm 1.2 /$ enterococci qPCR (20), $0.2 \pm 0.9 /-3.7 \pm 1.6 /$ culturable E. coli and $-0.6 \pm 0.5 /-4.3 \pm 1.2 / E$. coli qPCR (Chern et al., 2011). Another study evaluated concentrations of 1,6-alpha mannanase gene quantified by TaqMan qPCR and expressed as cell equivalents (CE) in raw sewage (RS), primary wastewater effluent $(\mathrm{PE})$, secondary wastewater effluent (SE) and tertiary wastewater effluent (TE) as well as specificity tested against 226 non-human faecal samples originating from bird, cow, cat, dog, horse and pig faeces. Average $\log _{10} \mathrm{CE} / 100 \mathrm{~mL}$ ( \pm standard deviation) of 1,6-alpha mannanase gene were $6.63 \pm 0.51(\mathrm{RS}), 6.75 \pm 0.40(\mathrm{PE})$, $4.13 \pm 0.84(\mathrm{SE})$ and $3.59 \pm 1.12$ (TE) (Srinivasan et al., 2011). Regrettably, results from the specificity testing were not reported (Srinivasan et al., 2011).

\section{A.1.1.7 HumM2 TaqMan qPCR.}

The HumM2 TaqMan qPCR method is another useful human-associated technology with a reported specificity of $97.2 \%$ (21 non-human animal species; $\mathrm{n}=249$ individual samples) with $100 \%$ sensitivity in both human faecal samples $(\mathrm{n}=16)$ and untreated sewage $(\mathrm{n}=20$; median $\sim 2.8$ $\log _{10}$ copies/ng of total DNA) (Shanks et al., 2009). The performance of the HumM2 qPCR assay was evaluated in the United States studies and in India (Odagiri et al., 2015). In the first report, the HumM2 marker was detected in 54 (out of 54) wastewater samples in the concentrations ranging from $1.8 \log _{10}$ to $\sim 3.5 \log _{10}$ gene copy number per nanogram of total DNA, as well as 16 (out of 16) individual human faecal samples $\left(3.42 \pm 0.05 \log _{10}\right.$ gene copies per nanogram of total DNA) (Shanks et al., 2010). Crossreactions were observed with sheep and elk samples with reported mean concentrations of $2.25 \pm 0.05$ and $1.82 \pm 0.05$ $\log _{10}$ gene copies/ng of total DNA, respectively (Shanks et al., 2010). The HumM2 marker was not detected in 20 other non-target animal hosts. Layton and collaborators reported HumM2 assay sensitivity $(\mathrm{n}=72)$ and specificity $(n=156)$ values as $93 \%$ and $75 \%$ when DNQ were considered positive and as $67 \%$ and $94 \%$ when DNQ were considered negative. Considering sensitivity on the basis of three human sources, reported values range from $83 \%$ (sewage), to $96 \%$ (septage) to $100 \%$ when DNQ samples are considered positive and from $46 \%$ (sewage) to $54 \%$ (septage) to $100 \%$ when DNQ samples are considered negative (Layton et al., 2013). The concentration of HumM2 marker in target and non-target sources was $5.3 \pm 0.3$ and $0.8 \pm 0.9 / \mathrm{mg}$ wet weight, $0.9 \pm 1.4$ and $-1.1 \pm 0.7 / \mathrm{ng}$ of total DNA, $1.1 \pm 1$ and $-0.9 \pm 0.8 /$ culturable enterococci (USEPA, 2006), $-1.6 \pm 1.7$ and $-3.7 \pm 1.3$ /enterococci qPCR (Haugland et al., 2005), $0.2 \pm 0.7$ and $-2.6 \pm 1.2 /$ culturable E. coli, $-0.8 \pm 0.5$ and $-3.2 \pm 0.7 / E$. coli qPCR (Chern et al., 2011), $-2.9 \pm 0.7$ and $-6.2 \pm 1.9 /$ GenBac qPCR (Siefring et al., 2008). A study from India reported sensitivity as $49 \%$ (DNQ positive) or $26 \%$ (DNQ negative) since the HumM2 TaqMan assay was detected in $40 \%$ of samples from healthy humans and $100 \%$ of sewage samples (as well as $10 \%$ of samples from humans with diarrhea) (Odagiri et al., 2015). Mean $\log _{10}$ concentrations/ng of total DNA in target sources were as follows: $1.57 \pm 0.67$ (healthy human), 1.95 (sewage) and $1.99 \pm 0.97$ (humans with diarrhea). Specificity varied from $70 \%$ to $92 \%$, depending on whether DNQ samples were considered positive or negative (Odagiri et al., 2015). The HumM2 TaqMan marker was detected in $10 \%$ of cow samples (none within quantifiable range), $60 \%$ of goat samples $(2.17), 30 \%$ of sheep samples (none within quantifiable range), $20 \%$ of dog samples $(0.81)$, and $60 \%$ of chicken (0.88 \pm 0.36$)$ samples (Odagiri et al., 2015).

\section{A.1.2 Methanogens}

\section{A.1.2.1 nifH End-Point PCR.}

The nifH end-point PCR method is reported (by the developing laboratory) to have a specificity of $100 \%$ (10 non-human animal species; $\mathrm{n}=204$ individual samples total) with a sensitivity ranging from $29 \%$ in human faecal samples $(n=70)$ to $93 \%$ in sewage $(n=27)$ (Ufnar et al., 2006). Sensitivity and specificity of the nifH end-point marker has been reported to date only in the United States. A Florida based study tested nifH end-point PCR specificity on individual samples from 13 non-target hosts, as well as two farm composite samples (McQuaig et al., 2009). Sensitivity was tested against 16 on-site collection samples, 39 wastewater influents and nine dechlorinated tertiarytreated wastewater effluents (McQuaig et al., 2009). The nifH end-point PCR marker was detected only in one (out of 24) individual cow samples and was detected in nearly all target samples, except one septic tank sample, but not in any final effluent samples (McQuaig et al., 2009). In another Florida based study, performance of nifH end-point PCR assay was tested against 343 individual and composite samples from 10 non-target groups and 44 target samples (19 wastewater samples and 25 on-site collection samples) (Harwood et al., 2009). The nifH end-point PCR marker was reported as $98 \%$ specific as it cross-reacted with two cow samples (out of 77), one dog sample (out of 100) and 2 seagull samples (out of 58), but was $100 \%$ sensitive as it was detected in all target samples (Harwood et al., 2009).

\section{A.1.2.2 nifH TaqMan qPCR}

A nifH TaqMan qPCR showed increased sensitivity (100\%; $n=16$ ambient water samples with known sewage input; $1.2 \times 10^{1}-3.8 \times 10^{3}$ genome equivalents $/ 100 \mathrm{~mL}$ ambient water), but reduced specificity (50\%; four ambient water samples spiked with same bird guano preparation) as reported by the developing laboratory (Johnston et al., 2010). Layton and collaborators tested sensitivity and specificity of the nifH TaqMan assay in a California based method comparison study (Layton et al., 2013). When results were interpreted with DNQ considered positive or 
negative, sensitivity $(\mathrm{n}=60)$ was $78 \%$ and $60 \%$, respectively while specificity $(n=130)$ was $68 \%$ and $76 \%$, respectively (Layton et al., 2013). Additionally, when different human sources were considered separately sensitivity ranged from $55 \%$ (sewage) to $85 \%$ (septage) to $95 \%$ (sewage) with DNQ samples interpreted as positive (Layton et al., 2013). When DNQ samples were considered negative sensitivity ranged from $20 \%$ (sewage) to $65 \%$ (septage) to $95 \%$ (human faecal samples) (Layton et al., 2013). Abundance of nifH qPCR $\left(\log _{10}\right.$ transformed median value) in target samples ranged from $5.7 \pm 0.5$ per milligram of wet weight, $1.3 \pm 1.6$ per nanogram of total DNA, $2 \pm 1.2$ per culturable enterococci (USEPA, 2006), -2.3 \pm 2.1 per enterococci qPCR (Haugland et al., 2005)(, 0.2 \pm 1.1 per culturable E. coli assayed via membrane filtration, $-0.5 \pm 0.9$ per $E$. coli qPCR (Chern et al., 2011) and $-3.1 \pm 0.8$ per GenBac3 qPCR (Siefring et al., 2008). Median $\log _{10}$ values in non-target samples were $3.4 \pm 1.2 / \mathrm{mg}$ of wet weight, $0.8 \pm 1.3 / \mathrm{ng}$ of total DNA, $1.6 \pm 2.2$ /culturable enterococci (USEPA, 2006), $-1.9 \pm 2.2$ /enterococci qPCR (Haugland et al., 2005), $-0.7 \pm 1.9 /$ culturable E. coli, $-1.3 \pm 1.7 / E$. coli qPCR (Chern et al., 2011) and $-4.5 \pm 1.3 /$ GenBac3 qPCR (Siefring et al., 2008).

\section{A.1.3 Bifidobacterium}

\section{A.1.3.1 B. adolescentis End-Point PCR}

A multiplex end-point PCR assay targeting 16S rRNA genes from $B$. adolescentis (ADO) and B. dentium (DEN) exhibited $100 \%$ specificity (3 non-human faecal samples; 8 individual samples total) (Bonjoch et al., 2004). The sensitivity of ADO (100\%) was slightly better than that of DEN (91.7\%) when tested against 12 sewage samples (Bonjoch et al., 2004). In addition to the developing laboratory located in Spain, the multiplex end-point PCR assay targeting $B$. adolescentis was also tested on samples collected from Spain, France, Sweden, United Kingdom, Cyprus and the United States. A Spain based study performed sensitivity and specificity testing on a total of 230 samples (Blanch et al., 2006). Sensitivity testing was carried out on 114 wastewater samples collected from municipal wastewater $(n=77)$, hospital wastewater $(n=21)$ and military camp wastewater $(n=17)$ and the $B$. adolescentis end-point PCR marker was not detected in $6.3 \%$ of human derived samples (Blanch et al., 2006). Specificity was also lower, since the assay cross-reacted with $24.5 \%$ of animal samples comprised from slaughterhouse wastewater $(n=57)$ and farm slurries $(n=59)$ from different non-target groups (cattle, sheep, pigs, horses and poultry) (Blanch et al., 2006). A subsequent study also conducted in Spain, tested performance of the $B$. adolescentis end-point PCR assay on sewage samples from nine wastewater treatment plants, poultry wastewater effluents, swine faeces and slurry, ruminant slaughter houses and bovine farms (Balleste et al., 2010). The B. adolescentis end-point PCR marker was detected in $95.6 \%$ of wastewater effluents (43 out of 45 ), and was found to be $74.3 \%$ specific as it cross-reacted with $35.3 \%$ cow samples ( 6 out of 17 ), $18.2 \%$ poultry samples (4 out of 22 ), and $25.7 \%$ of swine samples (9 out of 35 ) (Balleste et al., 2010). Limited data exists in the performance of marker in the United States. When tested on raw sewage samples and against 22 samples from five non-target groups, the $B$. adolescentis end-point PCR marker was detected in two (out of three) sewage samples and three (out of 8) pig samples (Bachoon et al., 2010).

\section{A.1.3.2 B. adolescentis TaqMan qPCR}

A TaqMan qPCR assay that targets the 16S rRNA gene from $B$. adolescentis was subsequently developed with a reported specificity of $94.5 \%$ (6 non-human animal species; $\mathrm{n}=67$ individual samples total) and sensitivity ranging from $90 \%$ in human faecal samples $\left(n=10 ; 5 \times 10^{5}-1 \times 10^{9} \log _{10}\right.$ gene copies/g) to $100 \%$ in sewage $\left(n=8 ; 1 \times 10^{4}-7.9 \times 10^{6} \log _{10}\right.$ gene copies/gram) (Gourmelon et al., 2010). No performance evaluations of $B$. adolscentis TaqMan qPCR assay were performed to date, aside from the initial developing laboratory report.

\section{A.1.4 Enterococcus}

\section{A.1.4.1 esp Gene E. faecium End-Point PCR.}

An end-point PCR assay targeting the Enterococcus surface protein (esp) from Ent. faecium exhibited 100\% specificity (8 animal groups; $\mathrm{n}=102$ individual samples) with sensitivity values ranging from $100 \%$ sensitivity in sewage samples $(n=55)$ to $80 \%$ in septage samples $(n=10)$ (Scott et al., 2005). An assay targeting the esp gene of $E$. faecium was tested in the United States, Spain and Australia. A Florida based study, tested sensitivity and specificity of the esp gene E. faecium end-point PCR assay on wastewater samples and individual samples $(n=59)$ from two non-target groups (Korajkic et al., 2009). The esp gene E. faecium end-point PCR marker was detected in all sewage samples $(n=3)$, but it cross-reacted with three seagull samples (out of 39) and one dog sample (out of 20) (Korajkic et al., 2009). In a California study, the esp gene $E$. faecium end-point PCR assay was tested against sewage samples and individual human faecal samples, as well as samples from five non-target hosts (Layton et al., 2009). Sensitivity of the esp gene E. faecium end-point PCR assay was reported as $92 \%$ as it was detected in 24 (out of 26) wastewater samples and it was also detected in ten (out of 12) individual human faecal samples (Layton et al., 2009). The esp gene E. faecium end-point PCR assay cross-reacted with $64 \%$ of non-target samples including all 16 dog samples, eight (out of 22) seagull samples, nine (out of 16) horse, 9 (out of 14) sea lion and all four seal samples (Layton et al., 2009). Increased performance was reported in a Michigan study where sensitivity was tested against untreated and treated wastewater, as well as sludge and on-site septic systems while specificity was tested against individual and composite samples from three non-target groups (Masago et al., 2011). The esp gene E. faecium endpoint PCR marker was detected in all septic tank samples $(n=6), 90 \%$ of untreated wastewater samples $(9 / 10), 20 \%$ of treated wastewater samples (2/10), but not the wastewater sludge sample $(n=1)$ nor any non-target samples $(n=17)$ (Masago et al., 2011). The performance of the esp gene $E$. faecium end-point PCR assay was not as good in a Spanish study with reported sensitivity of $77 \%$ (10 out of 13 ) to 
wastewater samples and specificity of $68 \%$ as it crossreacted with ten (out of 13) pig samples and one (out of five) cow samples (Balleste et al., 2010). An Australian based study tested esp gene E. faecium end-point PCR assay performance with wastewater and faeces from 24 non-target species (Neave et al., 2014). The esp gene $E$. faecium end-point PCR marker was detected in all wastewater samples tested, as well as samples collected from species of wallaby, one species of wallaroo and a monkey (Neave et al., 2014). An end-point PCR assay targeting the Enterococcus surface protein (esp) from $E$. faecium exhibited $100 \%$ specificity (8 animal groups; $\mathrm{n}=102$ individual samples) with sensitivity values ranging from $100 \%$ sensitivity in sewage samples $(n=55)$ to $80 \%$ in septage samples $(n=10)(60)$.

\section{A.1.4.2 esp gene E. faecium SYBR Green qPCR}

The method was later adapted to a SYBR Green qPCR chemistry with a reported sensitivity of $100 \% \quad(n=16$ wastewater samples; $9.8 \times 10^{3}-3.8 \times 10^{4}$ gene copies $/ 100 \mathrm{~mL}$ ) (Ahmed et al., 2008). Performance of the SYBR Green esp qPCR assay was evaluated only in Australia to date (Ahmed et al., 2009). Authors tested 32 wastewater samples, as well as individual and composite samples from five non-target animal groups $(n=50)$. The esp gene $E$. faecium SYBR green qPCR assay was reported to be $100 \%$ sensitive and specific (Ahmed et al., 2009).

\section{A.2.0 Ruminant}

\section{A.2.1 Bacteroidales}

\section{A.2.1.1 CF193 End-point PCR}

When originally developed, CF193 exhibited 100\% specificity ( 6 non-ruminant animal species; $n=28$ individual samples total) with a sensitivity of $100 \%$ (6 ruminant or pseudo-ruminant animal species; $\mathrm{n}=31$ individual samples total) (Bernhard and Field, 2000). In addition to the developing laboratory (located in the United States), the performance of the CF193 end-point ruminant MST assay has been tested by other laboratories in the United States (Raith et al., 2013; Shanks et al., 2010), as well as France (Gourmelon et al., 2007) and Spain (Balleste et al., 2010). Further testing in the US was carried out using 247 individual bovine faecal samples, as well as 175 faecal samples representing 24 different non-target animal species (Shanks et al., 2010). The CF193 end-point PCR assay was reported to be $99.9 \%$ specific as it cross-reacted with one horse sample (out of 7 tested) (Shanks et al., 2010). Overall prevalence of the CF193 end-point PCR marker was reported at $68 \%$ when tested against 11 different cattle herds, but ranged from none detected to $100 \%$ in individual samples within a population (Shanks et al., 2010). A multiple laboratory validation study conducted in the United States tested performance of the CF193 endpoint PCR assay against pooled samples collected from over 100 individuals and representing 10 different species (human, horse, cow, deer, pig, goose, chicken, pigeon, gull and dog)(Raith et al., 2013). The CF193 end-point PCR assay was reported to be $67 \%$ sensitive and $94 \%$ specific
(Raith et al., 2013). A French study tested sensitivity and specificity on individual faeces from humans $(n=44)$, cows $(n=32)$, sheep $(n=12)$, chickens $(n=10)$, wild birds $(n=7)$ as well as 10 pig liquid manure samples, six sewage sludge (solids) and five sewage sludge liquid samples (Gourmelon et al., 2007). The ruminant CF193 end-point PCR marker was detected in all cow samples and 10 sheep samples, but was absent from all other non-target samples (Gourmelon et al., 2007). The CF193 end-point PCR marker was also not detected in any sludge or pig liquid manure samples (Gourmelon et al., 2007). A Spanish study reported considerably lower sensitivity values $(0 \%)$ as the CF193 end-point PCR marker was not detected in any of the 19 cow faecal samples, but sensitivity was relatively high $(99 \%)$ as it was absent from faecal samples of humans $(n=39)$, swine $(n=29)$ and present in one (out of 26) poultry samples (Balleste et al., 2010).

\section{A.2.1.2 Rum2Bac TaqMan qPCR}

As reported by the developing laboratory, the Rum2Bac method showed $97 \%$ sensitivity (2 ruminant animal species and bovine manure; $\mathrm{n}=30$ individual samples; averages of 7.0 $\pm 0.5-8.1 \pm 0.5 \log _{10}$ copies/gram) with a specificity of $100 \%$ (4 non-ruminant animal species; $\mathrm{n}=40$ ) (Mieszkin et al., 2010). The performance of the French ruminant Rum2Bac TaqMan marker was evaluated in the comprehensive United States method evaluation study described earlier (Raith et al., 2013). The reported sensitivity and specificity were both $100 \%$ with mean $\log _{10}$ gene copies in target sources ranging from 6.17 to 7.64 and $<0.1$ in non-target sources (Raith et al., 2013). Sensitivity and specificity data, as well as abundance in target and non-target samples were considered using different thresholds for a positive detection including raw data (all detections scored a positive), lower limits of quantification (LLOQ; 10 copies/reaction), 1 nanogram of total DNA, 5,000 copies per reaction of GenBac3 TaqMan qPCR marker (22), 104 MPN enterococci per reaction, or $0.1 \mathrm{mg}$ wet weight of faecal material (Raith et al., 2013). Regardless of detection definition, sensitivity and specificity remained $100 \%$ with abundance expressed as mean $\log _{10}$ copies in target/non-target sources measuring $5.25 /<0.1,4.25 /<0.1$ and $4.31 /<0.1$ using LLOQ, 1 ng total DNA and $0.1 \mathrm{mg}$ wet weight as thresholds, respectively (Raith et al., 2013). However, specificity and abundance in target/non-target sources differed by detection definition: $97 \%$ specificity (false positive results with septage) and $5.25 / 0.80$ with raw instrument data, $97 \%$ specificity and $3.35 /<0.1$ with 5,000 copies of GenBac3 TaqMan qPCR, $97 \%$ specificity (false positive results with septage) and 5.72/2.07 with 104 MPN enterococci (Raith et al., 2013).

\section{A.2.1.3 BacR Taqman qPCR}

Another TaqMan qPCR method targeting a different region of the 16S rRNA gene from ruminant-associated Bacteroidales (BacR) was found to be $100 \%$ sensitive ( 7 ruminant animal species; $\mathrm{n}=57$ individual samples; average $4.1 \times 10^{9}$ marker equivalents/g wet faeces) and did not crossreact with faecal samples collected from 11 non-ruminant animal species $(n=131$ individual or pooled samples) 
(Reischer et al., 2006). In addition to the original developing laboratory study on BacR TaqMan qPCR assay reported by Austrian researchers, performance metrics were determined in France (Mieszkin et al., 2009), United States (Raith et al., 2013), Israel (Ohad et al., 2015), Canada (Ridley et al., 2014), and in a global method evaluation study with reference samples from Argentina, Austria, Australia, Ethiopia, Germany, Hungary, Korea, Nepal, Netherlands, Romania, Spain, Sweden, Tanzania, Uganda and United Kingdom (Reischer et al., 2007). A French study tested performance of the BacR TaqMan marker on pig samples (faeces, slurry, lagoon water and compost), as well as individual bovine $(n=10)$, ovine $(n=10)$, equine $(n=10)$ and human $(n=24)$ faecal samples (Mieszkin et al., 2009). Reported sensitivity was $100 \%$ as the BacR TaqMan marker was detected in all ruminant samples with an average estimated concentration of $10 \pm 0.3 \log _{10}$ copies/gram of wet faeces (Mieszkin et al., 2009). Reported specificity was $89 \%$, since BacR TaqMan was detected in $17 \%, 28 \%$ and $43 \%$ of pig slurry, lagoon water and compost samples, as well as $4 \%$ of human faecal samples (Mieszkin et al., 2009). A Canadian study evaluated performance of the BacR TaqMan assay by testing it against bovine $(n=26)$, chicken $(n=1)$, horse $(n=2)$ and pig $(n=3)$ faecal samples, as well as an unspecified number of wild animal samples, liquid dairy manure $(n=2)$, liquid porcine manure $(n=3)$, and 11 septic tank samples (Ridley et al., 2014). Reported sensitivity and specificity were $94.4 \%$ (one false negative result) and $93.9 \%$ (detection in septic tank and chicken faecal samples), respectively with an average concentration in ruminant faeces of $1.94 \times 10^{8}$ copies/gram (Ridley et al., 2014). An Israeli study reported sensitivity and specificity of BacR TaqMan assay as $100 \%$ and $99 \%$ when tested against an unspecified number of target and non-target animals (Ohad et al., 2015). The previously described United States method comparison study also tested performance metrics of BacR TaqMan assay (Raith et al., 2013). Reported sensitivity and specificity values were $100 \%$ and $58-100 \%$, with abundance in target/non-target hosts of $6.17-7.64 /<0.1-1.87$ mean $\log _{10}$ copies (Raith et al., 2013). Employing different detection definitions resulted in a wider range of values. When raw data were examined, sensitivity was $100 \%$, while specificity was $85 \%$ (false positive results observed with chicken, dog, human and septage samples) and levels in target/non-target sources were $3.91 /<0.1$ mean $\log _{10}$ copies (Raith et al., 2013). Both sensitivity and specificity were $100 \%$ when a LLOQ definition was used with levels in targets/non-targets reported at 3.91 and $<0.1$ mean $\log _{10}$ copies (Raith et al., 2013). Sensitivity remained the same when $1 \mathrm{ng}$ of total DNA was used as a threshold, while specificity was $97 \%$ as chicken sample(s) provided false positives; levels in targets/non-targets were 3.10 and 0.88 mean $\log _{10}$ copies (Raith et al., 2013). Using 5,000 copies of GenBac3 TaqMan qPCR marker, 104 MPN enterococci, or $0.1 \mathrm{mg}$ wet weight per reaction resulted in sensitivity of $100 \%$, but specificity ranged from $97 \%$ due to false positive(s) in chicken samples (enterococci and wet weight) to $100 \%$ (GenBac3 TaqMan qPCR) (Raith et al., 2013). Levels in target/non-target samples were as follows: 2.49/1.48 for GenBac3, 4.88/1.79 for enterococci and 3.47/2.42 for wet weight definitions (Raith et al., 2013). A global method evaluation study described earlier reported overall sensitivity and specificity values as $90 \%$ and $84 \%$, respectively as the BacR TaqMan marker was detected in 71 (out of 79) ruminant samples, 4 (out of 28) non-ruminant herbivores, 2 (out of 29) omnivores, 12 (out of 39) carnivores, 9 (out of 44) birds, and 5 (out of 61) humans (Reischer et al., 2013)(30). Concentrations in target and non-target sources was expressed as $\log _{10}$ gene copies/reaction ranging from not detectable to $\sim 7$ (median $\sim 3$ ) for ruminant sources and from not detectable to $\sim 5$ for non-target sources (Reischer et al., 2013). When data was expressed as $\log _{10} /$ nanogram of total DNA, levels in ruminant faeces ranged from not detectable to $\sim 6$ (median $\sim 2.2$ ) and in non-targets from not-detectable to $\sim 4$ (Reischer et al., 2013).

\section{A.2.1.4 CowM2 End-point and TaqMan qPCR}

As reported by the developing laboratory, CowM2 endpoint PCR method exhibited $80 \%$ sensitivity to cattle faecal samples $(n=148)$ and $100 \%$ specificity when tested against 26 animal species $(n=279$ individual samples) (Shanks et al., 2006). TaqMan qPCR version of the method demonstrated increased levels of specificity (100\%) when tested against 15 non-cattle animal hosts $(n=201)$ and similar sensitivity levels (100\%) when tested against 60 individual cattle faecal samples (Shanks et al., 2008). The performance of CowM2 end-point PCR and TaqMan qPCR assays have been further evaluated in the United States (Raith et al., 2013; Shanks et al., 2010), Canada (Ridley et al., 2014), Israel (Ohad et al., 2015) and India (Odagiri et al., 2015). The first United States based study is the only study that performed evaluation on both CowM2 end-point PCR and qPCR assay chemistries (Shanks et al., 2010). Reported specificities for both end-point and TaqMan formats were $100 \%$ as neither marker was detected in any of the non-target groups tested (175 individual faecal samples from 24 different animal groups) (Shanks et al., 2010). Prevalence of the CowM2 end-point PCR assay in target species ranged from none detected to $100 \%$ when 11 different herds were examined (Shanks et al., 2010). Levels in target species for CowM2 TaqMan assay ranged from none detected to $\sim 1$ estimated $\log _{10}$ mean copy number/ng of total DNA (Shanks et al., 2010). A United States multiple laboratory method validation study reported sensitivity $(100 \%)$ and specificity $(97-100 \%)$, as well as mean $\log _{10}$ copy number in target (4.80-5.48) and non-target sources $(<0.1$ to 2.69) (Raith et al., 2013). Examining results by the different detection definitions netted the following results in the subsequent order (sensitivity/specificity/abundance in target and non-target sources expressed as mean $\log _{10}$ copies): $100 \% / 100 \%, 3.14$ and $<0.1$ when considering raw instrument data, $100 \% / 100 \%, 3.14$ and $<0.1$ when considering data above LLOQ, 75\%/100\%, 2.25 and $<0.1 / \mathrm{ng}$ of total DNA, 50\%/100\%, 1.63 and $<0.1 / 5,000$ copies of GenBac3 TaqMan qPCR, 100\%/100\%, 3.78 and $<0.1 / 104$ MPN enterococci, 75\%/100\%, 2.32 and $<0.1 / 0.1 \mathrm{mg}$ wet weight (Raith et al., 2013). A Canada based study reported $100 \%$ specificity of CowM2 TaqMan qPCR assay when tested against chicken $(n=1)$, horse $(n=2)$, pig $(n=3)$ faecal samples along with an indeterminate number of wild animal samples, liquid dairy manure $(n=2)$, liquid porcine manure $(n=3)$ and 11 septic tank samples (Ridley et al., 2014). 
Reported sensitivity was $88.9 \%$ sensitivity (16 out of 18 target samples positive) (Ridley et al., 2014). The average concentration of the CowM2 TaqMan marker in target sources was $1.44 \times 10^{6}$ copies/gram (Ridley et al., 2014). An India based study tested performance metrics of the CowM2 TaqMan qPCR marker as well (Odagiri et al., 2015). When challenged by 30 individual human faecal samples, 5 sewage samples, and 60 pooled animal samples (from cow, buffalo, goat, sheep, dog and chicken) the assay exhibited $50 \%$ sensitivity and $100 \%$ specificity, regardless of whether DNQ samples were considered positive or not (Odagiri et al., 2015). The reported concentration in target sources ranged from $\sim 1$ to $2.2 \log _{10}$ copies/ng of total DNA (Odagiri et al., 2015). An Israel based study reported sensitivity/specificity of CowM2 TaqMan assay as 50\% and $89 \%$, regrettably the number and type of target and nontarget sources, as well as levels in target/non-target sources were not reported (Ohad et al., 2015).

\section{A.2.1.5 CowM3 End-point and TaqMan qPCR}

As reported by the developing laboratory, CowM3 endpoint PCR method showed $91 \%$ sensitivity to cattle faecal samples $(n=148)$ and $99 \%$ specificity when tested against 26 animal species ( $\mathrm{n}=279$ individual samples) (Shanks et al., 2006). Similar to CowM2, TaqMan version of CowM3 also showed increased specificity (100\%) and similar sensitivity levels (98\%) when tested against 60 individual cattle faecal samples (Shanks et al., 2008). Sensitivity and specificity of CowM3 marker has been evaluated in the United States (Raith et al., 2013; Shanks et al., 2010), Australia (Ahmed et al., 2013) and Israel (Ohad et al., 2015). Shanks et al. reported specificity of end-point and TaqMan chemistries as $98.9 \%$ (cross-reacted with two alpaca samples) and $100 \%$, respectively when tested against 24 non-target animal groups (Shanks et al., 2010). Prevalence of CowM3 end-point PCR marker in 11 different cattle herds ranged from $0 \%$ to $100 \%$, while levels of CowM3 TaqMan qPCR marker in the same samples ranged from non-detected to $\sim 1 \log _{10}$ estimated target copy/ng of total DNA (Shanks et al., 2010). A multiple laboratory validation study conducted in the United States reported sensitivity and specificity of CowM3 TaqMan qPCR assay as $100 \%$, with levels in target/non-target of 4.52-5.89 and $<0.1$ mean $\log _{10}$ copies (Raith et al., 2013). When different detection definitions were applied, specificity remained $100 \%$, but sensitivity and levels in target and non-target sources varied (Raith et al., 2013). Using raw instrument data, LLOQ, 1 nanogram of the total DNA 5.000 copies of GenBac3 TaqMan qPCR marker, 104 MPN of enterococci and $0.1 \mathrm{mg}$ of wet weight as detection definitions, sensitivity/levels in target and non-target species were as follows: $100 \% / 2.05$ and $<0.1,75 \% / 2.51$ and $<0.1,50 \% / 1.33$ and $<0.1,0 \%$ none detected, $100 \% / 2.69$ and $<0.1$, $50 \% / 1.65$ and $<0.1$ (Raith et al., 2013). An Australian based study evaluated performance of the CowM3 TaqMan qPCR assay with individual faecal samples from cattle $(n=20)$, birds $(n=10)$, chickens $(n=10)$, dogs $(n=10)$, ducks $(n-10)$, kangaroos $(n=10)$, pigs $(n=10)$, possums $(n=10)$, horses $(n=10)$, as well as bovine $(n=20)$ and human wastewaters $(n=20)$ (Ahmed et al., 2013). Sensitivity of the CowM3 TaqMan qPCR assay was reported as $90 \%$ as it was detected in 16 cattle faecal samples and 20 bovine wastewater samples (Ahmed et al., 2013). Specificity was determined to be $90 \%$, as it was detected in five dog samples, four duck samples, and two possum samples (Ahmed et al., 2013). A study conducted in Israel, reported sensitivity and specificity of CowM3 TaqMan assay as 93\% and $99 \%$, respectively (Ohad et al., 2015).

\section{A.3.0 Porcine}

\section{A.3.1 Bacteroidales}

\section{A.3.1.1 PF163 End-point PCR}

When originally developed, the end-point PCR method PF163 exhibited a specificity of 100\% (pooled samples from 10 non-porcine animal species) with a sensitivity of $100 \%$ against two pooled porcine faecal samples (Dick et al., 2005). Performance of the PF163 end-point assay has been evaluated in the US (Toledo-Hernandez et al., 2013; Boehm et al., 2013; Lamendella et al., 2009), Canada (Fremaux et al., 2009) and France (Gourmelon et al., 2007). Lamendella et al. tested 215 faecal samples from pigs, cattle, humans, chicken, raccoons and horses as well as four manure pig pit and three waste lagoon samples (pig and/or cattle) (Lamendella et al., 2009).The assay was detected in all of the pig manure pits and lagoons and in 40 to $100 \%$ of pig faeces tested (Lamendella et al., 2009). PF163 end-point assay was also detected in 40\% (9 out of 20) cattle, 30\% (3 out of 10 ) human, $50 \%$ chicken (4 out of 8 ), $4 \%$ racoon $(3 / 68)$ and $67 \%$ horse (8 out of 12$)$ faecal samples (Lamendella et al., 2009). Puerto Rico study determined sensitivity and specificity of PF163 end-point assay by testing it against 340 faecal samples from cow $(n=66)$, goat $(n=32)$, horse $(n=28)$, swine $(n=30)$, monkey $(n=9)$, fish $(n=12)$, pigeon $(n=11)$, chicken $(n=97)$ and five wastewater samples (Toledo-Hernandez et al., 2013). Marker was detected in all of the pig samples, but it also cross-reacted with $100 \%$ of goat samples, $100 \%$ of horse samples and $80 \%$ of wastewater samples (Toledo-Hernandez et al., 2013). US based multi-laboratory validation study described earlier also performed sensitivity/specificity testing on the PF163 end-point assay and reported both to be greater than $80 \%$ (Boehm et al., 2013). A Canada based study tested PF163 marker against a total of 62 faecal samples from humans (individuals and sewage) and 50 samples from various animals including cow, pig, chicken, goose, moose, caribou, bison, goat and different species of deer. Assay exhibited 100\% sensitivity and specificity (Fremaux et al., 2009). French study detected PF163 in all 25 pig faecal samples tested, as well as all of the pig liquid manure samples tested $(n=10)$ with reported sensitivity of 100\% (Gourmelon et al., 2007). Reported specificity was $98 \%$ as it was detected in two (out of 10) chicken samples but was absent from a44 human faecal samples, 32 cow faecal samples, 12 sheep faecal samples and seven wild bird samples (Gourmelon et al., 2007). PF163 was also not detected in any sewage sludge samples $(n=6)$ or wastewater samples $(n=5)$ (Gourmelon et al., 2007). 


\section{A.3.1.2 Pig2Bac TaqMan qPCR}

The Pig2Bac TaqMan qPCR method demonstrated 100\% sensitivity when tested against pig faecal samples $(n=25$; average $8.5 \pm 0.6 \log _{10}$ copies/gm wet faeces), swine slurries $\left(\mathrm{n}=25\right.$; average $4.9 \pm 0.7 \log _{10}$ gene copies $/ \mathrm{mL}$ ), lagoon waters $\left(\mathrm{n}=14\right.$; average $2.6 \pm 0.4 \log _{10}$ gene copies/mL) and compost ( $\mathrm{n}=14$; average $5.3 \pm 0.6 \log _{10}$ gene copies/gm) and $100 \%$ specificity (4 non-porcine animal species; $n=54$ individual samples as reported by the developing laboratory (Mieszkin et al., 2009). Performance of the Pig2Bac TaqMan qPCR assay was tested in a United States multiple laboratory validation study (Boehm et al., 2013) and in Israel (Ohad et al., 2015). The United States based study reported high sensitivity (100\%, detected in 20 out of 20 pig samples), but low specificity ( $\sim 40 \%$ to $\sim 90 \%$, depending on the laboratory) as it cross-reacted with samples from dog and human faeces, as well as septage (Boehm et al., 2013). Levels in target sources, reported as $\log _{10}$ median in units of copies per colony forming unit (CFU) of enterococci were 5.0 with all 20 samples within range of quantification (Boehm et al., 2013). For the nontarget sources, $73 \%$ were not detected, $44 \%$ were detected but not quantified and 1\% was within quantifiable range, but median was classified as not detected when expressed in $\log _{10}$ median units of copies per enterococci CFU (Boehm et al., 2013). A study conducted in Israel reported both sensitivity and specificity as $100 \%$, but unfortunately nontarget animals tested and levels in target samples were not specified (Ohad et al., 2015).

\section{A.4.0 Avian}

\section{A.4.1 Helicobacter spp.}

\section{A.4.1.1 GFD SYBR Green qPCR}

As originally reported, GFD exhibited $100 \%$ specificity when tested against 16 non-avian animal species $(n=305$ individual samples) and yielded $57 \%$ sensitivity when tested against 15 different avian species $(n=768)$ (Green et al., 2012). In addition to the method developing laboratory, which evaluated method performance in the United States and New Zealand, sensitivity and specificity of the GFD SYBR Green assay was also measured with reference samples from 19 animal groups collected in the United States and Australia (Ahmed et al., 2016). In Australia and the United States, the prevalence of the GFD SYBR Green marker was reported as $58 \%$ and $30 \%$, respectively with mean concentration of $5.2 \times 10^{3}$ gene copies/10 ng of total DNA (Ahmed et al., 2016). Specificity of the GFD SYBR Green marker was higher in the United States (100\%) compared to Australia (94\%) where it cross-reacted with dog, kangaroo, possum and sheep samples with a mean concentration in non-target samples of 56 gene copies/10 nanograms of total DNA (Ahmed et al., 2016).

\section{A.4.2 Catelicoccus spp.}

A.4.1.1 Gull4 TaqMan qPCR

Gull4 is a TaqMan qPCR method that targets the $16 \mathrm{~S}$ rRNA gene of $C$. marimammalium (68). The method was tested for sensitivity against gull faeces $(n=255)$, as well as various poultry and waterfowl species $(n=249)$ and six nonavian species $(n=180)$ (61). Gull4 is reported to be $86.7 \%$ sensitive to gull (average $\sim 1 \times 10^{5}$ copies/ng of total DNA) and $15.3 \%$ for poultry and waterfowl (68). Specificity of the assay was nearly $100 \%$, as it cross-reacted with only one pig faecal sample, but not 179 faecal samples from five other non-avian species (Ryu et al., 2012). No performance evaluations of Catelicococcus spp. Gull4 TaqMan qPCR assay were performed to date, aside from the initial developing laboratory report.

\section{A.4.3 Brevibacterium spp.}

\section{A.4.3.1 LA35 SYBR Green and TaqMan qPCR}

The LA35 SYBR Green chemistry qPCR method targets the 16S rRNA gene from Brevibacterium spp. (Weidhaas et al., 2010). Method sensitivity (76\%) was determined using chicken litter (bedding) $\left(\mathrm{n}=17 ; 1.5 \times 10^{7}-3.7 \times 10^{9}\right.$ gene copies/gm) and individual chicken faecal samples ( $\mathrm{n}=40 ; \geq$ $2.8 \times 10^{4}$ gene copies/gm). In addition, LA35 exhibited 93\% specificity when tested against 116 non-chicken individual faecal samples from five animal species and wastewater (Weidhaas et al., 2010). The method was recently adapted to TaqMan chemistry (Weidhaas et al., 2013), but there are no reports to date that further tested its performance. The performance of LA35 SYBR Green qPCR assay was tested in one United States based study to date. Sensitivity of the method was assessed by testing the assay against chicken litter $(n=40)$ and poultry faecal samples $(n=186)$ (Ryu et al., 2014). Overall, 97.5\% of chicken litter samples and $22.6 \%$ of faecal samples were positive with mean values of $\sim 7$ (litter) and $\sim 3.5$ (poultry faeces) $\log _{10}$ copies/gram of sample (Ryu et al., 2014). The LA35 SYBR Green qPCR marker was detected in $8.9 \%$ of non-poultry avian species (5 out of 16 duck, 5 out of 25 Canada goose, 1 out of 11 guineafowl, 2 out of 64 gull, 1 out of 6 mallard and 3 out of 22 swan samples) (Ryu et al., 2014). Mean $\log _{10}$ copy number/gram of sample from non-poultry avian species was 2.9 (Ryu et al., 2014). The LA35 SYBR Green qPCR marker was not detected in 8 non-target groups or any sewage samples (Ryu et al., 2014). 


\section{References}

Administración Nacional de Medicamentos, A.y.T.M.A (2012). Bebidas Hídricas, Agua y Agua Gasificada.

AFNOR (1985). Essais des eaux - Recherche et dénombrement des coliformes et des coliformes thermotolérants - Méthode générale par ensemencement en milieu liquide (NPP).

Ahmed, W., Goonetilleke, A., Powell, D., Chauhan, K. and Gardner, T. (2009). Comparison of molecular markers to detect fresh sewage in environmental waters. Water Research. 43, pp. 4908-4917.

Ahmed, W., Gyawali, P., Sidhu, J.P. and Toze, S. (2014). Relative inactivation of faecal indicator bacteria and sewage markers in freshwater and seawater microcosms. Letters in Applied Microbiology. 59, pp. 348-354.

Ahmed, W., Harwood, V.J., Nguyen, K., Young, S., Hamilton, K. and Toze, S. (2016). Utility of Helicobacter spp. associated GFD markers for detecting avian fecal pollution in natural waters of two continents. Water Research. 88, pp. 613-622.

Ahmed, W., Sidhu, J.P., Smith, K., Beale, D.J., Gyawali, P. and Toze, S. (2015). Distributions of Fecal Markers in Wastewater from Different Climatic Zones for Human Fecal Pollution Tracking in Australian Surface Waters. Applied and Environmental Microbiology. 82, pp. 1316-1323.

Ahmed, W., Sritharan, T., Palmer, A., Sidhu, J.P. and Toze, S. (2013). Evaluation of bovine feces-associated microbial source tracking markers and their correlations with fecal indicators and zoonotic pathogens in a Brisbane, Australia, reservoir. Applied and Environmental Microbiology. 79, pp. 2682-2691.

Ahmed, W., Stewart, J., Gardner, T. and Powell, D. (2008). A real-time polymerase chain reaction assay for quantitative detection of the human-specific enterococci surface protein marker in sewage and environmental waters. Environmental Microbiology. 10, pp. 3255-3264.

Ahmed, W., Stewart, J., Powell, D. and Gardner, T. (2008). Evaluation of the host-specificity and prevalence of enterococci surface protein $(e s p)$ marker in sewage and its application for sourcing human fecal pollution. Journal of Environmental Quality. 37, pp. 1583-1588.

Ahmed, W., Yusuf, R., Hasan, I., Goonetilleke, A. and Gardner, T. (2010). Quantitative PCR assay of sewage-associated Bacteroides markers to assess sewage pollution in an urban lake in Dhaka, Bangladesh. Canadian Journal of Microbiology. 56, pp. 838-845.

Akiba, M., Senba, H., Otagiri, H., Prabhasankar, V.P., Taniyasu, S., Yamashita, N. et al. (2015). Impact of wastewater from different sources on the prevalence of antimicrobial-resistant Escherichia coli in sewage treatment plants in South India. Ecotoxicology and Environmetal Safety. 115,.

Anderson, K.L., Whitlock, J.E. and Harwood, V.J. (2005). Persistence and differential survival of fecal indicator bacteria in subtropical waters and sediments. Applied and Environmental Microbiology. 71, pp. 3041-3048.

APHA (2012). Standard Methods for the examination of water and wastewater (22nd ed). American Public Health Association. Washington DC.

Ashbolt, N.J., Grabow, W.O.K. and Snozzi, M. (2001). Indicators of microbial water quality. Water Quality - Guidelines, Standards and Health: Assessment of risk and risk management for water-related infectious disease. International Water Association Publishing. Cornwall, UK.

Bachoon, D.S., Miller, C.M., Green, C.P. and Otero, E. (2010). Comparison of four polymerase chain reaction methods for the rapid detection of human fecal pollution in marine and inland waters. Internation Journal of Microbiology. 2010, pp. $1-7$.

Badgley, B.D., Nayak, B.S. and Harwood, V.J. (2010). The importance of sediment and submerged aquatic vegetation as potential habitats for persistent strains of enterococci in a subtropical watershed. Water Research. 44, pp. 5857-5866. 
Bae, S. and Wurtzer, S. (2009). Rapid decay of host-specific fecal Bacteroidales cells in seawater as measured by quantitative PCR with propidium monoazide. Water Research. 43, pp. 4850-4859.

Bahaka, D., Neut, C., Khattabi, A., Monget, D. and Gavini, F. (1993). Phenotypic and genomic analyses of human strains belonging or related to Bifidobacterium longum, Bifidobacterium infantis, and Bifidobacterium breve. International Journal of Systematic Bacteriology. 43, pp. 565-573.

Balleste, E., Bonjoch, X., Belanche, L.A. and Blanch, A.R. (2010). Molecular indicators used in the development of predictive models for microbial source tracking. Applied and Environmental Microbiology. 76, pp. 1789-1795.

Banerjee, G. (2011). Underground pollution travel from leach pits of on-site sanitation facilities: a case study. Clean Technologies and Environmental Policy. 13, pp. 489-497.

Beerens, H. (1990). An Elective and Selective Isolation Medium for Bifidobacterium spp. Letters in Applied Microbiology. 11, pp. 155-157.

Belize Agricultural Health Authority (2001). Belize agricultural health authority (food processing plants) (potable water) (minimum standards) regulations.

Bernhard, A.E. and Field, K.G. (2000). A PCR assay to discriminate human and ruminant feces on the basis of host differences in Bacteroides-Prevotella genes encoding 16S rRNA. Applied and Environmental Microbiology. 66, pp. 4571-4574.

Blanch, A.R., Belanche-Munoz, L., Bonjoch, X., Ebdon, J., Gantzer, C., Lucena, F. et al. (2006). Integrated analysis of established and novel microbial and chemical methods for microbial source tracking. Applied and Environmental Microbiology. 72, pp. 5915-5926.

Boehm, A.B., Van De Werfhorst, L.C., Griffith, J.F., Holden, P.A., Jay, J.A., Shanks, O.C. et al. (2013). Performance of fortyone microbial source tracking methods: a twenty-seven lab evaluation study. Water Research. 47, pp. 6812-6828.

Boehm, A.B., Van De Werfhorst, L.C., Griffith, J.F., Holden, P.A., Jay, J.A., Shanks, O.C. et al. (2013). Performance of fortyone microbial source tracking methods: a twenty-seven lab evaluation study. Water Research. 15, pp. 18.

Bonjoch, X., Balleste, E. and Blanch, A.R. (2004). Multiplex PCR with 16S rRNA gene-targeted primers of bifidobacterium spp. to identify sources of fecal pollution. Applied and Environmental Microbiology. 70, pp. 3171-3175.

Boutilier, L., Jamieson, R., Gordon, R., Lake, C. and Hart, W. (2009). Adsorption, sedimentation, and inactivation of E. coli within wastewater treatment wetlands. Water Research. 43, pp. 4370-4380. doi: 10.1016/j.watres.2009.06.039.

Brazilian Ministry of Health (1990). Norms and Standards for Potable Water Destined for Human Consumption.

Brazilian Ministry of Health,. (1976). Classifying domestic water courses in order to protect their quality.

Bustin, S. (2006). Quantification of Nucleic Acids by PCR. A-Z of Quantitative PCR. (Bustin, S., ed.). International University Line. La Jolla, CA. pp. 3-29.

Chern, E.C., Brenner, K.P., Wymer, L.J. and Haugland, R.A. (2009). Comparison of Fecal Indicator Bacteria Densities in Marine Recreational Waters by qPCR. Water Quality, Exposure and Health. 1, pp. 203-214.

Chidavaenzi, M., Bradley, M., Jere, M. and Nhandara, C. (2000). Pit latrine effluent infiltration into groundwater: the Epworth case study. Schriftenr Ver Wasser Boden Lufthyg. 105, pp. 171-177.

Chinese Environmental Protection Agency, NTSB (1996). National Standards of the People's Republic of China: Integrated Wastewater Discharge Standard.

Chuang, P., Trottier, S. and Murcott, S. (2011). Comparison and verification of four field-based microbiological tests: H2S test, Easygel (R), Colilert (R), Petrifilm (TM). Journal of Water, Sanitation and Hygiene for Development. 1, pp. 68-85. 
Cinque, K., Stevens, M.A., Roser, D.J., Ashbolt, N.J. and Leeming, R. (2004). Assessing the health implications of turbidity and suspended particles in protected catchments. Water Science and Technology. 50, pp. 205-210.

COFREPRIS (1994). Norma Oficial Mexicana NOM-127-SSA1-1994, Salud Ambiental, Agua para Uso y Consumo Humano Limites Permisibles de Calidad y Tratamientos a que debe Someterse el Agua para su Potabilización. Secretary of Health.

Colombian Ministry of Health (1998). Technical Norms for Potable Water Quality. Decree 475-1998.

CONACYT (2009). Norma Salvadoreña Obligatoria NSO 13.49.01:09. Agua, Aguas Residuales Descargadas a un Cuerpo Receptor, Acuerdo No. 249, Diario Oficial.

CONACYT (2009). Norma Salvadoreña Obligatoria NSO 13.07.01:08. Agua, Agua Potable (Segunda Actualización). Ministerio de Salud.

CONAGUA (1997). Norma Oficial Mexicana NOM-001-ECOL-1996, Que establece los límites máximos permisibles de contaminantes en las descargas de aguas residuales en aguas y bienes nacionales. Secretary of Health. Mexico City, Mexico.

Costa Rican Ministry of Health (1997). Regulations for Potable Water Quality.

Coyne, M.J. and Comstock, L.E. (2008). Niche-specific features of the intestinal bacteroidales. Journal of Bacteriology. 190, pp. 736-742.

De Angelis, M., Piccolo, M., Vannini, L., Siragusa, S., De Giacomo, A., Serrazzanetti, D.I. et al. (2013). Fecal microbiota and metabolome of children with autism and pervasive developmental disorder not otherwise specified. PLoS ONE. 8, pp. e76993.

Dick, L.K., Bernhard, A.E., Brodeur, T.J., Santo Domingo, J.W., Simpson, J.M., Walters, S.P. et al. (2005). Host distributions of uncultivated fecal Bacteroidales bacteria reveal genetic markers for fecal source identification. Applied and Environmental Microbiology. 71, pp. 3184-3191.

Dick, L.K. and Field, K.G. (2004). Rapid estimation of numbers of fecal Bacteroidetes by use of a quantitative PCR assay for 16S rRNA genes. Applied and Environmental Microbiology. 70, pp. 5695-5697.

Dick, L.K., Stelzer, E.A., Bertke, E.E., Fong, D.L. and Stoeckel, D.M. (2010). Relative decay of Bacteroidales microbial source tracking markers and cultivated Escherichia coli in freshwater microcosms. Applied and Environmental Microbiology. 76, pp. 3255-3262.

Edge, T.A., Khan, I.U., Bouchard, R., Hill, S., Locas, A., Moore, L. et al. (2013). Occurrence of waterborne pathogens and Escherichia coli at offshore drinking water intakes in lake Ontario. Applied and Environmental Microbiology. 19, pp. 5799-5813.

ERSAPS (1996). Normas técnicas de las descargas de aguas residuales a cuerpos receptores y alcantarillado sanitario, Secretary of Health.

Escherich, T. (1885). Die Darmbakterien des Neugeboren und Sauglings. Fortschritte der Medizin. pp. 515-522 and 547-554.

Feachem, R.G., Bradley, D.J., Garelick, H. and Mara, D.D. (1983). Sanitation and Disease: Health Aspects of Excreta and Wastewater Management. World Bank. John Wiley and Sons. New York.

Figueras, M.J., Polo, F., Inza, I. and Guarro, J. (1994). Poor Specificity of M-Endo and M-Fc Culture Media for the Enumeration of Coliform Bacteria in Sea-Water. Letters in Applied Microbiology. 19, pp. 446-450.

Fremaux, B., Gritzfeld, J., Boa, T. and Yost, C.K. (2009). Evaluation of host-specific Bacteroidales 16S rRNA gene markers as a complementary tool for detecting fecal pollution in a prairie watershed. Water Research. 43, pp. 4838-4849.

Geldreich, E.E. (1978). Bacterial populations and indicator concepts in feces, sewage, stormwater and solid wastes. 
Indicators of Viruses in Water and Foo. (Berg, G., ed.). Ann Arbor Science. Ann Arbor, Mi.

Gourmelon, M., Caprais, M.P., Mieszkin, S., Marti, R., Wery, N., Jardé, E. et al. (2010). Development of microbial and chemical MST tools to identify the origin of the faecal pollution in bathing and shellfish harvesting waters in France. Water Research. 44, pp. 4812-4824.

Gourmelon, M., Caprais, M.P., Segura, R., Le Mennec, C., Lozach, S., Piriou, J.Y. et al. (2007). Evaluation of two libraryindependent microbial source tracking methods to identify sources of fecal contamination in French estuaries. Applied and Environmental Microbiology. 73, pp. 4857-4866.

Government of Turkey,. (1988). Regulation for Water Pollution Control.

Graham, J.P. and Polizzotto, M.L. (2013). Pit latrines and their impacts on groundwater quality: a systematic review. Environmental Health Perspectives. 121, pp. 521-530.

Green, H.C., Dick, L.K., Gilpin, B., Samadpour, M. and Field, K.G. (2012). Genetic markers for rapid PCR-based identification of gull, Canada goose, duck, and chicken fecal contamination in water. Applied and Environmental Microbiology. 78, pp. 503-510.

Green, H.C., Haugland, R.A., Varma, M., Millen, H.T., Borchardt, M.A., Field, K.G. et al. (2014). Improved HF183 quantitative real-time PCR assay for characterization of human fecal pollution in ambient surface water samples. Applied and Environmental Microbiology. 80, pp. 3086-3094.

Green, H.C., Shanks, O.C., Sivaganesan, M., Haugland, R.A. and Field, K.G. (2011). Differential decay of human faecal Bacteroides in marine and freshwater. Environmental Microbiology. 13, pp. 3235-3249.

Guarner, F. and,. (2003). Gut flora in health and disease. Lancet. 361, pp. 512-519.

Gueimonde, M., Tölkkö, S., Korpimäki, T. and Salminen, S. (2004). New real-time quantitative PCR procedure for quantification of bifidobacteria in human fecal samples. Applied and Environmental Microbiology. 70, pp. 4165-4169.

Hacker, J. and Blum-Oehler, G. (2007). In appreciation of Theodor Escherich. Nature Reviews Microbiology. Nature Reviews Microbiology. 5, pp. 902.

Harwood, V.J., Brownell, M., Wang, S., Lepo, J., Ellender, R.D., Ajidahun, A. et al. (2009). Validation and field testing of library-independent microbial source tracking methods in the Gulf of Mexico. Water Research. 43, pp. 4812-4819. doi: 10.1016/j.watres.2009.06.029.

Harwood, V.J., Butler, J., Parrish, D. and Wagner, V. (1999). Isolation of fecal coliform bacteria from the diamondback terrapin (Malaclemys terrapin centrata). Applied and Environmental Microbiology. 65, pp. 865-867.

Harwood, V.J., Levine, A.D., Scott, T.M., Chivukula, V., Lukasik, J.,, et al. (2005). Validity of the indicator organism paradigm for pathogen reduction in reclaimed water and public health protection. Applied and Environmental Microbiology. 71, pp. 3163-3170.

Harwood, V.J., Levine, A.D., Scott, T.M., Chivukula, V., Lukasik, J.,, et al. (2005). Validity of the indicator organism paradigm for pathogen reduction in reclaimed water and public health protection. Applied and Environmental Microbiology. 71, pp. 3163-3170.

Harwood, V.J., Staley, C., Badgley, B.D., Borges, K. and Korajkic, A. (2014). Microbial source tracking markers for detection of fecal contamination in environmental waters: relationships between pathogens and human health outcomes. FEMS Microbiology Reviews. 38, pp. 1-40.

Haugland, R.A., Varma, M., Sivaganesan, M., Kelty, C., Peed, L. and Shanks, O.C. (2010). Evaluation of genetic markers from the 16S rRNA gene V2 region for use in quantitative detection of selected Bacteroidales species and human fecal waste by qPCR. Systematic and Applied Microbiology. 33, pp. 348-357.

Haugland, R.A., Varma, M., Sivaganesan, M., Kelty, C., Peed, L. and Shanks, O.C. (2010). Evaluation of genetic markers 
from the 16S rRNA gene V2 region for use in quantitative detection of selected Bacteroidales species and human fecal waste by qPCR. Systematic and Applied Microbiology. 33, pp. 348-357.

A Heuval, V., McDermott, C., Pillsbury, R., Sandrin, T., Kinzelman, J., Ferguson, J. et al. (2010). The green alga, Cladophora, promotes Escherichia coli growth and contamination of recreational waters in Lake Michigan. Journal of Environmental Quality. 39, pp. 333-344.

Hill, R.T., Straube, W.L., Palmisano, A.C., Gibson, S.L. and Colwell, R.R. (1996). Distribution of sewage indicated by Clostridium perfringens at a deep-water disposal site after cessation of sewage disposal. Applied and Environmental Microbiology. 62, pp. 1741-1746.

Hoglund, C., Stenström, T.A., Jönsson, H. and Sundin, A. (1998). Evaluation of faecal contamination and microbial die-off in urine separating sewage systems. Water Science and Technology. 38, pp. 17-25.

Honduran Ministry of Health (1995). Technical Norm for the Quality of Potable Water.

Howell, J.M., Coyne, M.S. and Cornelius, P.L. (1996). Effect of sediment particle size and temperature on fecal bacteria mortality rates and the fecal coliform/fecal streptococci ratio. Journal of Environmental Quality. 25, pp. 1216-1220.

IBNORCA (2016). Calidad de agua potable para consumo humano.

IEOS (1992). Norms for the Study and Design of Potable Water Systems and the Deposition of Wastewater for Populations Greater than 1000 Inhabitants. Instituto Ecuatoriano de Obras Sanitarias.

Instittuto Nacional de Normalizacion (INN) (1984). Norma Chilena Oficial 409/1.Of.84. Drinking Water - Part 1: Requirements.

International AOAC (1995). Official Methods of AOAC International, 16th Edition, Volume I, Chapter 17. Association of Offical Analytical Chemists International. Gaithersburg, MD.

International ASTM (2000). Annual Book of ASTM Standards- Water and Environmental Technology. Section 11.02. ASTM International. West Conshohocken, PA.

ISO (2014). Water quality - Enumeration of Escherichia coli and coliform bacteria - Part 1: Membrane filtration method for waters with low bacterial background flora. International Standardization Organization. Geneva, Switzerland.

ISO (2012). Water Quality-Enumeration of Escherichia coli and coliform bacteria- Part 2: Most probable number method. International Standardization Organization. Geneva, Switzerland.

ISO (2000). Detection and enumeration of Escherichia coli and coliform bacteria - Part 1: Membrane filtration method. International Standardization Organization. Geneva, Switzerland.

ISO (1998). Detection and enumeration of Escherichia coli and coliform bacteria - Part3: Miniaturized method (most probable number) for the detection of $E$. coli in surface and wastewater. International Standardization Organization. Geneva, Switzerland.

ISO (1986). Detection and enumeration of the spores of sulfite-reducing anaerobes (clostridia) - Part 2: Method by membrane filtration. International Standardization Organization. Geneva, Switzerland.

ISO (1986). Detection and enumeration of the spores of sulfite-reducing anaerobes (clostridia) - Part 1: Method by enrichment in a liquid medium. International Standardization Organization. Geneva, Switzerland.

Israeli Ministry of Health (1991). Regulations Concerning the Sanitary Quality of Drinking Water.

Japan Environment Agency (1986). Environmental quality standards regarding water pollution No. 59, amended by Environment Agency Notification No. 63 of 1974, no. 3 of 1975, No. 41 of 1982, No. 140 of 1982, No. 29 of 1985 and No. 1 of 1986. 
Jeanneau, L., Solecki, O., Wery, N., Jardé, E., Gourmelon, M., Communal, P.Y. et al. (2012). Relative decay of fecal indicator bacteria and human-associated markers: a microcosm study simulating wastewater input into seawater and freshwater. Environmental Science and Technology. 46, pp. 2375-2382.

Johnston, C., Ufnar, J.A., Griffith, J.F., Gooch, J.A. and Stewart, J.R. (2010). A real-time qPCR assay for the detection of the nifH gene of Methanobrevibacter smithii, a potential indicator of sewage pollution. Journal of Applied Microbiology. 109, pp. 1946-1956.

Johnston, M.A., Porter, D.E., Scott, G.I., Rhodes, W.E. and Webster, L.F. (2010). Isolation of faecal coliform bacteria from the American alligator (Alligator mississippiensis). Journal of Applied Microbiology. 108, pp. 965-973.

Kellogg, R.L., Lander, C.H., Moffitt, D.C. and Gollehon, N. (2000). Manure nutrients relative to the capacity of cropland and pastureland to assimilate nutrients. USDA. Washington DC.

Kenya, R.of (2006). Environmental Management and Coordination (Water Quality) Regulations.

Khachatryan, Z.A., Ktsoyan, Z.A., Manukyan, G.P., Kelly, D., Ghazaryan, K.A. and Aminov, R.I. (2008). Predominant role of host genetics in controlling the composition of gut microbiota. PLoS One. 3, pp. e3064.

Kildare, B.J., Leutenegger, C.M., McSwain, B.S., Bambic, D.G., Rajal, V.B. and Wuertz, S. (2007). 16S rRNA-based assays for quantitative detection of universal, human-, cow-, and dog-specific fecal Bacteroidales: a Bayesian approach. Water Research. 41, pp. 3701-3715.

Korajkic, A., Badgley, B.D., Brownell, M.J. and Harwood, V.J. (2009). Application of microbial source tracking methods in a Gulf of Mexico field setting. Journal of Applied Microbiology. 107, pp. 1518-1527.

Korajkic, A., McMinn, B.R., Shanks, O.C., Sivaganesan, M., Fout, G.S. and Ashbolt, N.J. (2014). Biotic interactions and sunlight affect persistence of fecal indicator bacteria and microbial source tracking genetic markers in the upper Mississippi river. Applied and Environmental Microbiology. 80, pp. 3952-3961.

Korajkic, A., McMinn, B.R., Harwood, V.J., Shanks, O.C., Fout, G.S. and Ashbolt, N.J. (2013). Differential Decay of Enterococci and Escherichia coli Originating from Two Fecal Pollution Sources. Applied and Environmental Microbiology. 79, pp. 2488-2492. doi: 10.1128/AEM.03781-12.

Korajkic, A., McMinn, B.R., Shanks, O.C., Sivaganesan, M., Fout, G.S. and Ashbolt, N.J. (2014). Biotic Interactions and Sunlight Affect Persistence of Fecal Indicator Bacteria and Microbial Source Tracking Genetic Markers in the Upper Mississippi River. Applied and Environmental Microbiology. 80, pp. 3952-3961. doi: 10.1128/AEM.00388-14.

Korajkic, A., Wanjugi, P. and Harwood, V.J. (2013). Indigenous Microbiota and Habitat Influence Escherichia coli Survival More than Sunlight in Simulated Aquatic Environments. Applied and Environmental Microbiology. 79, pp. 5329-5337. doi: 10.1128/AEM.01362-13.

Korajkic, A., McMinn, B.R., Shanks, O.C., Sivaganesan, M., G Fout, S. and Ashbolt, N.J. (2014). Biotic interactions and sunlight affect persistence of fecal indicator bacteria and microbial source tracking genetic markers in the upper mississippi river. Applied and Environmental Microbiology. 80, pp. 3952-3961. doi: 10.1128/AEM.00388-14.

Kreader, C.A. (1998). Persistence of PCR-detectable Bacteroides distasonis from human feces in river water. Applied and Environmental Microbiology. 64, pp. 4103-4105.

Lamendella, R., Santo Domingo, J.W., Yannarell, A.C., Ghosh, S., Di Giovanni, G., Mackie, R.I. et al. (2009). Evaluation of swine-specific PCR assays used for fecal source tracking and analysis of molecular diversity of swine-specific "bacteroidales" populations. Applied and Environmental Microbiology. 75, pp. 5787-5796.

Langendijk, P.S., Schut, F., Jansen, G.J., Raangs, G.C., Kamphuis, G.R., Wilkinson, M.H. et al. (1995). Quantitative fluorescence in situ hybridization of Bifidobacterium spp. with genus-specific 16S rRNA-targeted probes and its application in fecal samples. Applied and Environmental Microbiology. 61, pp. 3069-3075.

Larsen, N., Vogensen, F.K., van den Berg, F.W., Nielsen, D.S., Andreasen, A.S., Pedersen, B.K. et al. (2010). Gut microbiota 
in human adults with type 2 diabetes differs from non-diabetic adults. PLoS ONE. 5, pp. e9085.

Layton, B.A., Cao, Y., Ebentier, D.L., Hanley, K., Balleste, E., Brandao, J. et al. (2013). Performance of human fecal anaerobe-associated PCR-based assays in a multi-laboratory method evaluation study. Water Research. 47, pp. 6897-6908.

Layton, B.A., Walters, S.P. and Boehm, A.B. (2009). Distribution and diversity of the enterococcal surface protein (esp) gene in animal hosts and the Pacific coast environment. Journal of Applied Microbiology. 106, pp. 1521-1531.

Levine, M.M. (1987). Escherichia coli that cause diarrhea: enterotoxigenic, enteropathogenic, enteroinvasive, enterohemorrhagic, and enteroadherent. The Journal of Infectious Diseases. 155, pp. 377-389.

Ludwig, W. and Schleifer, K.H. (2000). How quantitative is quantitative PCR with respect to cell counts?. Systematic and Applied Microbiology. 23, pp. 556-562.

Luyt, C.D., Tandlich, R., Muller, W.K. and Wilhelmi, B.S. (2012). Microbial monitoring of surface water in South Africa: an overview. International Journal of Environmental Research and Public Health. 9, pp. 2669-2693.

Madigan, M.T. and Martinko, J.M. (2006). Brock Biology of Microorhanisms 11th edition. Pearson. Upper Saddle, NJ.

Mara, D.D. and Oragui, J.I. (1983). Sorbitol-fermenting bifidobacteria as specific indicators of human faecal pollution. Journal of Applied Bacteriology. 55, pp. 349-357.

Masago, Y., Pope, J.M., Kumar, L.S., Masago, A., Omura, T. and Rose, J.B. (2011). Prevalence and Survival of Enterococcus faecium Populations Carrying the esp Gene as a Source-Tracking Marker. Journal of Environmental Engineering. 137(5), pp. 315-321.

Matsuki, T., Watanabe, K., Tanaka, R., Fukuda, M. and Oyaizu, H. (1999). Distribution of bifidobacterial species in human intestinal microflora examined with 16S rRNA-gene-targeted species-specific primers. Applied and Environmental Microbiology. 65, pp. 4506-4512.

McLellan, S.L. and Eren, A.M. (2014). Discovering new indicators of fecal pollution. Trends in Microbiology. 22, pp. 697-706.

McQuaig, S.M., Scott, T.M., Lukasik, J.O., Paul, J.H. and Harwood, V.J. (2009). Quantification of human polyomaviruses JC Virus and BK Virus by TaqMan quantitative PCR and comparison to other water quality indicators in water and fecal samples. Applied and Environmental Microbiology. 75, pp. 3379-3388.

Meays, C.L., Broersma, K., Nordin, R. and Mazumder, A. (2004). Source tracking fecal bacteria in water: a critical review of current methods. Journal of Environmental Management. 73, pp. 71-79.

Mieszkin, S., Furet, J.P., Corthier, G. and Gourmelon, M. (2009). Estimation of pig fecal contamination in a river catchment by real-time PCR using two pig-specific Bacteroidales 16S rRNA genetic markers. Applied and Environmental Microbiology. 75, pp. 3045-3054.

Mieszkin, S., Yala, J.F., Joubrel, R. and Gourmelon, M. (2010). Phylogenetic analysis of Bacteroidales 16S rRNA gene sequences from human and animal effluents and assessment of ruminant faecal pollution by real-time PCR. Journal of Applied Microbiology. 108, pp. 974-984.

Mieszkin, S., Yala, J.F., Joubrel, R. and Gourmelon, M. (2010). Phylogenetic analysis of Bacteroidales 16S rRNA gene sequences from human and animal effluents and assessment of ruminant faecal pollution by real-time PCR. Journal of Applied Microbiology. 108, pp. 974-984.

Miller, T.L., Weaver, G.A. and Wolin, M.J. (1984). Methanogens and anaerobes in a colon segment isolated from the normal fecal stream. Applied and Environmental Microbiology. 48, pp. 449-450.

MMAyA (1992). Reglamentacion de la Ley No. 1333 del Medioambiente. Gaceta Oficial de Bolivia.

Morrison, C.R., Bachoon, D.S. and Gates, K.W. (2008). Quantification of enterococci and bifidobacteria in Georgia estuaries 
using conventional and molecular methods. Water Research. 42, pp. 4001-4009.

Munoa, F.J. and R, P. (1988). Selective medium for isolation and enumeration of Bifidobacterium spp. Applied and Environmental Microbiology. 54, pp. 1715-1718.

Murray, B.E. (1990). The life and times of the Enterococcus. Clinical Microbiology Reviews. 3, pp. 46-65.

Neave, M., Luter, H., Padovan, A., Townsend, S., Schobben, X. and Gibb, K. (2014). Multiple approaches to microbial source tracking in tropical northern Australia. MicrobiologyOpen. 3, pp. 860-874.

Nebra, Y. and Blanch, A.R. (1999). A new selective medium for Bifidobacterium spp. Applied and Environmental Microbiology. 65, pp. 5173-5176.

Nguyen, M.T., Jasper, J.T., Boehm, A.B. and Nelson, K.L. (2015). Sunlight inactivation of fecal indicator bacteria in openwater unit process treatment wetlands: Modeling endogenous and exogenous inactivation rates. Water Research. 83, pp. 282-292. doi: 10.1016/j.watres.2015.06.043.

Noble, R.T., Blackwood, A.D., Griffith, J.F., McGee, C.D. and Weisberg, S.B. (2010). Comparison of rapid quantitative PCRbased and conventional culture-based methods for enumeration of Enterococcus spp. and Escherichia coli in recreational waters. Applied and Environmental Microbiology. 76, pp. 7437-7443.

Odagiri, M., Schriewer, A., Hanley, K., Wuertz, S., Misra, P.R., Panigrahi, P. et al. (2015). Validation of Bacteroidales quantitative PCR assays targeting human and animal fecal contamination in the public and domestic domains in India. The Science of the Total Environmental Microbiology. 502, pp. 462-470.

Ohad, S., Vaizel-Ohayon, D., Rom, M., Guttman, J., Berger, D., Kravitz, V. et al. (2015). Microbial Source Tracking in Adjacent Karst Springs. Applied and Environmental Microbiology. 81, pp. 5037-5047.

Okabe, S. and Shimazu, Y. (2007). Persistence of host-specific Bacteroides-Prevotella 16S rRNA genetic markers in environmental waters: effects of temperature and salinity. Applied Microbiology and Biotechnology. 75, pp. 935-944.

Oliveira, S.C. and von Sperling, M. (2011). Performance evaluation of different wastewater treatment technologies operating in a developing country. Journal of Water, Sanitation and Hygiene for Development. 1, pp. 37-56. doi: 10.2166/washdev.2011.022.

Ottoson, J.R. (2009). Bifidobacterial survival in surface water and implications for microbial source tracking. Canadian Journal of Microbiology. 55, pp. 642-647.

Palau, R.of (1996). Marine and Fresh Water Quality Regulations and Public Water Supply System Regulations.

Papua New Guinea Consolidated Legislation (2006). Environment (Water Quality Criteria) Regulation.

Pillai, S.D., Meckes, M.C., Murthy, S.N. and Willis, J. (2011). Developing Better Indicators for Pathogen Presence in Sewage Sludges. Water Intelligence.

Pisciotta, J.M., Rath, D.F., Stanek, P.A., Flanery, D.M. and Harwood, V.J. (2002). Marine bacteria cause false-positive results in the Colilert-18 rapid identification test for Escherichia coli in Florida waters. Applied and Environmental Microbiology. 68, pp. 539-544.

Raith, M.R., Kelty, C.A., Griffith, J.F., Schriewer, A., Wuertz, S., Mieszkin, S. et al. (2013). Comparison of PCR and quantitative real-time PCR methods for the characterization of ruminant and cattle fecal pollution sources. Water Research. 47, pp. 6921-6928.

Reischer, G.H., Ebdon, J.E., Bauer, J.M., Schuster, N., Ahmed, W., Astrom, J. et al. (2013). Performance Characteristics of qPCR Assays Targeting Human- and Ruminant-Associated Bacteroidetes for Microbial Source Tracking across Sixteen Countries on Six Continents. Environmental Science and Technology. doi: https://doi.org/10.1021/es304367t.

Reischer, G.H., Kasper, D.C., Steinborn, R., Farnleitner, A.H. and Mach, R.L. (2007). A quantitative real-time PCR assay for 
the highly sensitive and specific detection of human faecal influence in spring water from a large alpine catchment area. Letters in Applied Microbiology. 44, pp. 351-356.

Reischer, G.H., Kasper, D.C., Steinborn, R., Mach, R.L. and Famleitner, A.H. (2006). Quantitative PCR method for sensitive detection of ruminant fecal pollution in freshwater and evaluation of this method in alpine karstic regions. Applied and Environmental Microbiology. 72, pp. 5610-5614.

Republic of the Marshall Islands Environmental Protection Authority (1992). Marine Water Quality Regulations.

Resnick, I.G. and Levin, M.A. (1981). Quantitative procedure for enumeration of bifidobacteria. Applied and Environmental Microbiology. 42, pp. 427-432.

Ridley, C.M., Jamieson, R.C., L Hansen, T., Yost, C.K. and Bezanson, G.S. (2014). Baseline and storm event monitoring of Bacteroidales marker concentrations and enteric pathogen presence in a rural Canadian watershed. Water Research. 60, pp. 278-288.

Rose, J.B., Farrah, S.R., Harwood, V.J., Levine, A., Lukasik, J., Menendez, P. et al. (2004). Reduction of pathogens, indicator bacteria, and alternative indicators by wastewater treatment and reclamation processes. Water Science and Technology: Water Supply. Water Environmental Research Foundation (WERF), Final Report No. 00-PUM-2T.

Ryu, H., Elk, M., Khan, I.U., Harwood, V.J., Molina, M., Edge, T.A. et al. (2014). Comparison of two poultry litter qPCR assays targeting the 16S rRNA gene of Brevibacterium sp. Water Research. 48, pp. 613-621.

Ryu, H., Griffith, J.F., Khan, I.U., Hill, S., Edge, T.A., Toledo-Hernandez, C. et al. (2012). Comparison of gull feces-specific assays targeting the 16S rRNA genes of Catellicoccus marimammalium and Streptococcus spp. Applied and Environmental Microbiology. 78, pp. 1909-1916.

Sandowsky, M.J. and Whitman, R.L. (2011). The Fecal Bacteria. (Sandowsky, M.J. and Whitman, R.L., ed.). ASM Press. Washington DC.

Sassoubre, L.M., Nelson, K.L. and Boehm, A.B. (2012). Mechanisms for photoinactivation of Enterococcus faecalis in seawater. Applied and Environmental Microbiology. 78, pp. 7776-7785.

Sato, N., Okubo, T., Onodera, T., Ohashi, A. and Harada, H. (2006). Prospects for a self-sustainable sewage treatment system: A case study on full-scale UASB system in India's Yamuna River Basin. Journal of Environmental Management. 80, Elsevier. pp. 198-207.

Savichtcheva, O., Okyama, N. and Okabe, S. (2007). Relationships between Bacteroides $16 \mathrm{~S}$ rRNA genetic markers and presence of bacterial enteric pathogens and conventional fecal indicators. Water Research. 41, pp. 3615-3628.

Schönning, C., Leeming, R. and Stenström, T.A. (2002). Faecal contamination of source-separated human urine based on the content of faecal sterols. Water Research. 36, pp. 1965-1972.

Schulz, C.J. and Childers, G.W. (2011). Fecal bacteroidales diversity and decay in response to variations in temperature and salinity. Applied and Environmental Microbiology. 77, pp. 2563-2572.

Scott, T.M., Jenkins, T.M., Lukasik, J. and Rose, J.B. (2005). Potential use of a host associated molecular marker in Enterococcus faecium as an index of human fecal pollution. Environmental Science and Technology. 39, pp. 283-287.

Seurinck, S., Defoirdt, T., Verstraete, W. and Siciliano, S.D. (2005). Detection and quantification of the human-specific HF183 Bacteroides 16S rRNA genetic marker with real-time PCR for assessment of human faecal pollution in freshwater. Environmental Microbiology. 7, pp. 249-259.

Shanks, O.C., Atikovic, E., Blackwood, A.D., Lu, J., Noble, R.T., Domingo, J.S. et al. (2008). Quantitative PCR for detection and enumeration of genetic markers of bovine fecal pollution. Applied and Environmental Microbiology. 74, pp. 745-752.

Shanks, O.C., Kelty, C.A., Oshiro, R., Haugland, R.A., Madi, T., Brooks, L. et al. (2016). Data Acceptance Criteria for Standardized Human-Associated Fecal Source Identification Quantitative Real-Time PCR Methods. Environmental 
Microbiology. 82, pp. 2773-2782.

Shanks, O.C., Kelty, C.A., Sivaganesan, M., Varma, M. and Haugland, R.A. (2009). Quantitative PCR for genetic markers of human fecal pollution. Applied and Environmental Microbiology. 75, pp. 5507-5513.

Shanks, O.C., Santo Domingo, J.W., Lamendella, R., Kelty, C.A. and Graham, J.E. (2006). Competitive metagenomic DNA hybridization identifies host-specific microbial genetic markers in cow fecal samples. Applied and Environmental Microbiology. 72, pp. 4054-4060.

Shanks, O.C., Sivaganesan, M., Peed, L., Kelty, C.A., Blackwood, A.D., Greene, M.R. et al. (2012). Interlaboratory comparison of real-time PCR protocols for quantification of general fecal indicator bacteria. Environmental Science and Technology. 46, pp. 945-953.

Shanks, O.C., White, K., Kelty, C.A., Hayes, S., Sivaganesan, M., Jenkins, M. et al. (2010). Performance assessment PCRbased assays targeting bacteroidales genetic markers of bovine fecal pollution. Applied and Environmental Microbiology. 76, pp. 1359-1366.

Sidhu, J.P. and Toze, S.G. (2009). Human pathogens and their indicators in biosolids: a literature review. Environment International. 35, pp. 187-201.

Silkie, S.S. and Nelson, K.L. (2009). Concentrations of host-specific and generic fecal markers measured by quantitative PCR in raw sewage and fresh animal feces. Water Research. 43, pp. 4860-4871.

Singapore National Environment Agency (2008). Environmental Public Health (Quality of Piped Drinking Water) Regulations. Chapter 95 of the Environmental Public Health Act.

Sivaganesan, M., Haugland, R.A., Chern, E.C. and Shanks, O.C. (2010). Improved strategies and optimization of calibration models for real-time PCR absolute quantification. Water Research. 44, pp. 4726-4735.

Snyder, L. and Champness, W. (1997). Genes in Practice. Molecular Genetics of Bacteria. ASM Press. Washington DC, USA. pp. 418-419.

Sokolova, E., Astrom, J., Pettersson, JR, T., Bergstedt, O. and Hermansson, M. (2012). Decay of Bacteroidales genetic markers in relation to traditional fecal indicators for water quality modeling of drinking water sources. Environmental Science and Technology. 46, pp. 892-900.

Soller, J., Schoen, M., Varghese, A., Ichida, A., Boehm, A., Eftim, S. et al. (2014). Human health risk implications of multiple sources of faecal indicator bacteria in a recreational waterbody. Water Research. 66, pp. 254-264.

Soller, J.A., Schoen, M.E., Bartrand, T., Ravenscroft, J.E. and Ashbolt, N.J. (2010). Estimated human health risks from exposure to recreational waters impacted by human and non-human sources of faecal contamination. Water Research. 44, pp. 4674-4691.

Solo-Gabriele, H.M., Wolfert, M.A., Desmarais, T.R. and Palmer, C.J. (2000). Sources of Escherichia coli in a coastal subtropical environment. Applied and Environmental Microbiology. 66, pp. 230-7.

Sousa, M., Torres, C., Barros, J., Somalo, S., Igrejas, G. and Poeta, P. (2011). Gilthead seabream (Sparus aurata) as carriers of SHV-12 and TEM-52 extended-spectrum beta-lactamases-containing Escherichia coli isolates. Foodborne Pathogens and Disease. 8, pp. 1139-1141.

Sri Lankan Ministry of Environment and Natural Resources (2008). National Environmental Act.

Srinivasan, S., Aslan, A., Xagoraraki, I., Alocilja, E. and Rose, J.B. (2011). Escherichia coli, enterococci, and Bacteroides thetaiotaomicron qPCR signals through wastewater and septage treatment. Water Research. 45, pp. 2561-2572.

Stauber, C., Miller, C., Cantrell, B. and Kroell, K. (2014). Evaluation of the compartment bag test for the detection of Escherichia coli in water. Journal of Microbiological Methods. 99, pp. 66-70. 
Stewart, J.R., Boehm, A.B., Dubinsky, E.A., Fong, T.T., Goodwin, K.D., Griffith, J.F. et al. (2013). Recommendations following a multi-laboratory comparison of microbial source tracking methods. Water Research. 47, pp. 6829-6838.

Surbeck, C.Q., Jiang, S.C. and Grant, S.B. (2010). Ecological control of fecal indicator bacteria in an urban stream. Environmental Science and Technology. 44, pp. 631-637.

Tambalo, D.D., Fremaux, B., Boa, T. and Yost, C.K. (2012). Persistence of host-associated Bacteroidales gene markers and their quantitative detection in an urban and agricultural mixed prairie watershed. Water Research. 46, pp. 2891-2904.

Tanzania Minister of State (2005). Regulations for the Environmental Management Act (Water Quality Standards).

Toledo-Hernandez, C., Ryu, H., Gonzalez-Nieves, J., Huertas, E., Toranzos, G.A. and Santo Domingo, J.W. (2013). Tracking the primary sources of fecal pollution in a tropical watershed in a one-year study. Applied and Environmental Microbiology. 79, pp. 1689-1696.

Ufnar, J.A., Wang, S.Y., Christiansen, J.M., Yampara-Iquise, H., Carson, C.A. and Ellender, R.D. (2006). Detection of the nifH gene of Methanobrevibacter smithii: a potential tool to identify sewage pollution in recreational waters. Journal of Applied Microbiology. 101, pp. 44-52.

United Kingdom (Northern Ireland) (2007). Water and Sewerage: The Water Supply (Water Quality) Regulations.

United Kingdom (Scotland) (2008). Environmental Protection, Water: The Bathing Waters Regulations.

United Kingdom (Scotland) (2001). Water Supply: The Water Supply (Water Quality) Regulations.

USEPA (2012). Recreational Water Quality Criteria. United States Environmental Protection Agency. Washington, DC.

USEPA (2006). National Primary Drinking Water Regulations: Revisions to the Total Coliform Rule; Regulations: Revisions to the Total Coliform Rule; Final Rule. 40 CFR Parts 141 and 142. Federal Register. United States Environmental Protection Agency. Washington, DC.

USEPA (2006). Method 1600: Enterococci in Water by Membrane Filtration Using membrane-Enterococcus Indoxyl\$lbeta\$-D-Glucoside Agar (mEI) EPA-821-R-06-009.

USEPA (2006). National Primary Drinking Water Regulations: Long-Term 2 Enhanced Surface Water Treatment Rule (LT2ESWTR); Final Rule. 40 CFR Parts 9, 141, 142. Federal Register. United States Environmental Protection Agency.

USEPA (2006). Method 1600: Enterococci in Water by Membrane Filtration Using membrane-Enterococcus Indoxyl\$lbeta\$-D-Glucoside Agar (mEI). United States Environmental Protection Agency. Washington, DC.

USEPA (2006). Method 1603: Escherichia coli (E. coli) in Water by Membrane Filtration Usinge Modified membraneThermotolerant Escherichia coli Agar (modified mTEC). United States Environmental Protection Agency. Washington, DC.

Van De Werfhorst, L.C., Sercu, B. and Holden, P.A. (2011). Comparison of the host specificities of two bacteroidales quantitative PCR assays used for tracking human fecal contamination. Applied and Environmental Microbiology. 77, pp. 6258-6260.

Vierheilig, J., Frick, C., Mayer, R.E., Kirschner, A.K.T., Reischer, G.H., Derx, J. et al. (2013). Clostridium perfringens is not suitable for the indication of fecal pollution from ruminant wildlife but is associated with excreta from nonherbivorous animals and human sewage. Applied and Environmental Microbiology. 79, pp. 5089-5092.

United Kingdom (England and Wales) (2013). Water Resources: The Bathing Water Regulations.

United Kingdom (England and Wales) (2010). Water, England and Wales: The Water Supply (Water Quality) Regulations.

Walters, S.P. and Field, K.G. (2009). Survival and persistence of human and ruminant-specific faecal Bacteroidales in freshwater microcosms. Environmental Microbiology. 11(6), pp. 1410-1421.

Wang, R.F., Cao, W.W. and Cerniglia, C.E. (1996). PCR detection and quantitation of predominant anaerobic bacteria in 
human and animal fecal samples. Applied and Environmental Microbiology. 62, pp. 1242-1247.

Wanjugi, P., Fox, G.A. and Harwood, V.J. (2016). The Interplay Between Predation, Competition, and Nutrient Levels Influences the Survival of Escherichia coli in Aquatic Environments. Microbial Ecology. 72, pp. 526-537.

Wanjugi, P. and Harwood, V.J. (2014). Protozoan predation is differentially affected by motility of enteric pathogens in water vs. sediments. Microbial Ecology. 68, pp. 751-760.

Wanjugi, P. and Harwood, V.J. (2013). The influence of predation and competition on the survival of commensal and pathogenic fecal bacteria in aquatic habitats. Environmental Microbiology. 15, pp. 517-526.

Weidhaas, J.L., Macbeth, T.W., Olsen, R.L., Sadowsky, M.J., Norat, D. and Harwood, V.J. (2010). Identification of a Brevibacterium marker gene specific to poultry litter and development of a quantitative PCR assay. Journal of Applied Microbiology. 109, pp. 334-347. doi: 10.1111/j.1365-2672.2010.04666.x.

Wexler, H.M. (2012). Pump it up: occurrence and regulation of multi-drug efflux pumps in Bacteroides fragilis. Anaerobe. 18, pp. 200-208.

WHO (2011). Guidelines for drinking water quality, 4th edition. World Health Organization.

WHO (2006). Guidelines for the safe use of wastewater, excreta and greywater. Volumes I-IV. World Health Organization.

Wilson, M. (2005). Microbial Inhabitants of Humans: Their Ecology and Role in Health and Disease. Cambridge University Press. Cambridge, UK.

Yampara-Iquise, H., Zheng, G., Jones, J.E. and Carson, C.A. (2008). Use of a Bacteroides thetaiotaomicron-specific alpha-1-6, mannanase quantitative PCR to detect human faecal pollution in water. Journal of Applied Microbiology. 105, pp. 1686-1693.

Zabalaga, J., Amy, G. and von Munch, E. (2007). Evaluation of agricultural reuse practices and relevant guidelines for the Alba Rancho WWTP (primary and secondary facultative ponds) in Cochabamba, Bolivia. Water Science and Technology. 55, pp. 469-475.

Zaleski, K.J., Josephson, K.L., Gerba, C.P. and Pepper, I.L. (2005). Potential Regrowth and Recolonization of Salmonellae and Indicators in Biosolids and Biosolid-Amended Soil. Applied and Environmental Microbiology. 71, pp. 3701-3708.

Zimmer, J., Lange, B., Frick, J.S., Sauer, H., Zimmermann, K., Schwiertz, A. et al. (2012). A vegan or vegetarian diet substantially alters the human colonic faecal microbiota. European Journal of Clinical Nutrition. 66, pp. 53-60. 